\title{
The Neolithic-Eneolithic sequence and pottery assemblages in the fifth millennium BC in north-eastern Slovenia
}

\author{
Bine Kramberger \\ Ljubljana, SI \\ bine.kramberger@siol.net
}

\begin{abstract}
This paper discusses the settlements at Andrenci, Stoperce, Ptuj-Šolski center, Zgornje Radvanje and Hoče-Orglarska delavnica, all located in north-eastern Slovenia. The settlements are dated on the basis of the results of radiocarbon analyses. The characteristics of the material and cultural-chronological site structures were studied through analyses of pottery (pottery production, form, decoration) and comparative analyses.
\end{abstract}

IZVLEČEK - V prispevku obravnavamo naselbine Andrenci, Stoperce, Ptuj-Šolski center, Zgornje Radvanje in Hoče-Orglarska delavnica, ki se nahajajo v severovzhodni Sloveniji. Na podlagi rezultatov radiokarbonskih analiz ugotavljamo starost naselbin. $Z$ analizami keramičnih najdb (način izdelave keramike, oblike, okras) in s primerjalnimi analizami pa smo raziskali značilnosti materialne kulture in kulturno-kronološko strukturiranost najdišč.

KEY WORDS - Neolithic; Eneolithic; settlement; NE Slovenia; $5^{\text {th }}$ millennium BC; pottery analysis; ${ }^{14} \mathrm{C}$ analysis; chronology

\section{Introduction}

The study of the Neolithic and Eneolithic periods in north-eastern Slovenia (for an overview of the earlier part of the history of research, see Budja 1983) does not have a long tradition, in comparison with neighbouring countries, and this area consequently lacks knowledge and archaeological research of this era. Mainly due to archaeological research on the motorway network, only archaeological periods after the second half of the $5^{\text {th }}$ millennium onwards in north-eastern Slovenia are relatively well-studied (i.e. the Lasinja Culture), while only individual pits, structures and finds from the end of the first half of the $5^{\text {th }}$ millennium are known, and older settlement have not even been identified to date. 1
The present research has therefore been focused on analyses of pottery and an assessment of selected north-eastern Slovenian settlements dating to the first and the second half of the $5^{\text {th }}$ millennium $\mathrm{BC}$. The settlements are located relatively close to one another, in an area which is also important in the interpretation of archaeological records elsewhere (primarily in Austria, Hungary and Croatia) due to its transitional location between the Alps and the Pannonian Plain. The settlement of Andrenci is located on a hill 335m high, called Andrenški vrh, in western Slovenske gorice. Stoperce is located in Haloze, along the Majšperk-Rogatec road, while Ptuj-Šolski center, Zgornje Radvanje and Hoče-Orglarska delavnica are

1 Bukovnica (̌̌avel 1992.59-60; 1994.47-48; 2006.90), Andrenci (for both see also Budja 1983.81; Guštin 2005.9-16; Tomaž 2010. 164; Kavur 2010.71; Velušček 2006.32-35; 2011.211-216), Ptuj-Šolski center, and partly, to a small extent, Ptujski grad (for both see Guštin 2005.Fig. 1; Tomaž 2010.164; Kavur 2010.Fig. 1), are sites that have been most often mentioned in literature as the only late Neolithic sites in north-eastern Slovenia. Most of the pottery from Ptuj-Šolski center has, until recently, not even been drawn or mended and, with the exception of Ptuj-Šolski center, no ${ }^{14} \mathrm{C}$ dates were available for these sites. 
situated on the edge of the Drava plain (Fig. 1).

\section{Settlement contexts}

\section{Andrenci}

Small-scale trenches dug in the 1950s at the settlement on Andrenški vrh partially explored two structures ( $\mathrm{Pa}$ hič, Lorber 1954; Pahič 1973; 1976).

Structure A was represented by a large pit containing two cultural layers, the bottom (A1) and top (A2). They both contained residue of charcoal, burnt clay, fragments of pottery vessels (A1: Pl. 1.1-9; see also Pahič 1976.Pl. 2; A2: Pl. 1.13-20; see also Pahič 1976.Pl. 3 - Pl. 4.24) and stone tools (A1: Pahič 1976.Pl. 1.2, 8, 16-18; A2: Pahič 1976.Pl. 1.3, $11-12), 2$ but they were delimited by a thinner layer, A2a, which in addition to individual pottery fragments (Pahic 1976.Pl. 4.25-27) and stone tools (Pahič 1976.Pl. 1.9) also contained charcoal, ash,

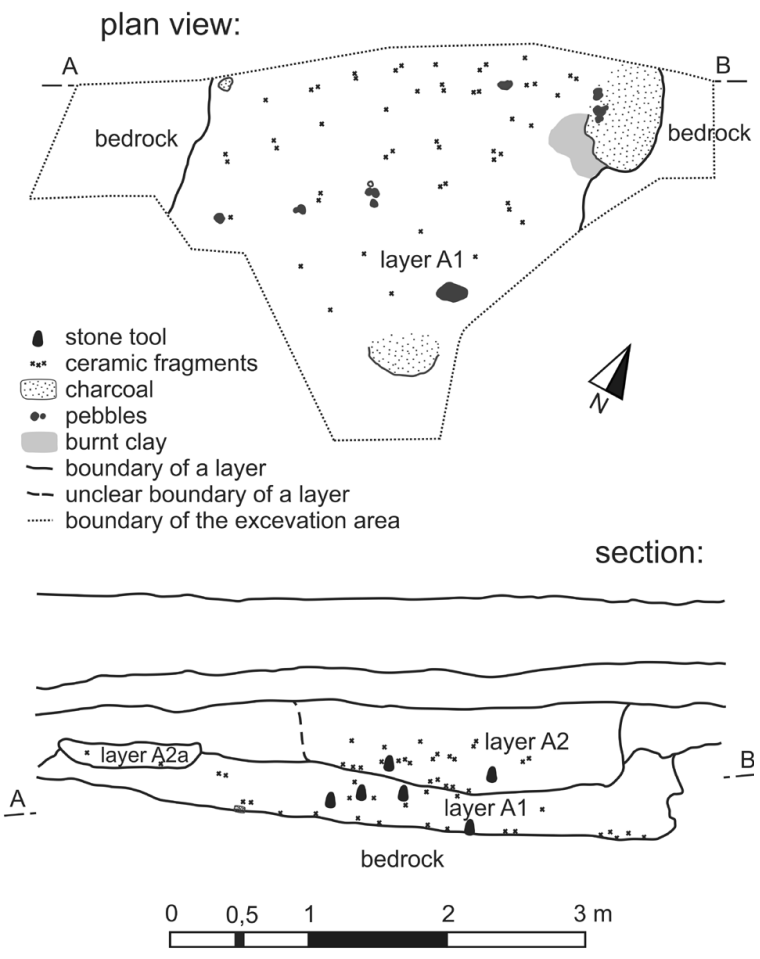

Fig. 2. Andrenci. Strucure A. Plan and section.

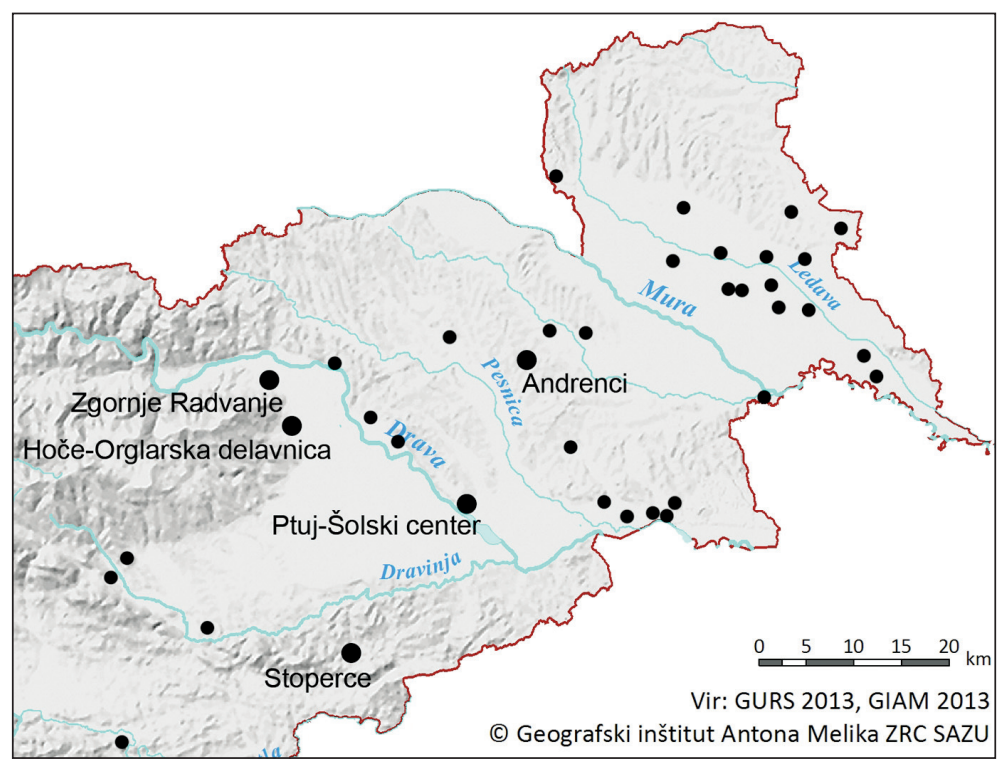

Fig. 1. Map of north-eastern Slovenian sites with settlement remains dating to the $5^{\text {th }}$ millennium BC. Larger dots and inscriptions mark settlements, which are analysed in this paper.

rare bones and two spindle whorls (Pahič 1976.Pl. 24.28-29) (Fig. 2). 3

Structure B also comprised a large pit with two cultural layers, bottom (B1) and top (B2). Both layers contained fragments of ceramic vessels (B1: Pl. 2.2534, B2: Pl. 2.35-51; see also Pahič 1976.Pl. 5.1-Pl. 22.6) and stone tools (Pahič 1976.Pl. 1.6-7, 13-15), and were delimited by charcoal. In the bottom layer, and partly under it (Pahič 1976.41), two straight lines of pebbles with their intersection forming a right angle were discovered, which may be interpreted as part of a wall or building foundation (Fig. 3).

The ${ }^{14} \mathrm{C}$ analysis of charred food residues obtained from the inner surface of a vessel base from the top layer (B2) in structure B showed a conventional age of $5730 \pm 40 \mathrm{BP}$, which means that it dates between 4689 and 4466 calBC (95.4\% probability) or (between) 4652 and 4505 calBC (68.2\% probability). Pottery assemblages from Andrenci are typologically homogeneous (Pls. 1-2), so it is possible to assume that both structures presented above were contemporaneous. 4

\section{Stoperce}

Based on the results of ${ }^{14} \mathrm{C}$ analyses, analyses of stratigraphic sequences and analyses of pottery, it is

2 Layer A1 also yielded two large concentrations of charcoal and burnt clay (Fig. 2), which might represent the remains of a structure or a hearth (see also Pahič 1976.35).

3 Parts of individual vessels were found in both layers (Pl. 1.13-20), while Structure A also yielded individual finds (Pahic, Lorber 1954.335-338) with unknown location details (Pl. 1.21-24).

4 The conventional value of all the dates presented in this paper was calibrated using the program 0xCal version v4.2.3 (Bronk Ramsey, Lee 2013), with a current calibration curve (Reimer et al. 2013). 


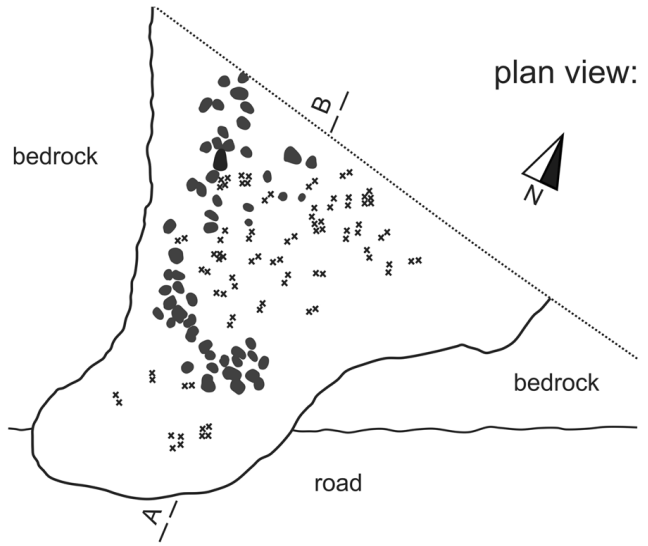

stone tool

$\times \times x$ ceramic fragments

- pebbles

- boundary of a layer

--. unclear boundary of a laye

....... boundary

of the excevation area

section:
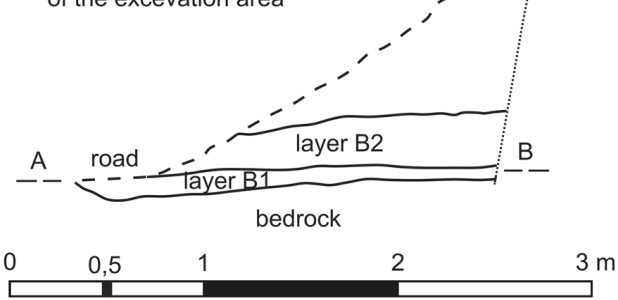

Fig. 3. Andrenci. Structure B. Plan and Section.

possible to conclude that the area researched in 2009 was settled twice (Fig. 6). The first (earlier) phase is represented by Structure I, and the second by Structure III - area 2. At least three (II, IV and V) other structures were discovered. They did not contain pits with pottery, and absolute dates were not obtained. However, it seems that they belong to the second settlement phase, because smaller pits (Pl. 4.75-77), ditches and post-holes were discovered in the vicinity which contained pottery comparable to pottery found in the pit from Structure III (compare with Pl. 4.70-74); fragments of such vessels were also found in a thin cultural layer, stratigraphic unit (SE) 003, which was examined in isolated areas on top of the structure remains.
Structure I was single-spaced, partially deepened (pit SE 128) and, based on the distribution of post-holes, probably had a trapezoidal floor plan. The hollow/ pit was filled with a single layer which contained charcoal, burnt clay, fragments of Late Neolithic pottery vessels (Pl. 3) and individual stone tools (Fig. 7). The ${ }^{14} \mathrm{C}$ measurements of charcoal sample Beta339594 , gained from this layer showed a conventional age of $5690 \pm 30 \mathrm{BP}$, which means that it dates to the end of the first half or the turn of the first to the second half of the $5^{\text {th }}$ millennium $\mathrm{BC}$, and that Structure I was contemporary with Structure B from Andrenci (Figs. 9-10).

Structure III, which represents the second settlement phase, was perhaps two-spaced. 5 Area 1 was not deepened, and rare pottery fragments were discovered only in a thin cultural layer above the postholes. The central part of Area 2 was some $30 \mathrm{~cm}$ deepened, with two cultural layers and a hearth detected in the pit itself (SE 150). The upper layer (layer 2) contained charcoal, burnt clay, a number of Early Eneolithic vessel fragments (Pl. 4.70-74) and stone tools. The bottom layer (layer 1) did not yield any finds. 6 The hearth was discovered in the specially formed north-eastern part of the pit SE 150 which appeared as a layer of charcoal $2 \mathrm{~cm}$ thick containing some burnt clay fragments (Fig. 8).

Two ${ }^{14} \mathrm{C}$ dates are available from pit SE 150 (Structure III - Area 2), which significantly differ: the first date was calibrated to the end of the $5^{\text {th }}$ and the beginning of the $4^{\text {th }}$ millennium BC (Beta-362539) and the second to the end of the first half of the $4^{\text {th }}$ millennium BC (Beta-339595). It is important to emphasise that the pottery from the pit is homogeneous, that comparable pottery occurs at sites within the region and beyond at the end of the $5^{\text {th }}$ and the beginning of the $4^{\text {th }}$ millennium $\mathrm{BC}$, and that pottery, or any other proof of dating to the end of the first half of the $4^{\text {th }}$ millennium $\mathrm{BC}$, was absent

\begin{tabular}{|lcccccccl|}
\hline Site & \multirow{2}{*}{ Context } & $\begin{array}{c}\text { Lab } \\
\text { Code }\end{array}$ & Material & $\begin{array}{c}\text { Age } \\
(\text { (BP) }\end{array}$ & $\begin{array}{c}\text { SD } \\
( \pm a)\end{array}$ & $\begin{array}{c}\text { CalBC } \\
(68.2 \%)\end{array}$ & $\begin{array}{c}\text { Cal BC } \\
(95.4 \%)\end{array}$ & Reference \\
\hline Andrenci & Structure B (B2) & Beta-339593 & food crust & 5730 & 40 & $4652-4505$ & $4689-4466$ & first published here \\
\hline
\end{tabular}

Figs. 4 and 5. Andrenci. Structure B, layer B2. ${ }^{14} \mathrm{C}$ AMS date.

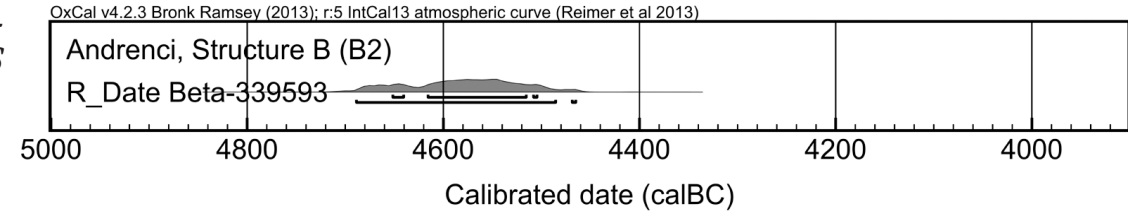

5 There is a possibility that areas 1 and 2 were actually two separate structures, where one was older than the other, or perhaps they co-existed, but no stratigraphic data exist.

6 Cultural layers were separated based on the differences in the colour and fragments of pottery, stone objects and charcoal which concentrated on the boundary between them. 


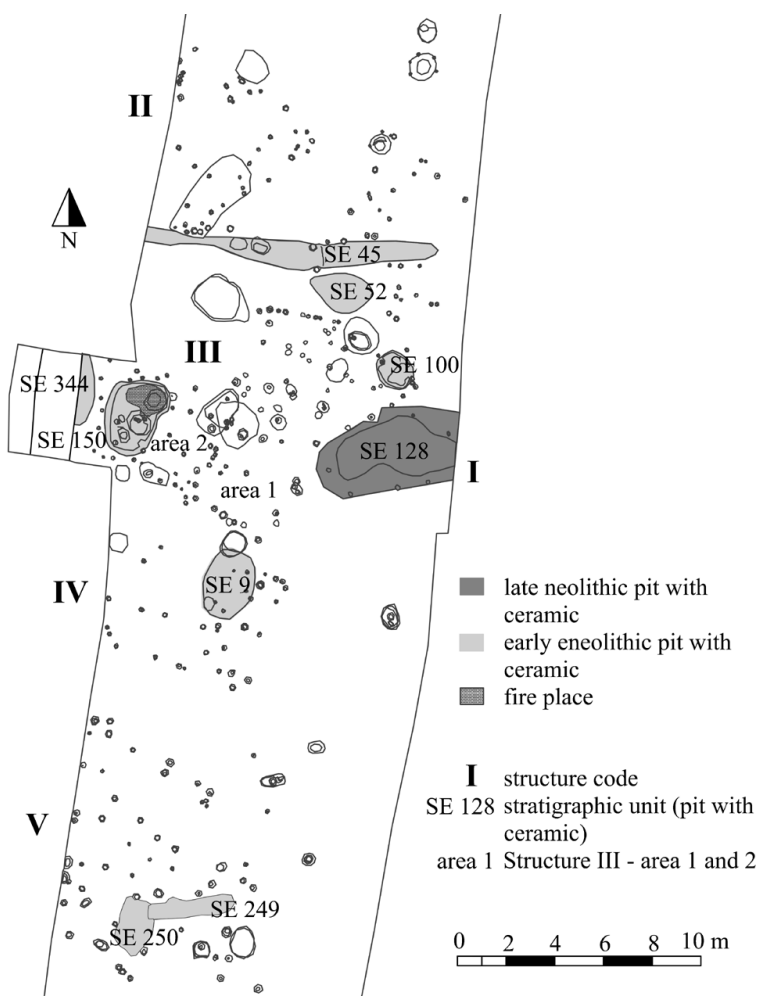

Fig. 6. Stoperce. General plan of the site.

from Stoperce. 7 Therefore, it is possible to assume that the date of Beta-339595 is too late for the presented context (Figs. 9-10).

\section{Ptuj-Šolski center}

During 1980/1981 (Structure I), 2000 (Structures II and III) and finally 2010 (Structure IV), this multiperiod site yielded four structures from the $5^{\text {th }}$ millennium BC (Strmčnik Gulič 1983; Lubšina Tušek 2004. 74). Structures II and IV have been radiocarbon dated and are presented in detail below.

Structure IV was deepened in the central part, where two cultural layers and a number of small pits were found (Fig. 11). Most of the pottery was found in layer SE 410, which was the top layer of a pit (Pl. 5.78-85), layer SE 430, which was located beneath (Pl. 5.89-91) and in a smaller pit SE 435, which was found at the deepest point of the structure. Parts of individual vessels were detected in all of the mentioned stratigraphic units (Pl. 5.86-88), so we can assume that all layers were deposited within a short time span. This can be partially confirmed by ${ }^{14} \mathrm{C}$ analyses of charcoal samples, which place Structure IV between the second half of the $45^{\text {th }}$ and $43^{\text {rd }}$ centuries BC (Figs. 13-14).

Structure II was probably rectangular. It was deepened along its entire length. The shallow deepening contained two cultural layers, a hearth and a greater concentration of burnt clay, probably the remains of a wall destroyed by fire. Two construction phases were documented, but they were more or less contemporary, as the northern and western sides of the building were only slightly modified during the second construction phase (Fig. 12). 8 The bottom layer, which yielded a few stone artefacts and a large number of pottery fragments (Pl. 6), was deposited between the two construction phases. The upper, yellowish brown layer was deposited after the second construction phase and contained less pottery.

Two ${ }^{14} \mathrm{C}$ dates are available to determine the age of Structure II; however, one of these is unreliable and

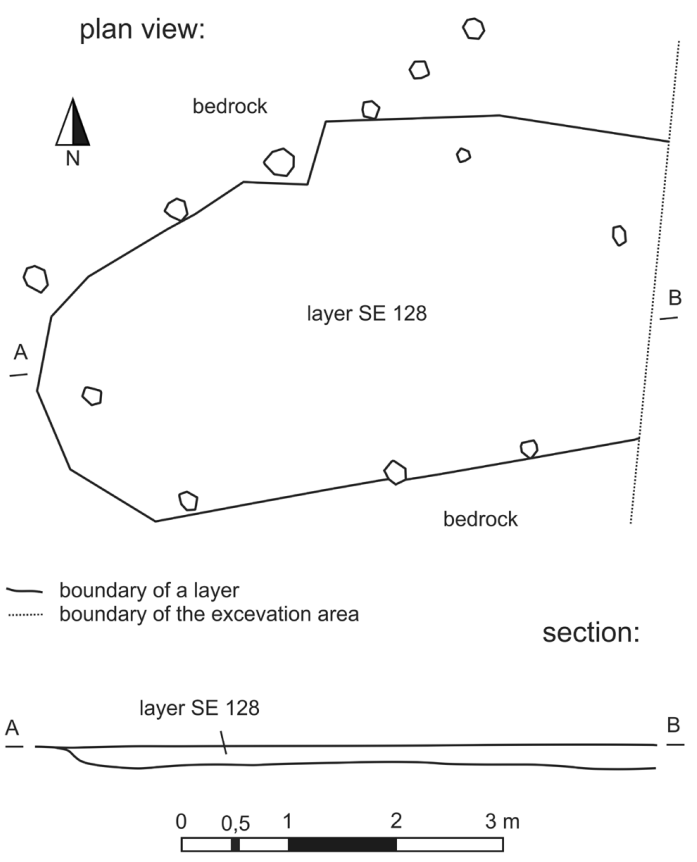

Fig. 7. Stoperce. Structure I. Plan and section.

\footnotetext{
7 In north-eastern Slovenia, pottery from the end of the first half of the $4^{\text {th }}$ millennium was discovered at ${ }^{14} \mathrm{C}$ dated settlements at Kalinovnjek near Turnišče (Kerman 2013a.242-245), Turnišče (Tomaž 2012.277-280), Gornje njive near Dolga vas (Kerman 2013b.407) and a ${ }^{14} \mathrm{C}$ dated graveyard Pod Kotom - jug near Krog (Šavel 2009.64, 94). The absolute date from pit SE 11 at Ivankovci in Lendava is more or less simultaneous to dates, mentiones above. The pit yielded very fragmented (!) vessels from the Early Eneolithic period (Kavur 2011.125-127) together with fragments that are believed to be later, from the end of the first half of the $4^{\text {th }}$ millennium BC (Kavur 2011.find nos. 31 and 101).

8 Construction phases were determined based on the heights of the post-holes. Individual post-holes were discovered at the base of the pit, while others were above the bottom layer.
} 
therefore was not included in further analyses. 9 The second available date places, with $68.2 \%$ probability, Structure II to the period between 4527-4366 calBC, which means that it may be slightly earlier than Structure IV. However, it has to be stressed that Structure II yielded one reliable ${ }^{14} \mathrm{C}$ date, while Structure IV offers three (Figs. 13-14).

\section{Zgornje Radvanje}

The area of the site was intermittently inhabited from the Eneolithic to the Early Modern Period (Kramberger 2010b.311; 2010a. 7; Murko 2012.141-142; Arh 2012). This paper presents 23 Eneolithic settlement structures, which were investigated in 2007 and 2008.10 The settlement was probably circular in form. Structure 22 was located in the central part in the first visible circumference, together with structures 31-36, which had not been deepened and yielded no finds. 11 The second circumference contained structures 5-21 and 26, with associated smaller pits; the third circumference was represented by structures 2-4, with associated smaller pits, while the partly researched fourth circumference might be represented by Structure 1 in the far north-eastern part of the excavation area and smaller pits SE 212, SE 245, SE 247 in the far western part (Fig. 15).

In addition to the structure studied already in complex 10 (Kramberger 2010b), labelled as Structure $5,14 \mathrm{C}$ dates were also obtained from structures 22, 1, 4, 6, 7 and 10. The size and form of Structure 22 is comparable to Structure 5. Furthermore, it contained two phases; both were ${ }^{14} \mathrm{C}$ dated (Fig. 16). Phase 1 was identified by several small pits containing

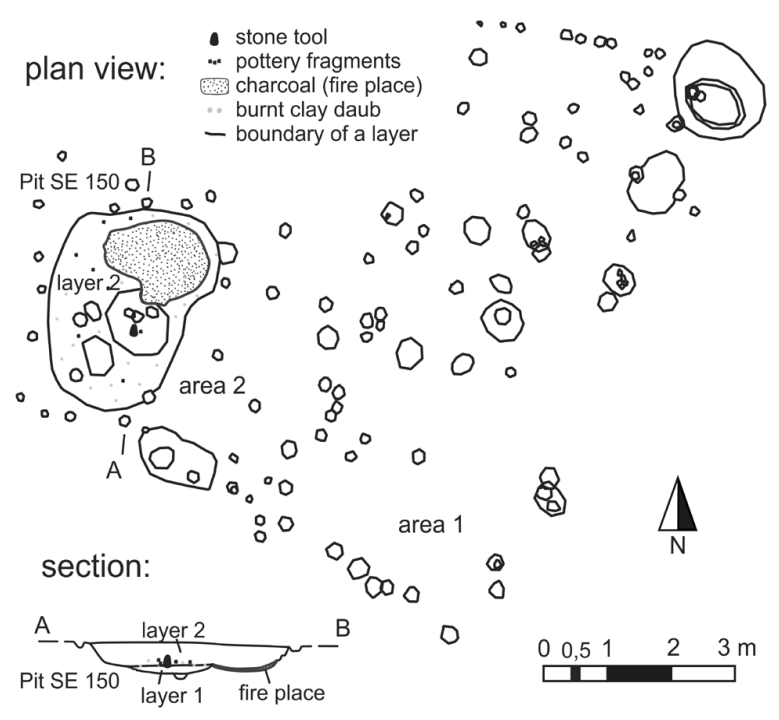

Fig. 8. Stoperce. Structure III with areas 1 and 2. Plan and section.

stone finds, pottery fragments (Pl. 7.109-118), fragments of burnt clay and wood, while Phase 2 was interpreted as the remains of a trapezoid house, ${ }^{12}$ which was located above the Phase 1 pits. The daily activities of Phase 2 were documented by the remains of a hearth, with pottery (Pl. 7.119-122) and stone finds.

Based on the position of the post-holes, structure 6 was rectangular (Fig. 17). In contrast to structures 5 and 22, a uniform cultural layer (SE 250 $=252=$ 226) has been detected in a shallow deepening, which was ${ }^{14} \mathrm{C}$ dated. It contained fragments of charcoal and burnt clay, individual stone tools and pottery fragments (Pl. 8.123-133).

\begin{tabular}{|c|c|c|c|c|c|c|c|c|}
\hline Site & Context & $\begin{array}{l}\text { Lab } \\
\text { Code }\end{array}$ & Material & $\begin{array}{l}\text { Age } \\
\text { (BP) }\end{array}$ & $\begin{array}{l}\text { SD } \\
( \pm a)\end{array}$ & $\begin{array}{c}\text { CalBC } \\
(68.2 \%)\end{array}$ & $\begin{array}{c}\text { Cal BC } \\
(95.4 \%)\end{array}$ & Reference \\
\hline Stoperce & Structure I (SE 128) & Beta-339594 & charcoal & 5690 & 30 & $4548-4466$ & $4604-4456$ & first published here \\
\hline Stoperce & Structure III (SE 150) & Beta-362539 & charcoal & 5200 & 30 & $4039-3971$ & $4047-3961$ & first published here \\
\hline Stoperce & Structure III (SE 150) & Beta-339595 & charcoal & 4820 & 30 & $3650-3536$ & $3656-3526$ & first published here \\
\hline
\end{tabular}

Figs. 9 and 10. Stoperce. First and second settlement phase. ${ }_{14} \mathrm{C}$ AMS date. The 'problematic' date, excluded from further analyses, is shown with inclined letters.

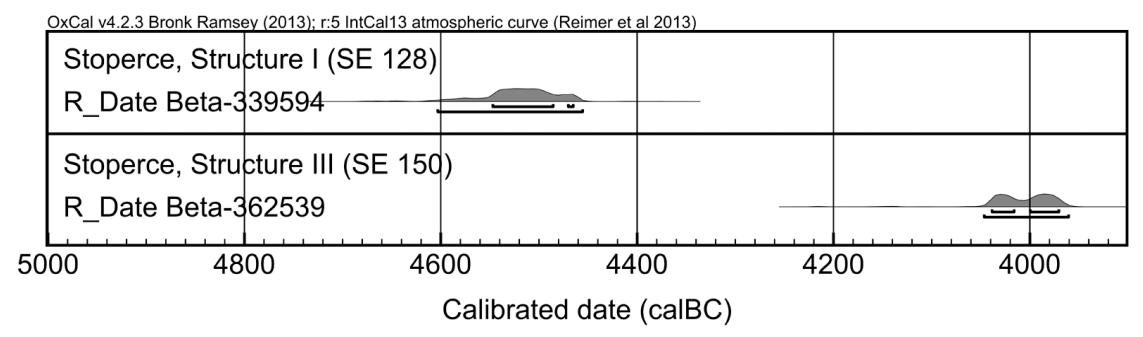

9 This is the date of sample Z-3015, which was created by combining five different samples of charcoal, which, as is generally known, strongly influences the results of ${ }^{14} \mathrm{C}$ analysis.

10 The rest of the settlement was studied by Monika Arh (2012).

11 Structures 31-36 have not yet been ${ }^{14} \mathrm{C}$ dated, but based on their position in the first circumference, they seem to be from the Early Eneolithic period.

12 A greater quantity of burnt plaster and charcoal has been documented just above small pits, but direct evidence of the existence of a wooden structure similar to Structure 5 (burnt wooden post) has not been found here (Kramberger 2010b.Fig. 4). 
Early Eneolithic Structure 4 was discovered under alluvial layer SE 983, which contained finds from the same period. Two layers were discovered in pit SE 1129. The pit base was filled with layer SE 1128. The ${ }^{14} \mathrm{C}$ dated layer SE 1102 was placed on top. Fragments of charcoal, burnt clay, stone tools and pottery (Pl. 9.142-146) were detected in both layers and were especially concentrated between the two layers (Fig. 18).

The construction of Structure 7 was documented only with a few post-holes that were discovered in the central part of the deepening. The deepening of the structure yielded one cultural layer (SE $16=$ $18=25$ ), which was ${ }^{14} \mathrm{C}$ dated, with some smaller pits (SE 37, SE 26 and SE 21) beneath. The cultural layer contained fragments of burnt clay, charcoal, Early Eneolithic stone tools and pottery (Pl. 8.134141), as well as two concentrations of burnt clay (Fig. 19).

The deepening of ${ }^{14} \mathrm{C}$ dated Structure 1 (SE 600) showed two major concentrations of charcoal with fragments of burnt clay (SE 623, SE 625), probably part of the structures' burnt construction, and a cultural layer SE 599. Stone tools and pottery fragments were found in SE 599 (Pl. 9.149-152) and in the concentrations of charcoal (Pl. 9.147-148, 153), where two ${ }^{14} \mathrm{C}$ samples were collected (Fig. 20).

The last ${ }^{14} \mathrm{C}$ dated structure, Structure 10, was identified as a pit (SE 1028) filled with layer SE 1027, which contained a large quantity of burnt clay, charcoal and fragments of pottery (Pl. 10.160-164). A hearth (SE 1029) was discovered next to the pit (both Phase 1). On top of layer SE 1027 and the hearth, another layer, SE 1004, was discovered which contained fragments of charcoal, burnt clay and various fragments of Early Eneolithic pottery (Pl. 10.154-157) (Phase 2). Post-hole SE 1040, also containing fragments of Early Eneolithic pottery (Pl. 10.158-159), was discovered under layer SE 1027. It was therefore assumed that it represented part of Structure 10 (Fig. 21).

Ten out of eleven dates from one part of the settlement at Zgornje Radvanje, which was investigated in 2007 and 2008, more or less overlap and date the settlement to the last third of the $5^{\text {th }}$ millennium BC. Sample Beta-305862 from post-hole SE 1040 was dated somewhat later, to the end of the $5^{\text {th }}$ and beginning of the $4^{\text {th }}$ millennium $\mathrm{BC}$ (Figs. 22-23). The

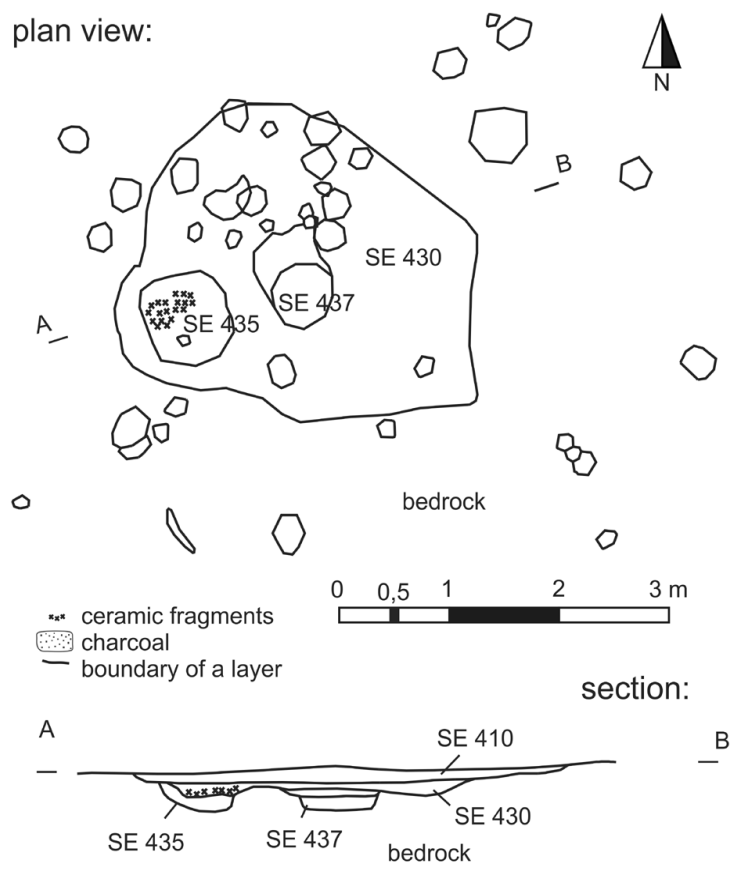

Fig. 11. Ptuj-Šolski center. Structure IV. Plan and section.

post-hole was, as already mentioned, discovered beneath layer SE 1027, so it was assumed that it was related to Structure 10 (Phase 1). However, charcoal sample Beta-305861 from SE 1027 yielded an earlier date, which is consistent with the rest of the settlement. So post-hole SE 1040 was perhaps dug into Structure 10 from the later layer SE 1004 (Phase 2), which is located above the layer SE 1027 and its cut into later layers was not detected (Fig. 21). This seems credible, but no ${ }^{14} \mathrm{C}$ dates are yet available from SE 1004, so we can not completely exclude the possibility that the ${ }^{14} \mathrm{C}$ dating of sample Beta-305862 from pit SE 1040 is incorrect in its context (Bronk Ramsey 2009b.1023-1024).13

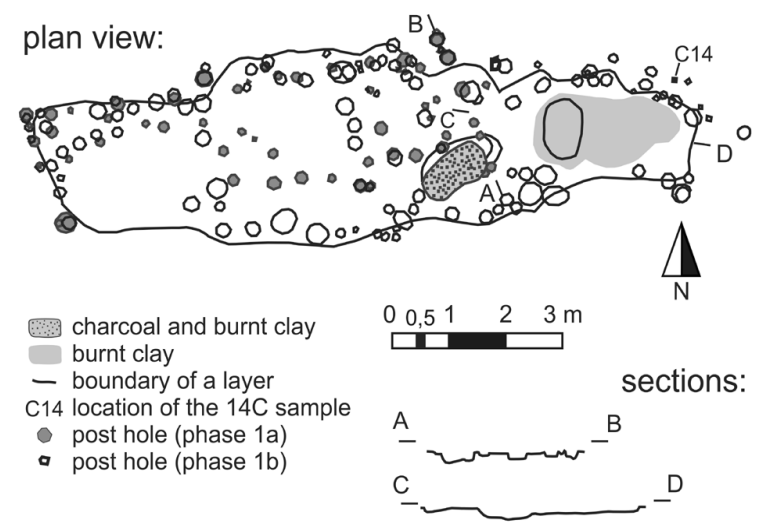

Fig. 12. Ptuj-Šolski center. Structure II. Plan and section. 


\begin{tabular}{|c|c|c|c|c|c|c|c|c|}
\hline Site & Context & $\begin{array}{l}\text { Lab } \\
\text { Code }\end{array}$ & Material & $\begin{array}{l}\text { Age } \\
\text { (BP) }\end{array}$ & $\begin{array}{l}\text { SD } \\
( \pm a)\end{array}$ & $\begin{array}{c}\text { CalBC } \\
(68.2 \%)\end{array}$ & $\begin{array}{c}\text { Cal BC } \\
(95.4 \%)\end{array}$ & Reference \\
\hline Ptuj-Š.c. & Structure II (?) & Z-3015 & charcoal & 5873 & 132 & $4901-4556$ & $5202-4449$ & Obelić et al. 2002.626 \\
\hline Ptuj- & Structure II (SE 10) & Z-3114 & charcoal & 5626 & 80 & $4527-4366$ & 4680 & $\begin{array}{l}\text { Lubšina-Tušek 2004.75 } \\
\text { (only mentioned) }\end{array}$ \\
\hline Ptuj-Š.c. & Structure IV (SE 410) & LTL5611A & charcoal & 5504 & 50 & $4445-4272$ & $4455-4260$ & first published here \\
\hline Ptuj-Š.c. & Structure IV (SE 430) & LTL5612A & charcoal & 5387 & 45 & $4330-4176$ & $4339-4059$ & first published here \\
\hline Ptuj-Š.c. & Structure IV (SE 435) & LTL5613A & charcoal & 5384 & 40 & $4328-4177$ & $4336-4065$ & first published here \\
\hline
\end{tabular}

Figs. 13 and 14. Ptuj-Šolski center. ${ }^{14} \mathrm{C}$ AMS dates. Date, not included in further analyses, is shown with inclined letters.

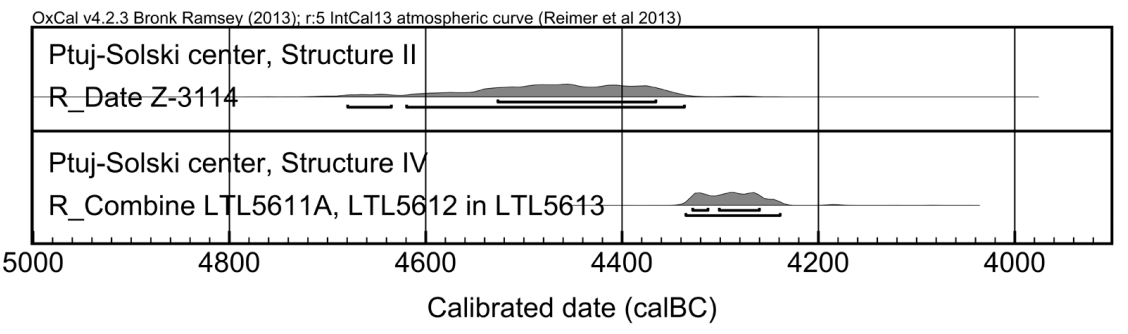

\section{Hoče-Orglarska delavnica}

The latest site studied in this paper and the only one without ${ }^{14} \mathrm{C}$ dates is Hoče-Orglarska delavnica. ${ }^{14}$ In 1988 and 1989 Roman and Bronze Age settlements were discovered and partially studied, together with five hollows from the period studied in this paper (Strmčnik Gulič 1989.224-226; 1990.173-175).

Most of the pottery was found in three pits which were investigated in 1989 and interpreted as pithouses (Strmčnik Gulič 1990.174-175).15 Pit-houses I and II contained a single cultural layer, which yielded burnt clay, charcoal, fragments of stone tools and pottery (Pl. 11 and Pl. 12.180-188), while pit-house III contained two cultural layers with pottery (Pl. 12.189-192) and a higher concentration of burnt clay mixed with charcoal. Layer 9 filled the deepening of the pit (Phase 1); a concentration of burnt clay and charcoal - probably the remains of a hearth - was situated on top of it, while layer 5 (Phase 2) represents the top layer (Fig. 24).

\section{Neolithic-Eneolithic settlement in NE Slovenia}

The settlements at Andrenci, Stoperce, Ptuj-Šolski center and Zgornje Radvanje yielded a total of 20 dated samples, while part of the site at Radvanje-Ha- bakuk 2 (Arh 2012) offers another five dated samples. These provide a relatively good basis for explaining past events (Figs. 9-10, 13-14, 22-23 and their comments). Andrenci, two settlement phases at Stoperce and Ptuj-Šolski center offer only individual ${ }^{14} \mathrm{C}$-dated structures, ${ }^{16}$ while the studied part of Zgornje Radvanje yielded a number of dates, so it is possible to analyse the life span of the settlement. The dates of the samples derived from the same structure were combined before calibration (function R. Combine), so that they were evenly represented during the activity period. 17 In contrast, dates that refer to a variety of contexts were studied separately. The 'Span' function, which determines only the duration of directly dated events, was used, together with the 'Interval' function, which determines the whole range of activities between the beginning and the end of one phase (Fig. 25).18

Based on the presented ${ }^{14} \mathrm{C}$ dates, it is possible to conclude that the studied part of the settlement at Zgornje Radvanje, as well as the settlements at Andrenci, Stoperce and Ptuj-Šolski center document a time span of settlement activities in the period between the second half of the 47 th and the first half of the $40^{\text {th }}$ century BC, while the studied part of the Radvanje-Habakuk 2 settlement, partly dates back to

14 Early Eneolithic pits from Hoče-Orglarska delavnica were not radiocarbon dated because there were no suitable samples. The settlement is dated only indirectly by typological comparisons.

15 Post-holes were detected only at pit-house III, while the remaining pits were interpreted as pit-houses solely on the basis of the fragments of burnt clay and charcoal discovered in them.

16 As mentioned above, two structures were dated at Ptuj-Šolski center, but one reliable ${ }^{14} \mathrm{C}$ date comes from Structure II, with a large standard deviation.

17 The R_Combine function can, by definition, merge only ${ }^{14} \mathrm{C}$ dates relating to the same event, yielding a more precise date for this event, but it is also used to merge samples from the same pit (Stadler, Ruttkay 2007). The difference in the result is minimal in this case, as the merged dates relate to events which were more or less simultaneous.

18 Analyses were done with the OxCal program version v4.2.3 (Bronk Ramsey, Lee 2013) and the current calibration curve (Reimer et al. 2013). 
the first and the second half of the $4^{\text {th }}$ millennium BC (Arh 2012.Fig. 10; 2012. Fig. 40). According to the current chronology of the 'central and southern Slovenian Neolithic and Earlier Eneolithic' and ${ }^{14} \mathrm{C}$ dates that are known so far, the settlements at Andrenci, Stoperce, Ptuj-Šolski center and Zgornje Radvanje can be placed in the period between the Younger or Late Neolithic and Early Eneolithic, while the settlement in the studied part of Radvanje-Habakuk 2 dates partly to the Middle Eneolithic period ( $\mathrm{Ve}$ lušček 2011. 225-233).

The earliest settlement, dating to the end of the first half and the middle of the $5^{\text {th }}$ millennium $\mathrm{BC}$, was documented at Andrenci and Stoperce (Structure I SE 128). Ptuj-Šolski center - Structure II, is younger and dates to the 4527-4366 calBC (68.2\% probability), followed by a whole range of contexts with dates which more or less overlap: Structure IV at Ptuj-Šolski center, and Structures 7, 4, 5, 1, 22, 6 and 10 (Phase 1) at Zgornje Radvanje.19 With the Span function, the life span of the part of settlement at Zgornje Radvanje, determined by structures 7, 4, 5, 1, 22, 6 and 10 (Phase 1) has been estimated to not more than 95 years ( $95.4 \%$ probability), or not more than 43 years ( $68.2 \%$ probability), between 4355 4186 calBC and 4337-4226 calBC respectively; more- over, the 'Interval' function yielded a maximum life span of 146 years in the period between 4355 and 4186 BC (95.4\% probability) or a maximum of 60 years in the period between 4337 and 4226 calBC (68.2\% probability). 20

Structures 7, 4, 5, 1, 22, 6 and 10 (Phase 1) at Zgornje Radvanje are earlier than Structure III (SE 150) at Stoperce, from post-hole SE 1040 at Zgornje Radvanje and individual contexts from part of the settlement at Radvanje-Habakuk 2, researched in 2010 (Arh 2012.Fig. 61). These latest contexts are dated to the end of the $5^{\text {th }}$ and the beginning of the $4^{\text {th }}$ millennium BC.

\section{Pottery assemblages}

The Neo-Eneolithic settlements at Andrenci, Stoperce, Ptuj-Šolski center, Hoče-Orglarska delavnica and the studied part of the settlement at Zgornje Radvanje yielded 38398 pottery fragments (over $409.479 \mathrm{~kg}$ ). The pottery assemblages differ in quantity: the largest was discovered at Zgornje Radvanje (26 408 sherds $(291.7 \mathrm{~kg})$ ), followed by Ptuj-Šolski center (5908 sherds $(65 \mathrm{~kg})$ ), Hoče-Orglarska delavnica (1584 sherds $(33.9 \mathrm{~kg}))$ and the second settlement phase at Stoperce (2522 sherds (14.6kg)). The pottery assemblages from Andrenci and the first settlement phase at Stoperce are the smallest and comparable in quantity (Andrenci, according to S. Pahič 1976.45 - 1050 fragments; Stoperce - 1186 fragments $(4.3 \mathrm{~kg})$ ) (Fig. 26).

\section{Pottery production}

2723 ceramic objects, which were mended from 16848 pottery fragments, were analysed according to the established method of macroscopic standards (Horvat 1999); 62 different fabrics were identified. Quartz (A), mica (C) and iron oxide (E) are present in all fabrics, only the size of grains and their frequency differ. In addition, some fabrics were characterised by whitish, somewhat softer grains, undefined in more detail. LM20, LM23 and LM59 were charac-

Fig. 15. Zgornje Radvanje 2007-2008. General plan of the site.

19 Structure 1 at Radvanje-Habakuk (Arh 2012.Fig. 10) is dated to the same period.

20 Later ${ }^{14} \mathrm{C}$ dates from Zgornje Radvanje are therefore largely a result of the characteristics of the calibration curve in the second half of the $5^{\text {th }}$ millennium BC. This is quite curved and therefore more intersections of the value of the conventional dates with calibration curve occur, while dates have subsequently extended ranges (Wiener 2012.428-429). 


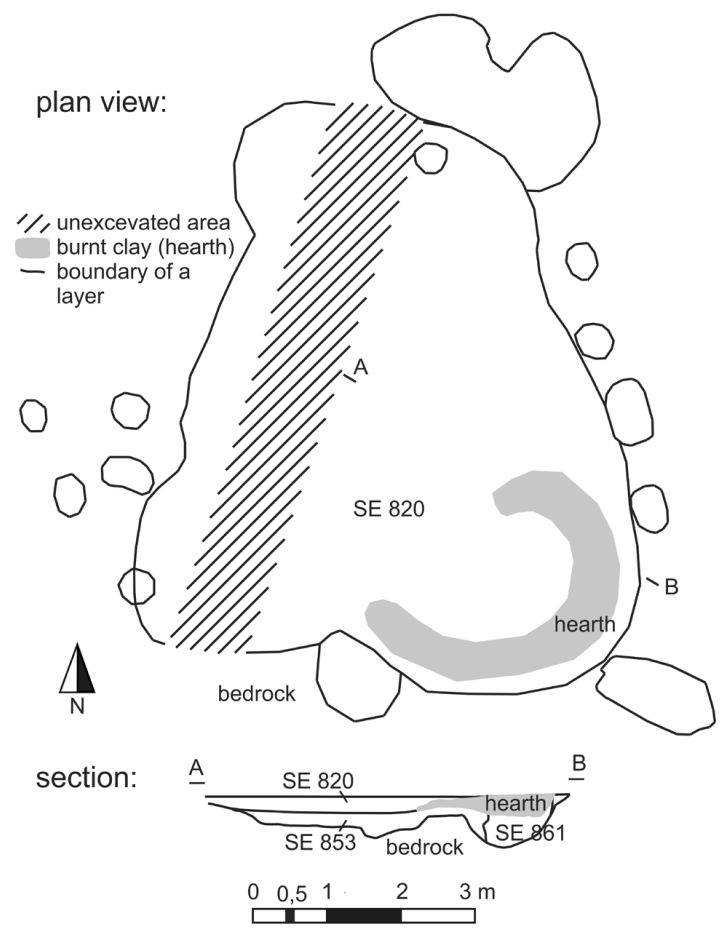

Fig. 16. Zgornje Radvanje. Structure 22. Plan and section.

terised by partially burnt organic material. 21 The fabrics are macroscopically comparable, apart from the Andrenci pottery, which differs slightly in having a smaller amount of mica, which is probably due to different clays being used, as mica is naturally present in clay and its decomposition takes a place around $900-950^{\circ} \mathrm{C}$ (Guirao et al. 2014.757-758; App. 1).

Most of the pottery was made of fabrics without quartz temper, and fabrics with a small amount of quartz temper. Andrenci (83\%), Zgornje Radvanje (61\%), Hoče-Orglarska delavnica (74\%) and pits from the second phase of the settlement at Stoperce (66\%) are dominated by pottery fragments made of very fine-grained fabrics. Fine-grained pottery was less frequent (most of it was found in pits from the second settlement phase at Stoperce - 21\%); coarsegrained fabric was even less common. Only Structure I at Stoperce and Ptuj-Šolski center yielded slightly more pottery made of fine-grained fabrics (58\% and 52\%) (Fig. 27).

The pottery was hand-thrown and finished with treatment of the exterior and interior to remove irregularities from the surface of the objects. At An- drenci, most of the pottery surface is uneven or rough, which means that their surface was smoothened before firing (98\%). Structure I at Stoperce (91\%), Ptuj-Šolski center (74\%), Zgornje Radvanje (92\%), Hoče-Orglarska delavnica (83\%) and pits from the second phase of the settlement at Stoperce (88\%) were dominated by pottery with smooth surfaces which were sponged before firing (Fig. 28).22

In some cases, the surface was coated with a coloured clay slip, most frequently red. This type of pottery was discovered at Andrenci (3\%), Structure I at Stoperce (32\%), Ptuj-Šolski center (9\%), Zgornje Radvanje (3\%) and at Hoče-Oglarska delavnica (7\%); it was coated with either a thicker layer of resistant slip (probably applied before firing, it now crumbles off the pottery surface), or thinner slips that can be removed from the pottery surface if touched with a wet finger (Fig. 29).

The decoration was made with fingers or various tools prior to firing. Three techniques of decoration can be seen - impressions, incisions and applied decoration - wherein the motif was made with a single technique or a combination of two or three techniques. Impressions of the tips of various tools, and

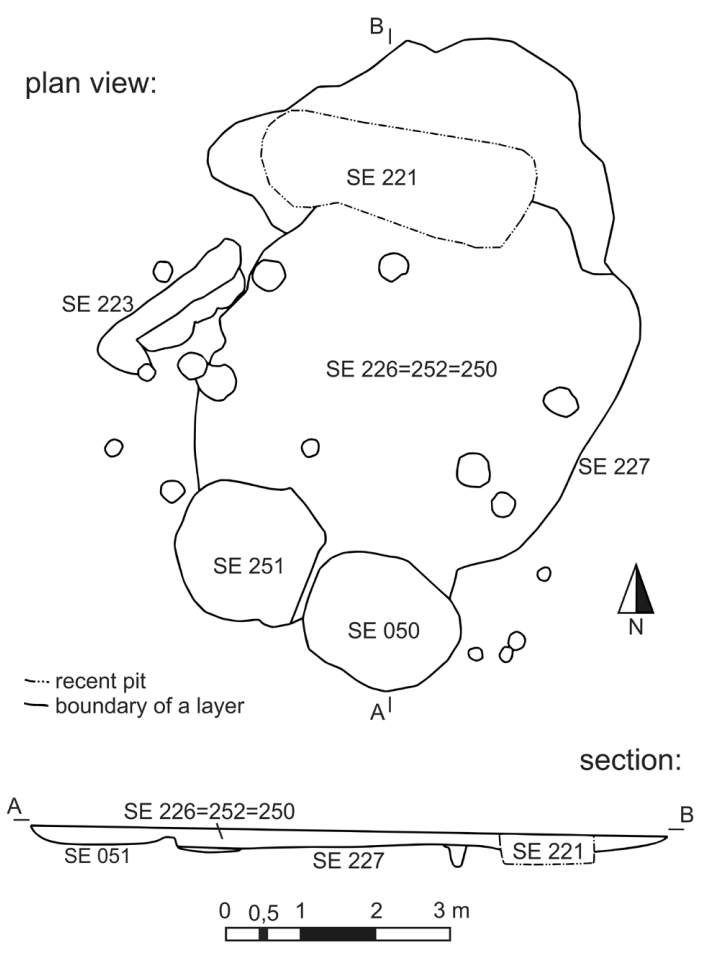

Fig. 17. Zgornje Radvanje. Structure 6. Plan and section.

21 Fabric LM18 is the only fabric containing grains of calcium carbonate. It was documented on the fracture of the base of a vessel from pit SE 52 at Stoperce. Its form resembles late prehistoric vessels, so it is assumed that it was not primary deposited in the pit. 22 Polished pottery is rare. It was found at Zgornje Radvanje (4\%), Hoče-Orglarska delavnica (5\%) and the Early Eneolithic pits at Stoperce (2\%) (Fig. 27). 
fingernail and fingertip impressions can be seen on the pottery surface. Incised decoration is a technique that includes dragging a tool tip/s across the surface, while applied decoration involves making an applique which is later applied to the surface. 23 The largest ratio of decorated pottery to undecorated vessels was discovered in Structure I at Stoperce (47\%), Ptuj-Šolski center (39\%) and in Hoče-Orglarska delavnica (37\%). Less decorated pottery was found at Andrenci (28\%), Zgornje Radvanje (25\%) and in the pits of the second settlement phase at Stoperce (15\%) (Fig. 30). ${ }^{24}$

Individual sites are dominated by different decorating techniques. At Andrenci, most of the pottery was decorated with simple protrusions made with applied decoration (80\%) and rarely with impressions (15\%) or incisions (5\%). Structure I at Stoperce is dominated by applied decoration and impressions (both $30 \%$ ), with incisions (13\%), combinations of incisions and impressions (13\%), a combination of applied decoration and impressions (9\%) and a combination of incisions and applied decoration (5\%). The pottery at Ptuj-Šolski center more often has impressions (46\%), while the quantities of applied decoration (28\%), incisions (14\%) and combinations of incisions and impressions (9\%) are comparable to pit SE 128 at Stoperce. Most of the pottery from Zgornje Radvanje (49\%) and Hoče-Orglarska delavnica (52\%) was decorated with incisions, while a smaller proportion has applied decoration (Radvanje 25\%, Hoče $14 \%$ ), impressions (Radvanje $14 \%$, Hoče $15 \%$ ) or combinations of incisions and impressions (Radvanje $10 \%$, Hoče 15\%). Most of the ware from the second settlement phase at Stoperce is decorated with impressions ( $40 \%$ ) or a combination of incisions and impressions (30\%) (Fig. 31).

The firing atmosphere differs from vessel to vessel, wherein two firing conditions are most common. Vessels from all the sites were most often fired under oxidising conditions, wherein the firing temperature was too low and the oxygen was insufficient for the complete combustion of organic material.

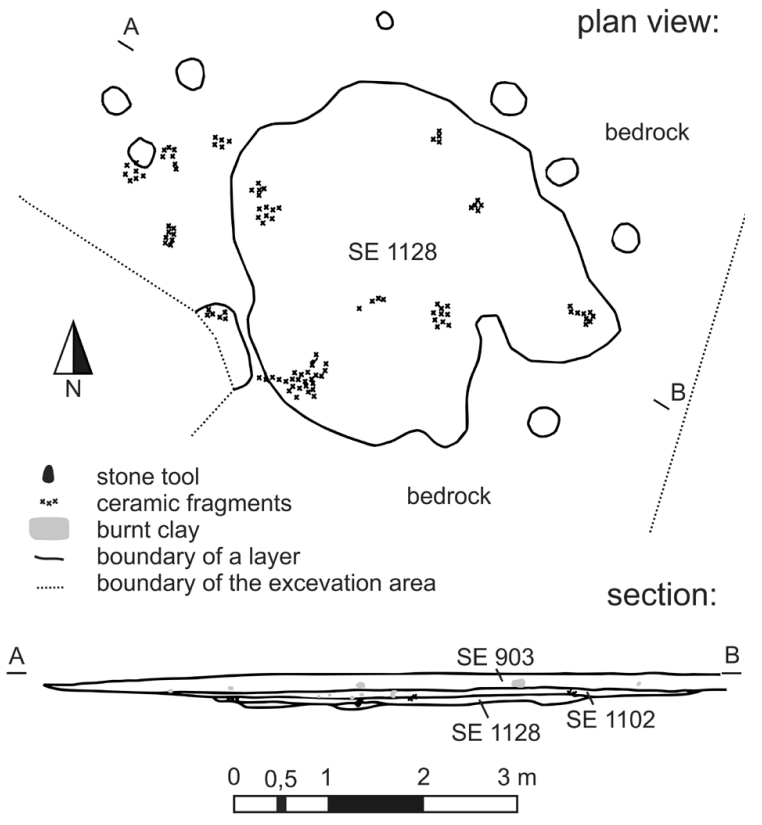

Fig. 18. Zgornje Radvanje. Structure 4. Plan and section.

Typically, the surfaces and fractures of pottery fired under these conditions have several bright hues $(5$ or more), with several grey areas that indicate partially burnt organic material. ${ }^{25}$ Another common firing technique was with incomplete oxidation with a reducing phase at the end of the process. As the name suggests, vessels were constantly fired in oxidising conditions and the oxygen supply intentionally reduced during cooling. The pottery fractures are in bright colours, with darker grey tones on the surface. Such pottery was found in pit SE 128 at Stoperce. It is rare in comparison with pottery fired under incomplete oxidising conditions (13\%), but occurs more often at Ptuj-Šolski center (29\%), Zgornje Radvanje (30\%), Hoče-Orglarska delavnica (24\%) and the Early Eneolithic pits at Stoperce (40\%). Some pottery fragments from Zgornje Radvanje $(0.20 \%)$, Ptuj-Šolski center (1\%) and from pits from the second phase of the settlement at Stoperce (3\%) had fractures and surfaces with a uniform dark grey colour. These vessels were fired under reducing conditions, with constant temperature and reduced oxygen supply while firing as well as cooling (Fig. 32). ${ }^{26}$

23 Appliqués are discussed as parts of decoration, as some are very decorative (Kramberger 2014a.Fig. 149), although they probably also served as an aid in holding the object (like handles and lugs).

24 The results need to be observed with caution. Namely, analyses included all rim fragments of vessels of closed forms, all fragments of vessel girths, all handle fragments, all fragments of the feet of footed vessels. Some of these were, within the studied pottery assemblage, never decorated or decorated rarely.

25 All pottery from Andrenci was fired under these conditions, while SE 128 in Stoperce had 87\%, Šolski center 70\%, Zgornje Radvanje $63 \%$, Orglarska delavnica $76 \%$ and the second phase of the settlement at Stoperce a total of $57 \%$ of pottery fired under these conditions.

26 According to the pottery fractures, complete oxidation, oxidation with reduced atmosphere in the final stage and reduced firing with the oxidising atmosphere in the final stage were determined. Fragments were mostly very small, so it is possible that the evaluation would be different if sherds were larger. 


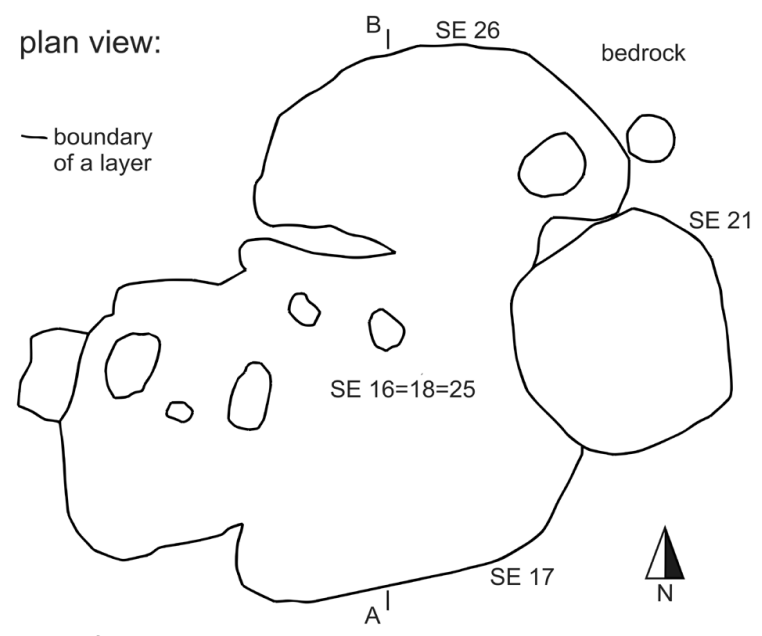

section:

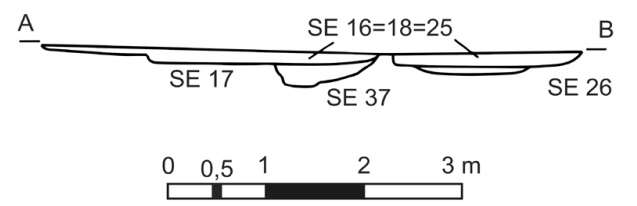

Fig. 19. Zgornje Radvanje. Structure 7. Plan and section.

The hardness of the pottery was determined by macroscopic analysis. A statistical comparison of the results of a Mohs test showed that the pottery from Structure I at Stoperce, Ptuj-Šolski center, Zgornje Radvanje, Hoče-Orglarska delavnica and the Early Eneolithic pits at Stoperce was on average harder (dominated by a value of 3-6 on the Mohs' scale of hardness) than the pottery from Andrenci (values 1-4 on the Mohs' scale of hardness) (Fig. 33). The hardness of pottery depends on many factors, the most important of which are the composition and microstructural properties of clay, the surface treatment of vessels prior to firing, firing temperature and atmosphere (Rice 1987. 354). ${ }^{27}$

\section{Forms of pottery, decoration and typological comparisons}

The pottery found at the settlements from the $5^{\text {th }}$ millennium $\mathrm{BC}$ differs in form and decoration, with some notable differences from site to site which can be seen between contexts, which according to the results of ${ }^{14} \mathrm{C}$ analyses, date to different periods, as well as between contexts that were contemporaneous. Good comparisons are available in different geographic areas and the studied sites can be connected to different cultural groups.

As mentioned above, according to the current chronology of the 'central and southern Slovenian Neolithic and Earlier Eneolithic and ${ }^{14} \mathrm{C}$ dates known so far, the settlements at Andrenci, Stoperce, PtujŠolski center and the studied part of the settlement at Zgornje Radvanje date to the Younger or Late Neolithic and Early Eneolithic (Velušček 2011.225-233). According to the above chronology, the earliest settlement in central and south-eastern Slovenia is culturally defined as pertaining to the Sava group of the Lengyel Culture, followed by the Lasinja Culture, dated to the Early Eneolithic period, and later by the horizon of pottery with furrowed incisions, which is dated to the Middle Eneolithic (Velušček 2011.209).

The chronological scheme of the 'central and south Slovenian Neolithic and Earlier Eneolithic' is comparable to the Austrian chronological scheme, with the only difference being the terminology used. ${ }^{28}$ However, a very different chronological scheme exists in neighbouring Croatia (Marković 1994.27-29) and Hungary. The transition from the Neolithic to the Copper Age is better defined in Hungary, where the Sé horizon, early and middle phases of the Lengyel Culture (West Hungary) and the Tisza Culture (East Hungary) define the Late Neolithic period. Phase Lengyel III (West Hungary), which according to Anton Veluščk is correlated with the Sava group of the Lengyel Culture (Velušček 2011.210-222), and the Proto-Tiszapolgár and Tiszapolgár horizons (East Hungary) date to the Early Eneolithic period, while the Balaton-Lasinja Culture and the horizon of pottery with furrowed incisions ('Furhenstich') date to the Middle Eneolithic period (Raczky 1974; Makkay 1976; Zalai-Gaál 1982; Kalicz 1973; also Bánffy 1995c.192; 1997.61). The transition from the Neolithic to Eneolithic has been explained by changes in society and lifestyle, supposedly related to the spread of new technologies from the area of the central Balkans to Central Europe (Bánffy 1995c.183-187). Contacts with the central Balkans are also supposed to be seen in a number of new forms of pottery that first appear during the Late Lengyel Culture and which are a specific feature of the subsequent Balaton-Lasinja Culture (Bánffy 2002).

27 The results of the analysis need to be treated with caution, since the analysis was carried out with a magnifying glass, not a microscope. Moreover, the Mohs hardness test is not entirely relevant for gritty pottery (Rice 1987.357).

28 In Austria, the Lengyel Culture and related cultural groups (e.g., Moravia - East-Austrian group of painted ceramics, Stichbandkeramik, the Münschöfen Culture) define the Middle Neolithic, while the Kanzianiberg-Lasinja and related cultures define the earlier phase of the late Neolithic period, which equates to the Copper Age in Austria (Krenn-Leeb 2006.Fig. 2). 


\section{The second half of the $47^{\text {th }}$ to the beginning of the $45^{\text {th }}$ century BC}

Differences in pottery forms and pottery decoration can be seen at Andrenci (Pls. 1-2) and Structure I at Stoperce (Pl. 3), although they were absolutely dated to approximately the same era, i.e. between the $47^{\text {th }}$ and mid $45^{\text {th }}$ century BC (95.4\% probability) or between the second half of the 47 th and the beginning of the $45^{\text {th }}$ century BC (68.2\% probability). Differences can be noticed mainly in the forms of pots and decorative motifs, while, for example, footed dishes, dishes and jugs are almost identical.

To begin with, we focus on finds with no significant differences, because such finds have been found over a wide geographical area. The pottery assemblages from Structure I at Stoperce (Pl. 3.52, 54, 56) as well as from both structures at Andrenci (Pl. 1.1.2, 16, 23; Pl. 2. 26, 38) often include dishes with a convex body and an everted rim (cf. Kramberger 2014. 285-287), which stood either on a base or low cylindrical foot (cf. Kramberger 2014.288-289). ${ }^{29}$ Furthermore, all contexts contain dishes with a convex body and a straight rim (Pl. 1.3, 18; Pl. 2.37, 40; Pl. 5.3, 58; see also Kramberger 2014.290)30 and jugs with a low-convex body, shoulders and a long or medium sloping neck (Pl. 1.10; Pl. 2.44; Pl. 3.59; see also App. 2.V11-V13).31 The so-called beak-spouted rims (Pl. 1.21-22),32 the 'buta' type of vessel with horizontal handles of a triangular form (Pl. 24.1; Pl. 2.49; see also Kramberger 2014.159-161, 299), ladles with a punctured handle attachment and a semispherical receptacle (Pl. 2.47-48) and a ladle with a punctured handle attachment and a semi-ellipsoidal receptacle (Pl. 19.1; cf. Kramberger 2014.298) only appear at Andrenci; these are generally known types of pottery from the $5^{\text {th }}$ millennium $\mathrm{BC}$ in Central and South-eastern Europe.

Differences in pot forms are more significant. Apart from differences, defined as versions, it was discovered that structures A and B at Andrenci yielded only pots with rounded body (Pl. 1.11-12, 20) and an everted neck (Pl. 1.6, 11-12; Pl. 2.28, 31, 33-

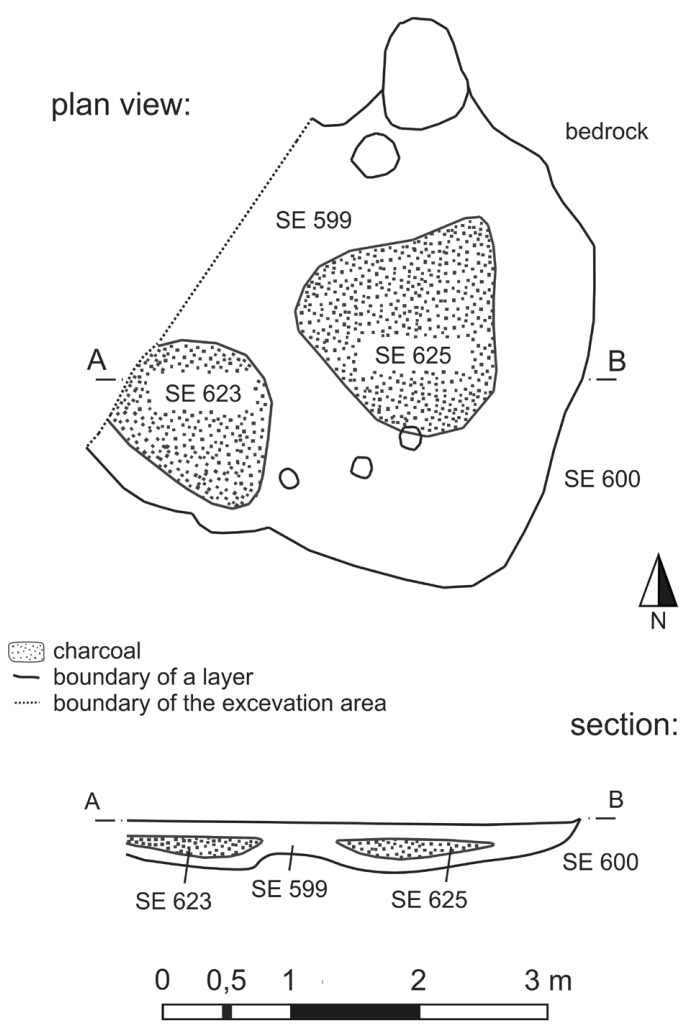

Fig. 20. Zgornje Radvanje. Structure 1. Plan and section.

34), 33 while better preserved pots from Structure I at Stoperce have concave bodies (Pl. 3.66-69) and strongly everted (Pl. 3.63, 69), slightly everted (Pl. 3.60) as well as ellipsoidal necks (P1. 3.62, 64) (see also App. 3. L24.1-L15.1-2). The upper parts of pots have vertical strap handles, a characteristic of pots from the end of the first half of the $5^{\text {th }}$ millennium BC onwards in Austria (MOG IIa and IIb; Stadler, Ruttkay 2007.142-143) and Hungary (end of the Phase II and Phase III of the Lengyel Culture; Bánffy 1995b.87; Zalai-Gaál 2003.294-295).

A common feature of pottery decoration at Andrenci and SE 128 from Stoperce are plastic motifs on girths (Pl. 1.1-2, 7, 9, 10, 12, 17, 20; Pl. 2.29-30, 32, 37, 42-44, 46; Pl. 3.58-60, 63, 65, 68), while there is a great difference in the frequency of occurrence of such motifs in comparison with other types of decoration. Applied motifs are the most common tech-

29 Simple dishes with feet tapering at the end appear individually at Andrenci (Pl. 13.1).

30 SE 128 at Stoperce yielded a similarly formed dish with a concave body (Pl. 3.57).

31 Good comparisons are available at, for example, the Late Lengyel sites of Nagykanizsa-Inkey-Kápolna, Zalaszentbalázs-Szólóhegyi mező and Čatež-Sredno polje (cf. Horváth, Kalicz 2006.58; Velušček 2011c.214-242; Kramberger 2014.Fig. 186).

32 Comparisons can be found at, for example, the sites of Lengyel Culture, the Sopot Culture and at Čatež-Sredno polje (Kramberger 2014.291).

33 Although only three such pots are typologically identified, based on fragments of the lower parts of the vessels, it is possible to assume that the majority were of this form. All fragments of closed vessels from structures A and B have rounded bodies, while the necks of all closed vessels from structures A and B were everted. We can assume that most of these fragments are fragments of pots, while some could be from jugs or the 'buta' type of vessels. 
nique of decoration at Andrenci, 34 while the decoration of pottery from Structure I at Stoperce is diverse. Apart from applied decoration, one can notice impressions (Pl. 3.64, 66-67), a combination of impressions and applied decoration (Pl. 3.63, 68), a combination of impressions and incisions (Pl. 3.62, 69), incisions and a combination of incisions and applied decoration (Pl. 3.65). A feature of the ware from Andrenci has to be stressed, i.e. decoration with a large bulge on the rim of a vessel (Pl. 2.45) and horizontally perforated appliqué (Pl. 1.5), while only pottery from SE 128 at Stoperce has two small plastic bulges (Pl. 3.58) and horizontal elongated appliqués (Pl. 3.52, 54).

Pottery which disparates Andrenci from Structure I at Stoperce can be found in different geographic areas. The Andrenci pottery mainly resembles pottery assemblages dating to the end of Phase II and from Phase III of the Lengyel Culture in West Hungary, in Styria (for a review, see Obereder 1989; Tiefengraber 2006) and Bukovnica (Šavel 1992.59-60), and is thus the extreme southwest site where such pottery occurs. The West Hungarian sites are the most researched among the sites mentioned. Firstly, the site at Zalaszentbalázs-Szólőhegyi mezô has to be mentioned (for an analysis of decoration, see Bánffy $1995 b$. 78-80), followed by, for example, sites at Nagykanizsa-InkeyKápolna (Kalicz 2003; Horváth, Kalicz 2006), Tekenye (Katalin 1987), Veszprém (Regenye 2007), Szentgál-Füzi-Kút (Regenye 1994) and Kaposvár-Gyertyános (Regenye 2006). These sites yielded pots with rounded bodies, everted necks and vertical strap handles (cf. Pl. 12.1 with Bánffy 1995b.Pl. 71.179, with Regenye 2007.Fig. 2.1), which are almost identical to the pots described above. Moreover, the pottery is decorated with similarly formed appliqués ( $c f . \mathrm{Pl}$. 1.5: Bánffy 1995b.Pl. 53.16; Pl. 63.109; Pl. 71.199; Pl. 92.126-127, Kalicz 2003.Pl. 4.12-14, Pl. 5.4, Regenye 1994.Fig. 8.19, Fig. 11.7, Regenye 2006, with Šavel 1992.Pl. 5.16; cf. Pl. 2.45: Bánffy $1995 b$.
Pl. 71.179, Katalin 1987.Fig. 26.12). Similar forms and decoration also appear at sites dated to the late phase of the Moravia - East Austrian group of painted pottery (MOG) in Austria (Stadler, Ruttkay 2007. 140, 142-143; cf. Pl. 1.11 with Ruttkay 1976.Pl. 3.3), while similar forms, but decorated with painted ornament, occur at sites dated to the middle phase of the MOG (e.g., Stadler, Ruttkay 2007.138139, 142; cf. Pl. 1.12 with Neugebauer, NeugebauerMaresch 2006.Fig. 3.8; Pl. 2.45 with Carneiro 2006. Fig. 5. 1-2). Good comparisons can, moreover, be found in late phases of the Brodzany-Nitra Group in Slovakia (cf. Pl. 2.45 with Rakovsky 1986.Fig. 1.1, Fig. 2.1, 4, with Kuča et al. 2011.Fig. 5.10 and Košturik 1979.Pl. 1.8, Pl. 4.4, Pl. 7.5, 7).

The form and decoration of pottery from Structure I (SE 128) at Stoperce, on the other hand, mainly resembles sites in central and south-eastern Slovenia. Good comparisons can be found at settlement phase 2 at Moverna vas (Budja 1995.Fig. 4; Tomaž 1999), at Resnikov prekop (Harej 1975; Korošec 1964) and at Gradišče pri Stiški vasi (Velušček 2005). Individual comparisons also occur at, for example, ČatežSredno polje (Tomaž 2010; Tomaž, Kavur 2006) and Dragomelj (Turk, Svetličič 2005), where it seems

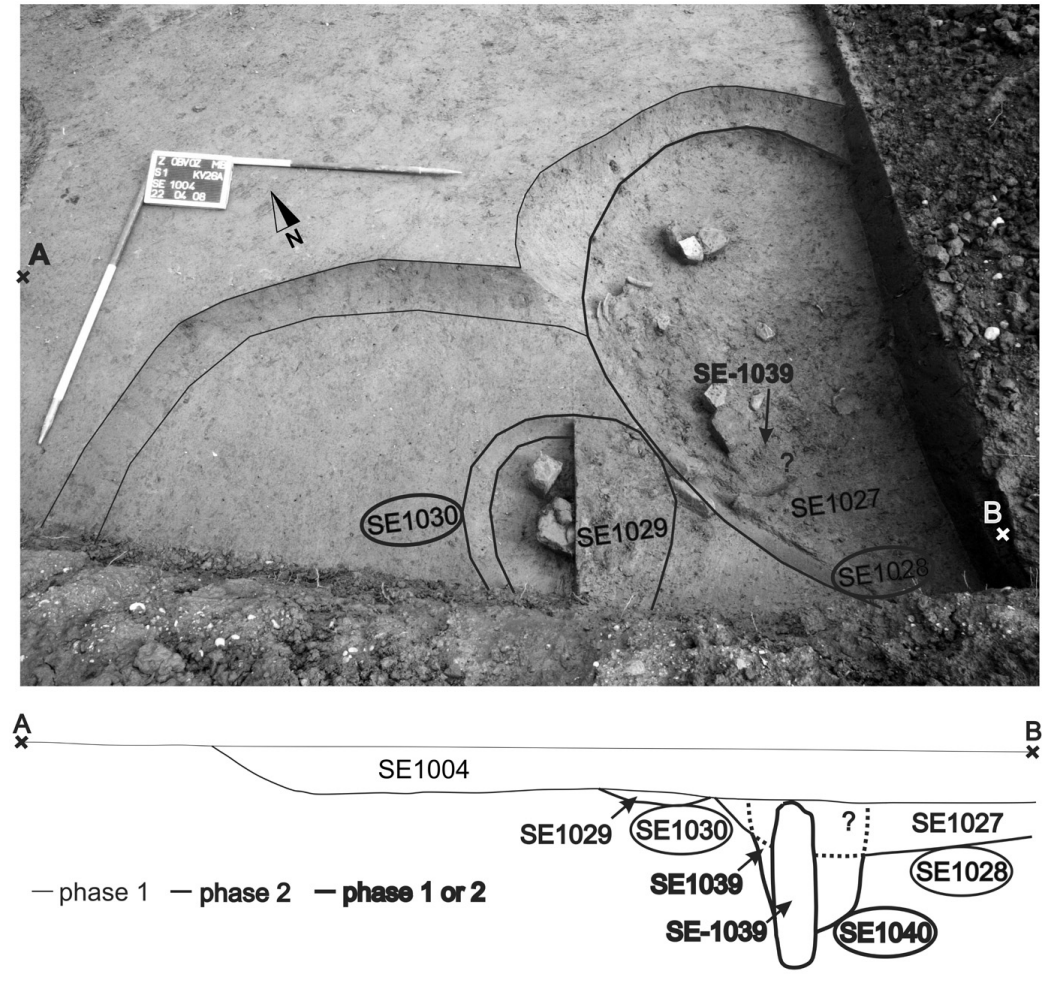

Fig. 21. Zgornje Radvanje. Structure 10. Photo and segment of partially researched structure.

34 Structure A yielded 19 vessels decorated with plastic motifs, while Structure B yielded 9 vessels with this type of decoration. According to the statistics, as already stated, this means that $80 \%$ of pottery was decorated with plastic motifs, $15 \%$ of motifs were impressed (Pl. 28.2, 34, 50) and only 5\% were incised (Pl. 1.8). 


\begin{tabular}{|c|c|c|c|c|c|c|c|c|}
\hline Site & Context & $\begin{array}{l}\text { Lab } \\
\text { Code }\end{array}$ & Material & $\begin{array}{l}\text { Age } \\
\text { (BP) }\end{array}$ & $\begin{array}{l}\text { SD } \\
( \pm a)\end{array}$ & $\begin{array}{c}\text { CalBC } \\
(68.2 \%)\end{array}$ & $\begin{array}{c}\text { Cal BC } \\
(95.4 \%)\end{array}$ & Reference \\
\hline Zg. Radvanje & Structure 7 (SE 2O) & Beta-305853 & charcoal & 5450 & 40 & $4346-4262$ & $4361-4236$ & first published here \\
\hline Zg. Radvanje & Structure 4 (SE 11O2) & Beta-305863 & charcoal & 5430 & 40 & $4336-4260$ & $4354-4177$ & first published here \\
\hline Zg. Radvanje & Structure 5 (SE 324) & Beta-305855 & charcoal & 5370 & 40 & $4325-4079$ & $4331-4057$ & first published here \\
\hline Zg. Radvanje & Structure 5 (SE 330) & Beta-305856 & charcoal & 5420 & 40 & $4332-4259$ & $4352-4082$ & first published here \\
\hline Zg. Radvanje & Structure 1 (SE 623) & Beta-305857 & charcoal & 5430 & 40 & $4336-4260$ & $4354-4177$ & first published here \\
\hline Zg. Radvanje & Structure 1 (SE 625) & Beta-305858 & charcoal & 5320 & 40 & $4233-4061$ & $4316-4042$ & first published here \\
\hline Zg. Radvanje & Structure 22 (SE 853) & Beta-305860 & charcoal & 5350 & 40 & $4312-4071$ & $4323-4052$ & first published here \\
\hline Zg. Radvanje & Structure 22 (SE 820) & Beta-305859 & charcoal & 5410 & 40 & $4329-4246$ & $4348-4076$ & first published here \\
\hline Zg. Radvanje & Structure 6 (SE 250) & Beta-305854 & charcoal & 5360 & 40 & $4321-4074$ & $4328-4054$ & first published here \\
\hline Zg. Radvanje & Structure 10 (SE 1027) & Beta-305861 & charcoal & 5370 & 40 & $4325-4079$ & $4331-4057$ & first published here \\
\hline Zg. Radvanje & Structure 10 (SE 1040) & Beta-305862 & charcoal & 5190 & 40 & $4040-3964$ & $4223-3824$ & first published here \\
\hline
\end{tabular}

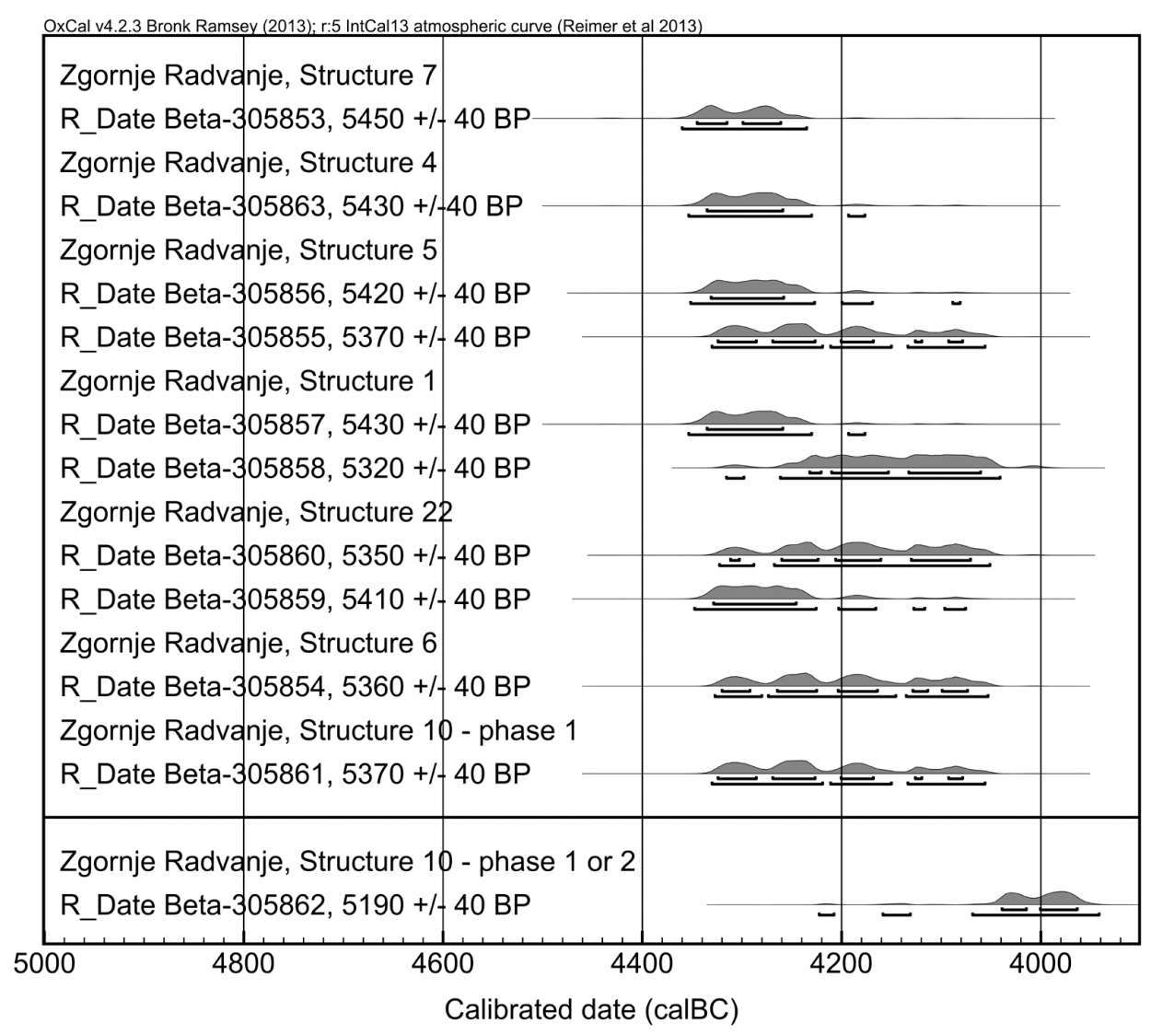

Figs. 22 and 23. Zgornje Radvanje. ${ }^{14} \mathrm{C}$ AMS dates from part of the settlement, which was investigated during 2007 and 2008.

that more pottery is decorated with impressions. 35 These sites yielded identical or similar decorated pots, with concave bodies, strongly everted ( $c f$. Pl. 3.63 with Tomaž 1999. Pl. 14.1, with Harej 1975.Pl. 1.6; cf. Pl. 3.69 with Tomaž 1999.Pl. 12.1-2),36 slightly everted (cf. Pl. 3.60 with Tomaž 2010.find no. 668) and ellipsoidal necks (cf. Pl. 3.62 with $V e$ lušček 2005. find no. 8; see also the pot from settlement phase 2 in Budja 1995.Fig. 4). Dragomelj, Resnikov prekop, Čatež-Sredno polje and Gradišče pri
Stiški vasi, all of these with artefacts that are comparable to the studied pottery, have been dated to the so-called Sava Group of the Lengyel Culture. According to Mitja Guštin, Moverna vas in Bela Krajina is not attributed to this group (Guštin 2005.Fig. 1). However, Velušček considers that the distribution of this cultural group is wider and includes sites in Bela Krajina, around Karlovac, Kočevsko and Slovenian Styria (Velušček 2011.206), which is confirmed by the pottery from the deepening of Structure I at Stoperce.

35 According to the analysis, which was presented by Alenka Tomaž, this is reliable, especially for ČatežSredno polje (Tomaž 2010), while a study of the whole Dragomelj site has to be published first in order to confirm or disprove this.

36 The second settlement phase of Moverna vas offers the best comparisons with footed dishes decorated with a horizontally elongated appliqué (cf. Pl. 3.52, 54 with Tomaž 1999.Pl. 5.2). 


\section{End of the 46th to $43^{\text {rd }}$ century BC}

Based on individual ${ }^{14} \mathrm{C}$ date from Structure II and dates from Structure III, the site at Ptuj-Šolski center can be dated to between the end of the $46^{\text {th }}$ and $43^{\text {rd }}$ century BC (Fig. 25). The date partly overlaps with dates from both, i.e. Structure I at Andrenci and Zgornje Radvanje. This indicates that Ptuj-Šolski center may have been contemporary with Structure I at Stoperce and with Andrenci, as well as with the structures at Zgornje Radvanje. However, the pottery assemblages found in the structures differ from site to site.

Based on pottery assemblages, Ptuj-Šolski center is culturally dated to the Late Lengyel Culture (Kavur 2010.71 ) or the 'wider Lengyel Culture' (Guštin 2005.9, Fig. 1; Tomaž 2010.164). The comparisons presented in this paper are only partly consistent with this definition. In addition to finds that are comparable to material from Andrenci and Structure I at Stoperce, Structures I-IV also yielded finds comparable to the Lasinja Culture in the region. The most important feature of the Late Lengyel Culture (Carneiro 2004.267-271) and the 'wider area of the Lengyel Culture' (Guštin 2005.12-13) are vessels with a coloured clay slip. 37 It can be seen on dishes of identical or similar forms as those from Andrenci and SE 128 at Stoperce: on dishes with a convex body and an everted rim (Pl. 5.82; Pl. 6.100), simple hemispherical dishes (Pl. 5.78 ; Pl. 6.92), dishes with a convex body, of simple form with a tapered upper part, where the base is not preserved (Pl. 5.90; Pl. 6.94, 102), on high hollow cylindrical feet (Pl. 6.96) and on numerous foot fragments. 38

In addition to the presented dishes with clay slip, which were probably footed, PtujŠolski center yielded many footed dishes with a convex body and straight rim decorated with four tongued appliqués (Pl. 5.79, 81, 89; $\mathrm{Pl}$. $6.93,95)$ which have been identified as a typical find of the Slovenian Lasinja Culture (Guštin et al. 2005.47; Veluščk 2011.222). These were usually fired under incom- plete oxidising conditions, with reducing conditions used at the end of the firing process. The same firing process was used for high hollowed sloping feet (Pl. 6.99), high hollowed sloping feet, convex in the middle (Pl. 5.83), high hollowed sloping feet, convex on top, and differently formed low feet (Pl. 6.97-98). Some footless dishes and bowls were similar in form (Pl. 6.101, 103) occur together with dishes with a simple semi-circular form (Pl. 5.91). Handles or spouts, semi-circular spouts with a partition (Pl. 5.91), or thrown spouts (Pl. 5.84) could be attached to all types of dishes and bowls as well as footed dishes.

Even more differences can be seen between jugs and pots from Ptuj-Šolski center and those from Andrenci and Structure I at Stoperce. In contrast with the jugs from SE 128 at Stoperce and Andrenci, the typologically determined jugs from Ptuj-Šolski center have a low concave body (Pl. 6.104-106), shoulders and either short and slightly sloping (Pl. 6.106) or long cylindrical necks (see also App. 2). Pots usually have a high concave body, shoulders and a medium (Pl. 5.86; Pl. 6.107) or short cylindrical neck or a long sloping neck (Pl. 6.108). Pots of different forms are rare (Pl. 6.88; see also App. 3).

The ceramic finds are most often decorated with impressed, applied, incised and impressed-incised motifs; some are comparable to those from Structure I at Stoperce (cf. Pl. 3.52, 54 with Pl. 6.92; $c f$. Pl. 3. 63, 68 with Pl. 6.106). Different motifs also occur (Pl. 6.103); they are more comparable to those at Zgor-

37 Ptuj-Šolski center, as already stated, yielded more slip-coated pottery than Andrenci, but less than SE 128 at Stoperce (Fig. 28). 38 No base fragments covered with slip were found at the site, so we can assume that most of the presented variations were footed. 
nje Radvanje and Hoče-Orglarska delavnica ( $c f$. with Pl. 8.128 and Pl. 12.182, 186, 188).

Typological comparisons reveal great similarities in the pottery from the nearby site of Rabenstein near Lawamünd, which, according to the chronology of $\mathrm{E}$. Ruttkay, dates to the Early Lasinja Culture (Tiefengraber 2004; Carneiro 2004; see also Krenn-Leeb 2006.195, Fig. 2). The pottery from this site is relatively fragmented; however, several forms can be identified: dishes with a convex body and everted rim ( $c f$. Pl. 5.82 with Tiefengraber 2004.Pl. 5.45) and dishes with a simple semi-circular form with a conical top (cf. Pl. 6.102 with Tiefengraber 2004.Pl. 2.15-16, Pl. 4.33, Pl. 14.152-153) coated with red slip and probably footed; simple spherical dishes with spouts, with partition of semi-circular form ( $c f$. Pl. 5.91 with Tiefengraber 2004.Pl. 5.49, Pl. 9.95); jugs with a low concave body (cf. Pl. 6.105 with Tiefengraber 2004.Pl. 2.20-21, Pl. 8.79, Pl. 11.114115 ) and almost identical decoration (cf. Pl. 5.87 with Tiefengraber 2004.Pl. 10.101; Pl. 6.103 with Tiefengraber 2004.Pl. 3.29; Pl. 6.101 with Tiefengraber 2004.Pl. 14.150). Comparisons of some forms of pottery which from Ptuj-Šolski center which differs from that found at Andrenci and Structure I at Stoperce are known from some sites in central and south-eastern Slovenia, the most important being: the ${ }^{14} \mathrm{C}$ dated settlement phases Moverna vas 4, 5 and partly 6 ( $c f$. dish with a thrown spout - Pl. 5.84

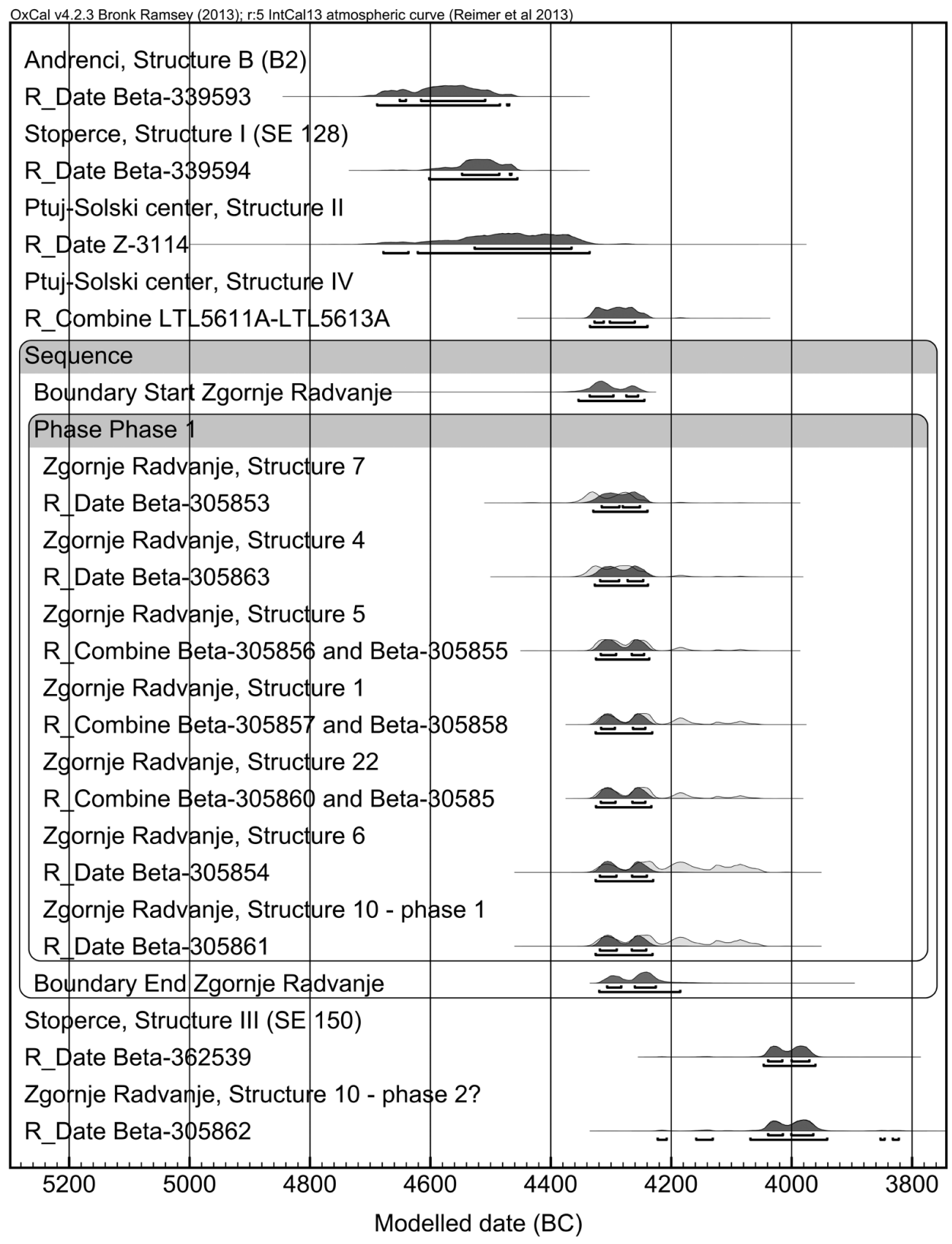

Fig. 25. Settlement chronology at Andrenci, Stoperce, Ptuj-Šolski center and part of Zgornje Radvanje. 


\begin{tabular}{|lccc|}
\hline Settlement & $\begin{array}{c}\text { Amount of fragments } \\
\text { before mending }\end{array}$ & $\begin{array}{c}\text { Amount of fragments } \\
\text { after mending }\end{array}$ & $\begin{array}{c}\text { Total weight of pottery } \\
\text { fragments (kg) }\end{array}$ \\
\hline Andrenci & 1050 & $/$ & $/$ \\
\hline Stoperce - settlement phase 1 & 1186 & 850 & $4,28 \mathrm{~kg}$ \\
\hline Stoperce - settlement phase 2 & 2522 & 1714 & $14,58 \mathrm{~kg}$ \\
\hline Ptuj-Šolski center & 5908 & 4465 & $64,995 \mathrm{~kg}$ \\
\hline Zgornje Radvanje & 26408 & 18086 & $291,677 \mathrm{~kg}$ \\
\hline Hoče-Orglarska delavnica & 1584 & 895 & $33,947 \mathrm{~kg}$ \\
\hline All settlements together & 38398 & $26010+$ Andrenci & $409,479 \mathrm{~kg}+$ Andrenci \\
\hline
\end{tabular}

Fig. 26. Size of studied pottery assemblages. The only data available from Andrenci is the quantity of pottery fragments that were found in the settlement.

with Tomaž 1999.Pl. 17.4; a pot with a concave body and cylindrical neck - Pl. 5.86 with Tomaž 1999.Pl. 24.1, Pl. 25.1, Pl. 32.6; a jug with a concave body decorated with incisions - Pl. 6.105 with Tomaž 1999.Pl. 31.2-3) and a ${ }^{14} \mathrm{C}-$ dated site at Ponikve pri Trebnjem which is dated to the same era as Structure II at Ptuj-Šolski center (Ravnik, Tica in press) 39 and settlement phases Moverna vas 4 and 5.

In addition to the similarity between pottery from Ptuj-Šolski center and pottery from the sites mentioned above, noticeable differences also exist. The former has frequent imprinted decoration more frequently, while the pot with a low convex body and a sharp transition between a medium cylindrical neck and shoulders, as well as footed dishes with a straight rim and hanging appliqués, which were identified in the region as typical of the Lasinja Culture, are not known at the above-mentioned sites. Is this merely a result of archaeological research, or do we have to look for an answer elsewhere?

Ptuj-Šolski center is located near the so-called 'western route' defined by Eszter Bánffy and based on many elements of southern origin seen on pottery. Sites further away from this route have fewer of these elements (Bánffy 1994.294; 2002.42). As already noted, these links are important, as they help to determine the transition from the Hungarian Late Neolithic to the Copper Age, as they link with changes that should have resulted from spread of new technologies (primarily copper) from the area of the central Balkans to Central Europe. Further research is needed to answer the above question, but, at this point, it is necessary to stress that there are noticeable similarities to pottery from several Copper Age cultural groups in the central Balkans, primarily with the early phases of the Salcuta Culture. Several correlations can be found (Kramberger 2014.292, 308-
309, 310-311). However, the comparison with a uniquely formed pot with a low convex body and sharp transition between medium cylindrical neck and shoulders (Pl. 5.88; Fig. 34.1) has to be stressed here. No similar form has been found at other Slovenian sites ( $c f$. Fig. 34.2).

\section{The end of the $44^{\text {th }}$ and $43^{\text {rd }}$ century BC}

As mentioned above, ${ }^{14} \mathrm{C}$ dates and settlement model date structures 7, 4, 5, 1, 22, 6 and 10 (Phase 1) at Zgornje Radvanje to the late $44^{\text {th }}$ and $43^{\text {rd }}$ century BC ( $68.2 \%$ probability) or, more specifically, between the second half of the $44^{\text {th }}$ and the early $42^{\text {nd }}$ century BC (95.4\% probability) (Fig. 25). Pottery from these structures is typologically well comparable with pottery from Hoče-Orglarska delavnica (cf. Pl. 7-10 with Pl. 11-12), but slightly different from that found at Ptuj-Šolski center, mainly in elements where similarities with Ptuj-Šolski center, Structure I at Stoperce and Andrenci were found.

Namely, Zgornje Radvanje and Hoče-Orglarska delavnica yielded only footed dishes with a straight rim decorated with hanging tongue-like appliqués (Pl. 7.109, 112; Pl. 8.124; Pl. 9.142, 147, Pl. 10.159; Pl. 11.165). Different forms of feet are present (Pl. 8.137; Pl. 11.172; Pl. 12.180, 184; see also Kramberger 2010.Pl. 1.1; Pl. 6.33), the most common being high hollow feet, convex on top (Pl. 7.110; Pl. 8.123; Pl. 10.155; Pl. 12.183). Dishes and bowls were formed similarly to footed dishes. 40 They have applied handles (Pl. 8.126; Pl. 11.166; Pl. 12.186), lugs (Pl. 12.192), appliqués (Pl. 7.113; Pl. 11.168) or spouts. Semi-circular spouts with a partition (Pl. 9.145) and thrown spouts (Pl. 9.143; Pl. 10.154) appear with a protrusion/protrusions on the inside, and circular spouts with partition (Pl. 7.111; Pl. 11.170) and extracted spouts (Pl. 7.115; Pl. 12.181) are also present.

39 I am grateful to Mateja Ravnik that enabled me to get an insight to the dating and pottery and allowed me to mention the yet unpublished data at this stage.

40 Only bowls with a concave body, shoulders and rim differ (Pl. 11.168, see also Kramberger 2010b.Pl. 1.6-7). 


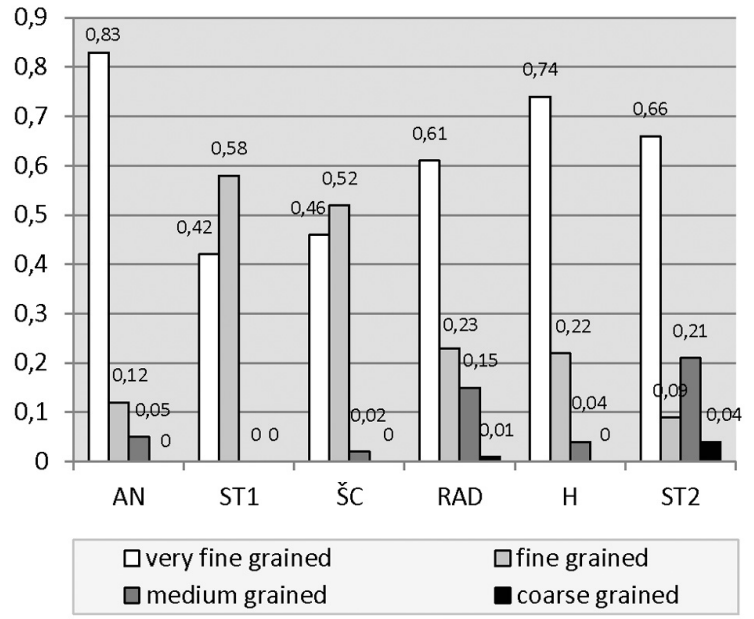

Fig. 27. Andrenci (AN), Stoperce - settlement phase 1 (ST1), Ptuj-Šolski center (ŠC), Zgornje Radvanje (RAD), Hoče-Orglarska delavnica and Stoperce settlement phase 2 (ST2). Percentage of different granularity groups of fabrics.

Jugs with a low concave body, low shoulders and a long, cylindrical (Pl. 7.116; Pl. 11.174; Pl. 12.182) or slightly sloping neck (Pl. 10.162) are similar in form to jugs found at Ptuj-Šolski center, but the shoulders are often extremely thickened (see also Pl. 8.128, Kramberger 2010.Pl. 7.41, 45). Jugs with identically formed upper parts, but a high concave body (P1. 7.121; Pl. 8.136; Pl. 11.171; Pl. 12.185, probably also Pl. 9.144), and jugs with a high concave body and long strongly sloping necks (Pl. 8.127, 135; Pl. 9.149) (see also App. 2) are also present.

The most common pot forms are, similarly to PtujŠolski center, pots with a high concave body, shoulders and a sharp transition to a short cylindrical neck (Pl. 8.131; Pl. 11.177-178; 12.187-188; see also Kramberger 2010.Pl. 2.12; Pl. 3.13-15, 18; Pl. 7.48-49; Pl. 9.52; Pl. 10.58), and pots with a high concave body, low shoulders and a long, sloping neck (Pl. 9.152; Pl. 11.176, 179; see also Kramberger 2010.Pl. 7.46-47). Pots with a high concave body, with no shoulders and a long, strongly sloping neck (Pl. 7.122; Pl. 9.146, 153; see also Kramberger 2010. $\mathrm{Pl} .8 .50)$ are also frequent, together with individual finds of pots with a low concave body (Kramberger 2010.Pl. 2.11; Pl. 20.4), a pot with a high concave body, shoulders and medium strongly sloping neck (Pl. 10.164), a pot with a concave body and an indi-

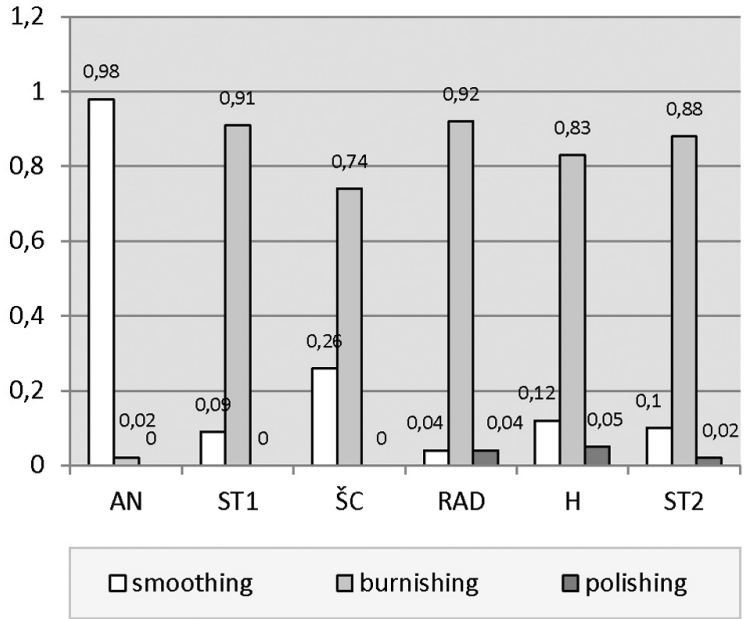

Fig. 28. Andrenci (AN), Stoperce - settlement phase 1 (ST1), Ptuj-Šolski center (ŠC), Zgornje Radvanje (RAD), Hoče-Orglarska delavnica and Stoperce settlement phase 2 (ST2). Percentage of finishing (surface treatment) techniques.

stinct transition to a short slightly sloping neck (Pl. 7.114) and pots with a convex body and a long, slightly sloping neck (Pl. 12.189-190; see also App. $3)$.

Apart from pots, ${ }^{14} \mathrm{C}$-dated structures at Zgornje Radvanje also yielded bottle-like vessels (Pl. 7.118, $\mathrm{Kram}^{-}$ berger 2010b.Pl. 3.17, 9.55). They are similar to the so-called Lasinja bottles - a characteristic of this period, which are also present at Zgornje Radvanje (PI. 7.119) and Hoče-Orglarska delavnica (Pl. 12.191) but incomparably larger (Kramberger 2014.343$344,346-348$ ). They were categorised as pots in the first publication (Kramberger 2010.313, 314), but compared to pots they are more closed and have appliqués instead of handles.

The pottery ladles were made in one piece, with a full (Pl. 8.132) or punctured attachment (Pl. 9.151; Pl. 10.160; Pl. 11. 175) for a handle. The latter is more common, often with one (Pl. 7.117; Pl. 8.141; see also Kramberger 2010b.Pl. 9.53) and sometimes more protrusions, which is characteristic of a period after the Lengyel Culture (Ruttkay 1994. 223).

Pottery similar to that found at Hoče-Orglarska delavnica and Zgornje Radvanje can primarily be found 41 at sites dated later as pertaining to the Lengyel Cul-

41 Some forms and ornaments have comparisons on sites that are dated to the $45^{\text {th }}$ and $44^{\text {th }}$ century BC (Phase 4 and 5 of Moverna vas - see Kramberger 2010b.317-322) and even sites that are dated to the middle of the $5^{\text {th }}$ millennium BC (cf. P1. 9.150 with Pl. 3.66). The datings of some sites which are based on comparisons of a few small pottery fragments do not seem completely convincing (see Tomanič-Jevremov et al. 2006.find no. 2-15 and compare find no. 3 with Pl. 8.133). However, we also have to mention that there are indeed some fragments at Ptujski grad which are characteristic of the pottery of the middle of $5^{\text {th }}$ and first half of $5^{\text {th }}$ millennium BC (Tomanič-Jevremov et al. 2006. find no. 2; Korošec 1951.Fig. 55; 1965.Pl. 11.4) 


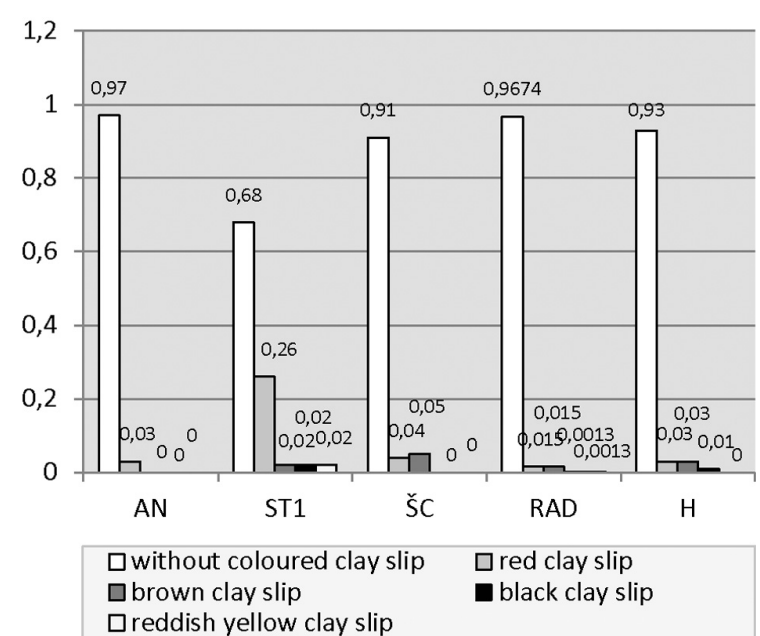

Fig. 29. Andrenci (AN), Stoperce - settlement phase 1 (ST1), Ptuj-Šolski center (̌̌C), Zgornje Radvanje (RAD), Hoče-Orglarska delavnica and Stoperce settlement phase 2 (ST2). Percentage of different coloured clay slips.

ture. Most comparisons are from Lasinja sites in the region, in south-eastern Slovenia and in the Gorenjska region in Northern Slovenia; Zbelovo ( $c f$. Pl. 19. 189-190 with Pahič V. 1983.Pl. 5.1; cf. Pl. 7.119 and Pl. 12.119 with Pahič V. 1983. Pl. 15.10-11) and Brezje pri Zrečah ( $c f$. Pl. 7.119 with Pahič 1956. Pl. 1.2), located at Dravinjske gorice. The Drava plain offers good comparisons at, for example, Hardek ( $c f$. Pl. 12.189-19 with Žižek 2006a.find no. 31; Pl. 7.115 with Žižek 2006a.find no. 20; Pl. 7.114 with Žižek 2006a.find no. 23), part of the pottery from Ptujski grad (Tomanič Jevremov et al. 2006b.178182) and some of the finds from Ormož-Škoršičev

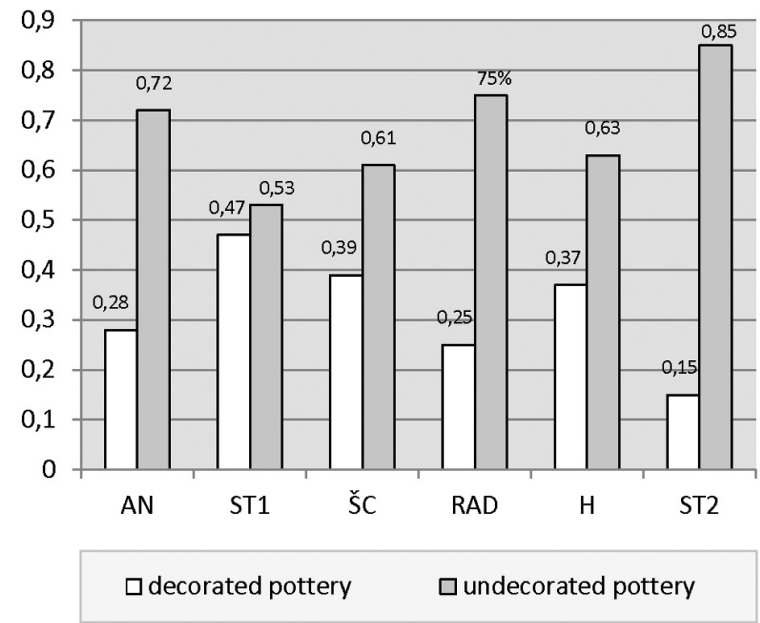

Fig. 30. Andrenci (AN), Stoperce - settlement phase 1 (ST1), Ptuj-Šolski center (ŠC), Zgornje Radvanje (RAD), Hoče-Orglarska delavnica and Stoperce settlement phase 2 (ST2). Percentage of decorated/ undecorated pottery.

vrt (cf. Pl. 12.189 with Tomanič Jevremov et al. 2006a.find no. 21). South-eastern and northern Slovenia offer well comparable pottery finds primarily from burials in Ajdovska jama ( $c f$. Pl. 7.121 with Horvat Mi. 1989.Pl. 6.435; Pl. 11.179 with Korošec Pa. 1975.Pl. 8.1; Pl. 11.176 with Horvat Ma. 1986. Pl. 3.2; cf. Kramberger 2010b.Pl. 3.17 with Horvat Mi. 2009.Fig. 5.10; cf. Pl. 7.119 with Horvat Mi., Horvat Ma. 1987. Fig. 3), finds from the 6th and $7^{\text {th }}$ settlement phase of Moverna vas (Budja 1995. Fig. 4 ), pit PO 004 at Čatež-Sredno polje ( $c f$. Pl. 7.121 with Tiefengraber 2006b. find no. 5), and partly finds from Spaha (Velušček 2011.222-223) and Dru-

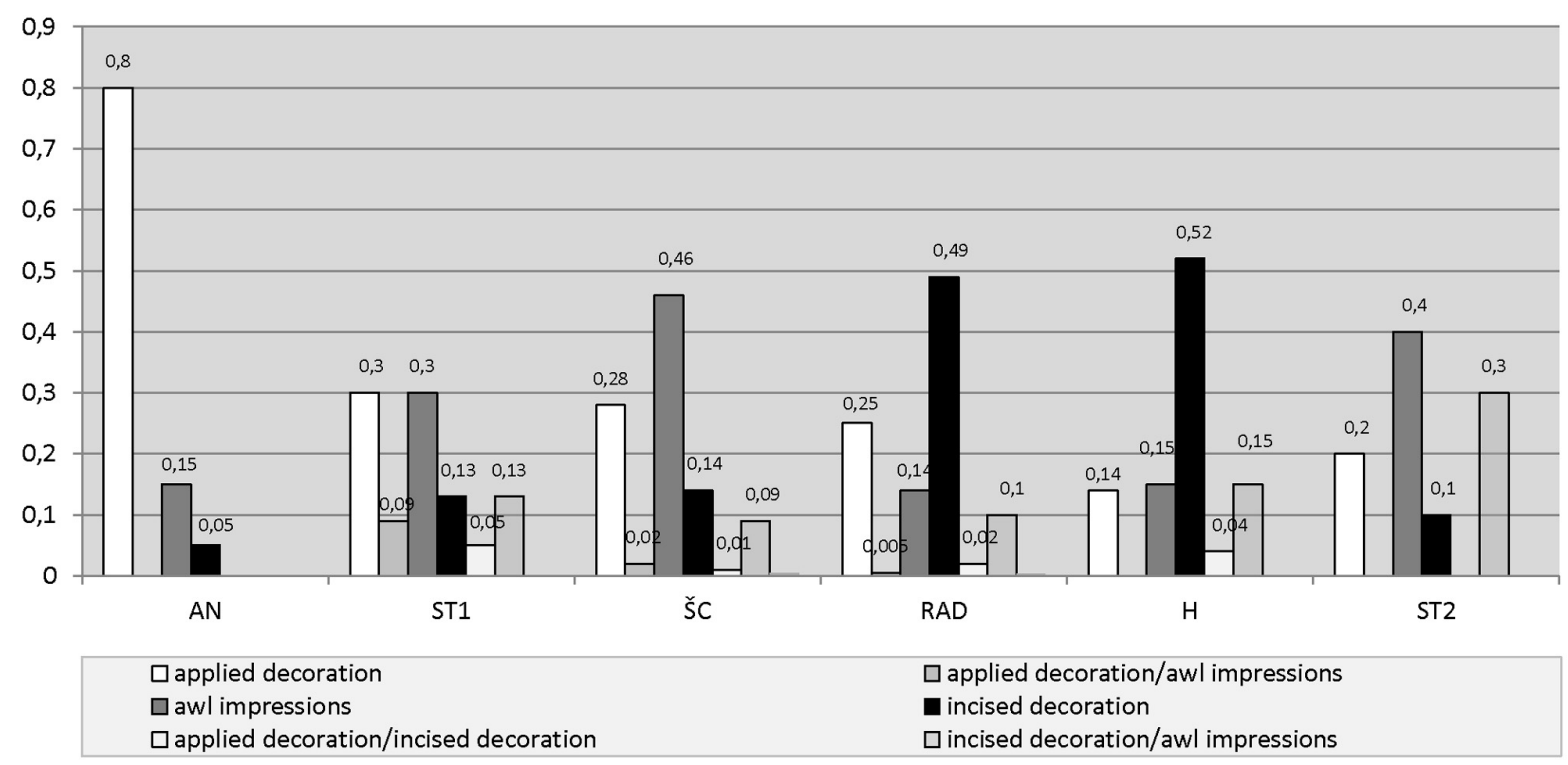

Fig. 31. Andrenci (AN), Stoperce - settlement phase 1 (ST1), Ptuj-Šolski center (ك̌C), Zgornje Radvanje (RAD), Hoče-Orglarska delavnica and Stoperce - settlement phase 2 (ST2). Percentage of pottery decoration techniques. 


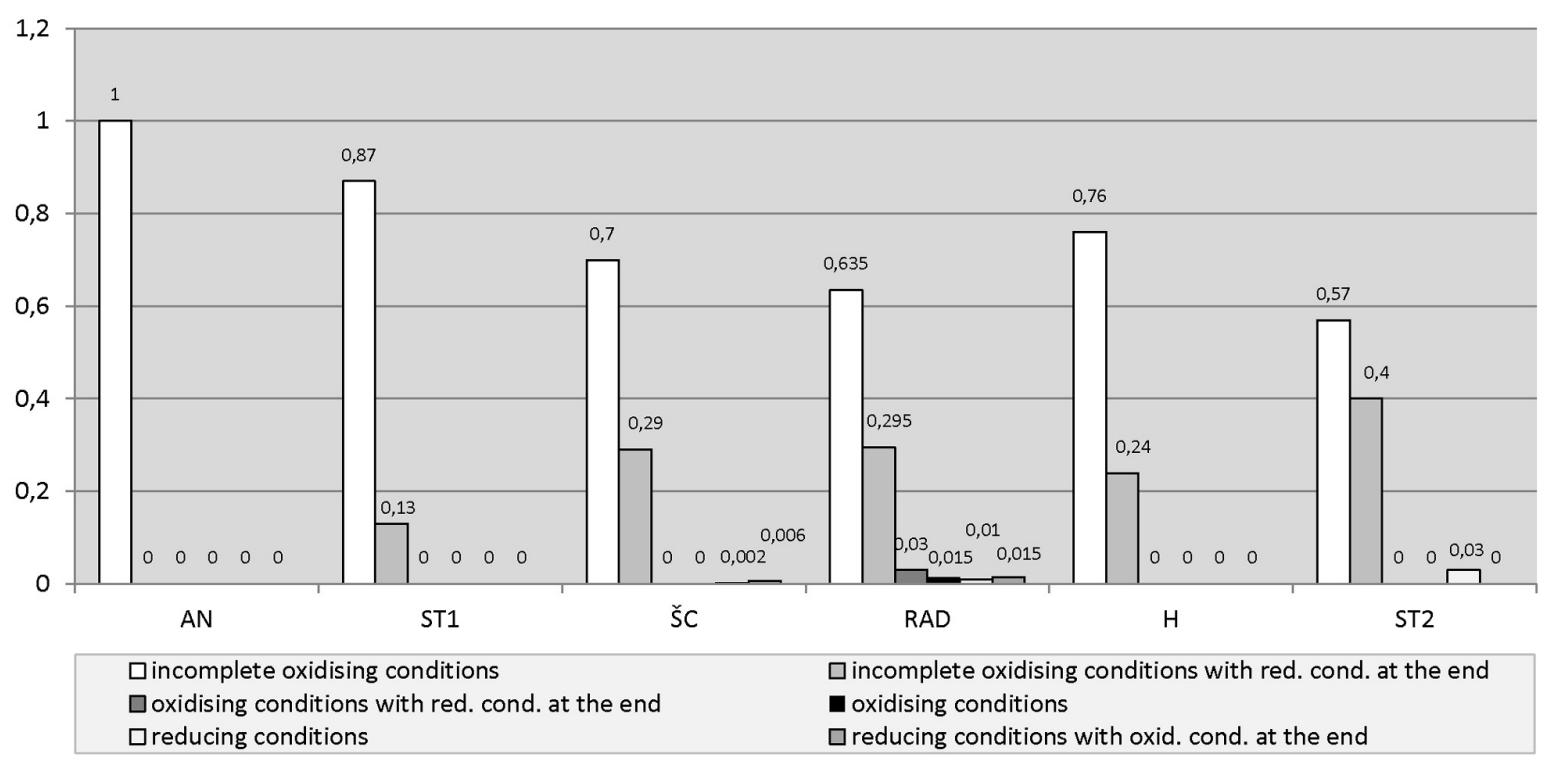

Fig. 32. Andrenci (AN), Stoperce - settlement phase 1 (ST1), Ptuj-Šsolski center (ک̌C), Zgornje Radvanje (RAD), Hoče-Orglarska delavnica and Stoperce - settlement phase 2 (ST2). Percentage of types of firing of pottery (firing conditions).

lovka near Kranj (Guštin et al. 2005.47-50; cf. also Pl. 7.119 with Guštin et al. 2005. find no. 32). 42

The best Austrian comparisons are from Raababerg near Graz (cf. Pl. 7.115 with Obereder 1989.Pl. 15. 155-156; cf. Pl. 9.143 with Obereder 1989.Pl. 18. 183-184, Pl. 20.201-204; cf. Pl. 9.145 with Obereder 1989.Pl. 18.188, Pl. 20.205; cf. Pl. 12.192 with Obereder 1989.Pl. 9.97 and 149), and also from Stillfried (cf. Pl. 7.113 with Hahnel 1991.Pl. 1.2) and Kanzel bei Graz ( $c f$. Pl. 12.189-190 with Artner et al. 2012.Pl. 1.R30-R42, R69).

The other side of Slovenske gorice yielded comparable sites at Sodolek ( $c f$. Pl. 7.114 with Kavur et al. 2006.find no. 5; Pl. 9.143 with Kavur et al. 2006. find no. 2) and Šafarsko (cf. Pl. 7.116 with Šavel 2006.find no. 27; cf. Pl. 12.189-190 with Šavel 1984.Pl. 4.1), which are located on the right bank of the Mura River. Slightly fewer comparisons can be found at sites from the Prekmurje region in eastern Slovenia and Hungary. In Prekmurje, for example, pottery comparisons can be found at Popava 1 near Lipovci (cf. Pl. 12.189-190 with Šavel, Karo 2012. find no. 481; Pl. 7.119 and Pl. 12.119 with Šavel, Karo 2012. find no. 819; Pl. 12.192 with Šavel, Karo 2012. finds nos. 49, 239-240, 507, 717, 729), Turnišče (cf. Pl. 12.189-190 with Tomaž 2012.finds nos. 7-8, 10, 14, 15, 22, 139; Pl. 12.192 with Tomaž 2012.find nos. 435, 485, 487-488), Bukovnica (cf.
Pl. 11.176 with Šavel 1994.Pl. 21.2; $c f$. Pl. 12.189 with Šavel 1994.Pl. 21.13), Kalinovnjek near Turnišč (cf. Pl. 12.189-190 with Kerman 2013a.find no. 408; Pl. 12.192 with Kerman 2013a.find no. $267)$ and Gorice near Turnišče ( $c f$. Pl. 9.152 with Plestenjak 2010.find no. 15). It is also necessary to mention some of the Hungarian sites, particularly Szombathely metro ( $c f$. Pl. 7.121 with Gábor 2004. Pl. 80), Dobri-Alsó-mesö (cf. Pl. 12.189-190 with Horváth, Katalin 2004.Fig. 25.3; Pl. 12.192 with

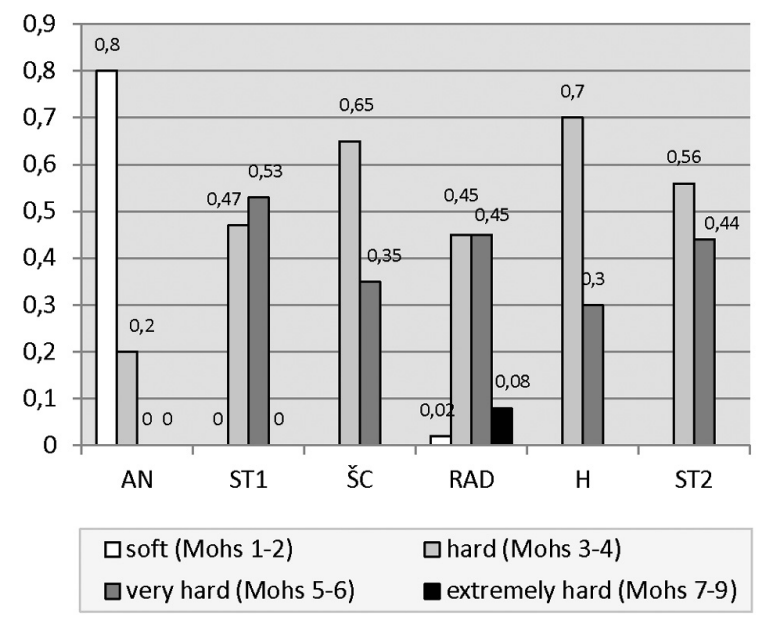

Fig. 33. Andrenci (AN), Stoperce - settlement phase 1 (ST1), Ptuj-Šolski center (ŠC), Zgornje Radvanje (RAD), Hoče-Orglarska delavnica and Stoperce settlement phase 2 (ST2). Percentage of hardness groups of pottery.

42 The miniature bottle from Drulovka has been explained as a representative find of the Sava Group of the Lengyel Culture, but it is not clear on what basis. Resnikov prekop, Čatež-Sredno polje, Dragomelj and other comparable Slovenian sites have not yielded miniature bottles; they are present only at sites of the Lasinja Culture. 
Horváth, Katalin 2004.Fig. 6.5), Sormás (cf. Pl. 12. 189-190 with Straub 2006.Fig. 4.6; Pl. 12.192 with Straub 2006.Figs. 5.3, 8.2, 8.1, 3), Nagykanizsa (cf. Pl. 12.189-190 with Kalicz 1975. Pl. 9.4), Zalaszentbalázs-Pustatetố ( $c f$. Pl. 12.189-190 with Bánffy 1995a.Pl. 32.129), Gellénháza-Városrét (cf. Pl. 12. 191 with Horváth, Katalin 2003. Figs. 22.7, 23.8; Pl. 9.143 with Horváth, Katalin 2003.Fig. 24.7; Pl. 12.192 with Horváth, Katalin 2003.Fig. 24.2), Úyperint-Kavicsbánya (cf. Pl. 7.116 with Károlyi 1992. Pl. 34.4), Mosonszentmiklós-Pálmajor (cf. Pl. 7.113 with Virág, Figler 2007.Fig. 8.1), Kaposvár (cf. Pl. 7.113 with Samogyi 2000.Fig. 13.3), Zalavár-Basasziget (cf. Pl. 12.189-190 with Virág 2003b.Fig. 3.5, Fig. 6.4; Pl. 12.192 with Virág 2003a.Fig. 4.1), Letenye-Szentkerszdomb ( $c f$. Pl. 12.189-190 with Kalicz 1973. Fig. 19.6), Tornyiszentmiklós ( $c f$. Pl. 12.189-190 with Barna 2003.Fig. 6.10) and Nagykanizsa-Sanc ( $c f$. Pl. 12.189-190 with Kalicz 1991. Fig. 8.1).

In Croatia, the best correlations come from Bukovje (cf. Pl. 7.119 with Homen 1985.Fig. 1), Beketinec (cf. Kramberger 2010.Pl. 3.17 with Homen 1990. Fig. 5.8; Pl. 7.118 with Homen 1990.Fig. 2.1; Pl. 7.119 with Homen 1985.Figs. 2-3), Cerje Tužno-Krč (cf. Pl. 7.119 with Marković 1994.Pl. 24.9) and Jakšić (cf. Pl. 12.189-190 with Marković 1985.Fig. 3).

\section{The second half of the 41st and the first half of the $40^{\text {th }}$ century $\mathrm{BC}$}

Pottery from the Early Eneolithic pits at Stoperce, which, based on an absolute date from the hearth in Structure III, can be dated to the period between the second half of the $41^{\text {st }}$ and the first half of the $40^{\text {th }}$ century BC, are typologically homogeneous. The finds that connect Early Neolithc pits at Stoperce, structures 7, 4, 5, 1, 22, 6, 10 (Phase 1) from Zgornje Radvanje, Hoče-Orglarska delavnica and Ptuj-Š́olski center are dishes with a straight rim (Pl. 4.70) on high hollow feet that are convex on top (Pl. 4.71), and decorated with tongue-like appliqués, together with dishes and bowls similar to them. On the other hand, differences can be seen in jug and pot forms and decorative motifs.

The pots and jugs most frequently have an S-shaped profile. These jugs (Pl. 4.74, 77) and pots (Pl. 4.72) differ from one another only in dimensions and the number of handles. Another form of pot has a high concave body, an indistinct transition to the upper part and a long, slightly sloping neck (Pl. 4.75). A jug from the same site is similar in form, but
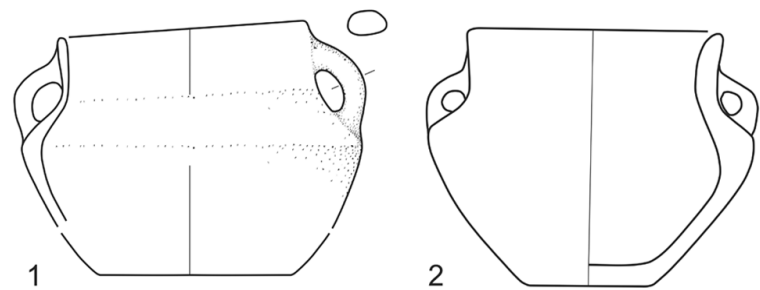

Fig. 34. Comparison to a pot with a low convex body. 1 Ptuj-Śolski center, Structure IV; 2 Salcuta (after Radu 2002.357 - CANA 2B).

has a distinct transition to the upper part (Pl. 4.76) (see also App. 2-3). As mentioned above, the decoration is noticeably different. The most common form consist of individual bunches of incisions that end with awl impressions (Pl. 4.73, 77). Another decoration that has to be mentioned consists of two lines of impressions on the shoulders of a closed vessel (Pl. 4.76) and the upper parts of the feet of footed dishes (Pl. 4.71). A foot of this type was also found in layer SE 1004 in Zgornje Radvanje (cf. Pl. 10.155), which may be linked to post-hole SE 1040 and its absolute date (see Fig. 25 and comments on dates from Zgornje Radvanje).

Again, comparable finds in terms of form and decoration can be found mainly at Lasinja Culture sites and related cultures in neighbouring countries. The best correlations are from Keutschacher See in Austria (cf. Pl. 4.71 and Pl. 10.155 with Samonig 2003. Pl. 40.435; Pl. 4.75 with Samonig 2003.Pl. 13.133; Pl. 4.74, 77 with Samonig 2003. Pl. 13.138 and Fig. 25: Type B2), Pri Muri near Lendava (cf. Pl. 4.72 with Šavel, Sankovič 2011. find nos. 92, 131-132) and Brezje near Turnišče ( $c f$. Pl. 4.71 and Pl. 10.155 with Nov̌sak et al. 2013.find no. 97), and finally in some of the finds from Hardek ( $c f$. Pl. 4.75 with Tušek 1999.Pl. 2.8; Pl. 4.74, 77 with Žižek, 2006.find no. 22).

\section{Chronologically concurrent sites and cultural groups}

To summarise, the best comparisons with the pottery from Andrenci can be found in pottery from the later Lengyel Culture (phases Lengyel IIb and III) in western Hungary, Austrian Styria and Bukovnica and from later phases of the MOG Culture in Austria (phases IIa and IIb), while pottery from chronologically contemporary Structure I at Stoperce correlates with sites in central and south-eastern Slovenia. Pottery from slightly later structures at Ptuj-Šolski center is comparable to pottery from Rabenstein near Lawamünd and some sites in central and south-eastern 
Slovenia, while pottery from Zgornje Radvanje, Hoče-Orglarska delavnica and settlement Phase 2 at Stoperce correlates with Lasinja Culture sites.

${ }^{14} \mathrm{C}$ dates from Structure B in Andrenci and Structure I at Stoperce are comparable with dates from the Late Lengyel site at Zalaszentbalázs-Szőlőhegyi mezó in western Hungary, from Dragomelj, settlement Phase 3 of Moverna vas and some of the dates from Resnikov Prekop (see also Mlekuž et al. 2013. $P l .1)$ and Čatež-Sredno polje. This indicates that these sites were partly contemporary. The unpaint- ed phase of the Lengyel Culture (Lengyel Phase III) was, by definition, concurrent with the 'Phase of unpainted pottery' MOG IIb in Austria, while Phase MOG IIa, which is characterised by multiple colour painting, was probably earlier (Bánffy 1997.61). However, scholars note that this does not correlate with the AMS ${ }^{14} \mathrm{C}$ dating (Velušček 2011.236). This was furthermore confirmed with dates from Andrenci and Structure I at Stoperce, which are earlier than dates from MOG IIb and comparable to MOG IIa (Michelstetten, Oberbergern, Antonshöhe in Reichersdorf) (Fig. 35).

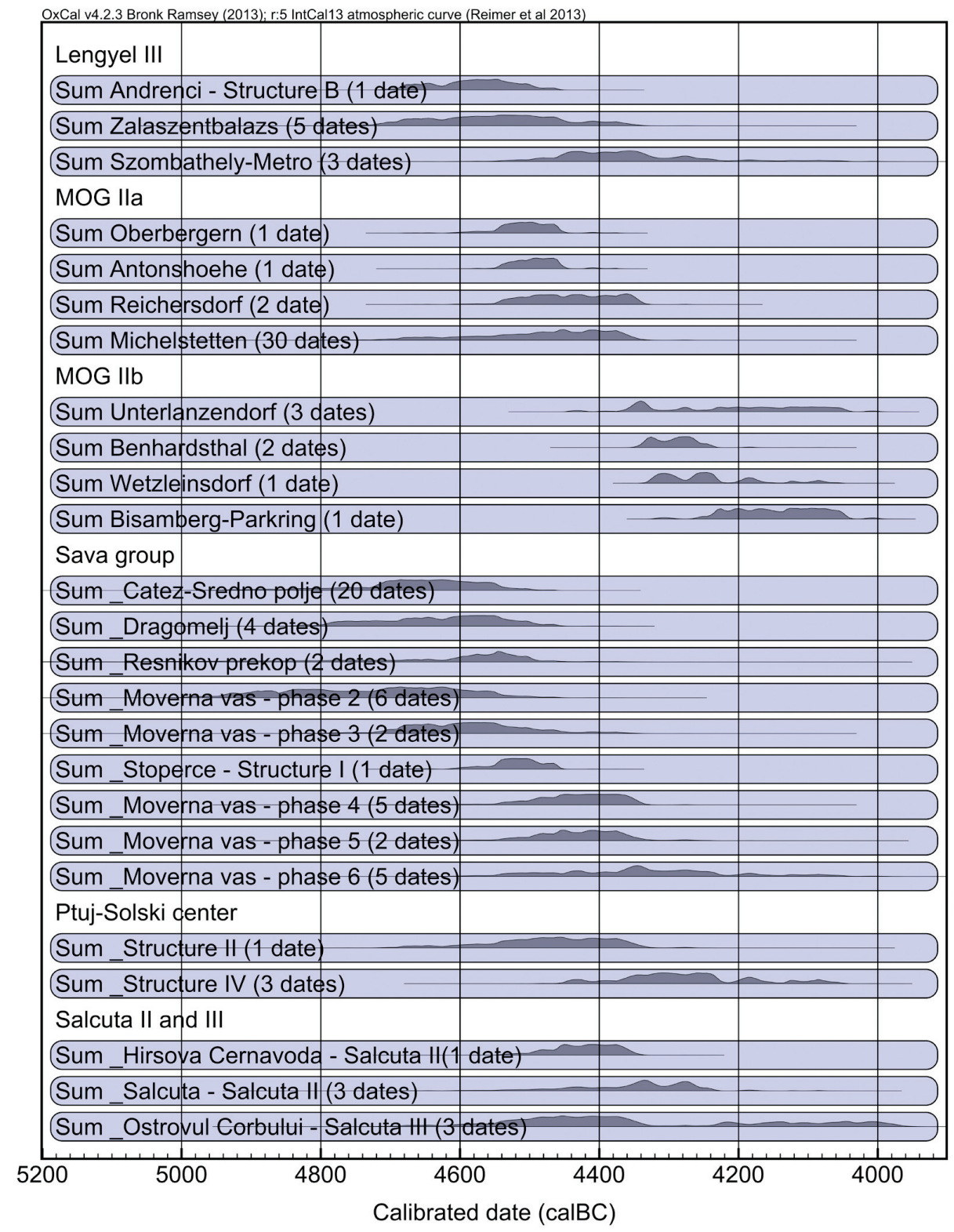

Fig. 35. Sum probability of dates from the sites of Lengyel Phase III (according to Hertelendi 1995.105 and Gábor 2004.Fig. 26), phases MOG IIa and IIb (according to Stadler, Ruttkay 2007.P1. 1-4), the Sava Group and comparable sites in central and south-eastern Slovenia (according to Guštin 2005.Fig. 2; Turk 2010.43; Turk, Svetličič 2005.69; Budja 1994.Fig. 5; Čufar, Korenčič 2006.Pl. 2; Sraka 2012.375), earlier phases of the Salcuta Culture (after Lazarovici, Lazarovici 2013.Fig. 5 and Rădoescu 2009.42) and dates from Ptuj-Šolski center. 


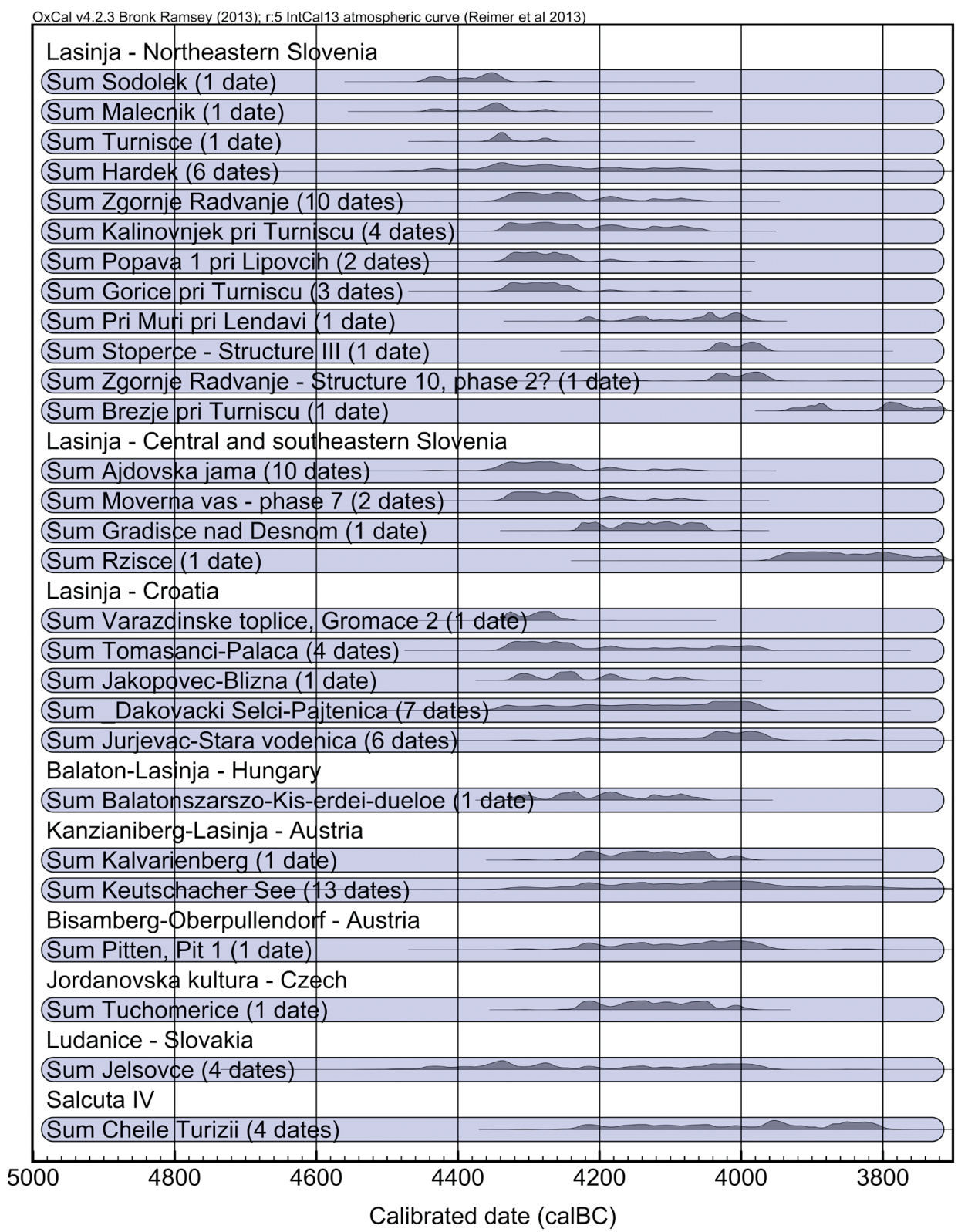

Fig. 36. Sum probability of dates from the Lasinja Culture sites in north-eastern Slovenia (according to Guštin 2005.Fig. 3; Tomaž 2012.Fig. 59; Žižek 2006.Figs. 2 and 3; Kerman 2013.Fig. 46; Savel, Karo 2012.Figs. 48 and 49; Plestenjak 2010.Figs. 86, 93-94; Šavel, Sanković 2011.Fig. 52; Meiert Grootes, Josée Nadeau 2013.126), in central and south-eastern Slovenia (Bonsall et al. 2007.Tab. 1; Mason, Andrič 2009.Tab. 1; Sraka 2013.375) and in Croatia (Bekić 2006.95; 2006a.27; Balen 2008.Fig. 3); a single date of the Balaton-Lasinja Group in Hungary (Oross et al. 2010.Fig. 12); dates of the KanzianibergLasinja Group (Fuchs 2002.117; Cichocki 2003.Tab. 1), Bisamberg-Oberpullendorf Group in Austria (Stadler, Ruttkay 2007.Tab. 4); date of the Jordanovska Culture in the Czech Republic (Sankrot, Zápotocký 2011.114); dates of the Ludanice Group in Slovakia (Görsdorf 1995.205-206) and sum probability of dates from Salcuta Phase IV (according to Lazarovici, Lazarovici 2013.Fig. 5).

Structure II at Ptuj-Šolski center yielded a date that overlaps with the later MOG IIa, with earlier MOG IIb, with dates of the Late Lengyel Culture site at Szombathely metro in Hungary and dates of settlement phases 4 and 5 at Moverna vas (south-eastern Slovenia), which can probably be attributed to the Sava Group (Velušček 2011.226-227). Dates from phases II and III of the Salcuta Culture, where, for example, a comparison of a pot with a rounded lower part was found, are also comparable (Fig. 35).

According to the results of the ${ }^{14} \mathrm{C}$ AMS analyses, structure II at Ptuj-Šolski center is earlier than structures 7, 4, 5, 1, 22, 6 and 10 (Phase 1) at Zgornje Radvanje, and perhaps also Structure IV at Ptuj-Šolski center, although typologically well comparable 
pottery has been discovered in both structures. These structures are earlier than Structure III at Stoperce, part of the site at Radvanje-Habakuk 2 (Arh 2012) and the date from the post-hole SE 1040 at Zgornje Radvanje. Dates from the mentioned structures at Zgornje Radvanje, as well as from Structure IV at Ptuj-Šolski center, are consistent with the earlier dates of the Lasinja Culture and its related cultures in neighbouring countries, while the dates from Structure III at Stoperce (SE 150), part of the site at Radvanje-Habakuk 2 and from post-hole SE 1040 in Zgornje Radvanje, correlate with later dates of the Lasinja Culture and its related cultures. It is important to note that sites with comparable pottery material have been shown to be chronologically concurrent (Keutschacher See, Pri Muri near Lendava and Brezje near Turnišče) (Fig. 36).

\section{Conclusion}

Comparative analyses of pottery found at the studied settlements and beyond, as well as comparisons of radiocarbon dates show that, based on the presented settlements of the $5^{\text {th }}$ millennium BC in northeastern Slovenia, it is possible to identify three cultural groups, i.e. the Sava, the (Late) Lengyel and the Lasinja Culture. According to the current chronology of the 'the central and southern Slovenian Neolithic and Early Eneolithic' and ${ }^{14} \mathrm{C}$ dates known so far, these settlements date to between the Younger/ Late Neolithic and the Early Eneolithic (Velušček 2011.225-23).

Andrenci in western Slovenske gorice represents the extreme south-western site of the Lengyel Culture, while the more or less concurrent Structure I from Stoperce at Haloze belongs to the Sava Group. They are dated to between the end of the $47^{\text {th }}$ century and the first half of the $45^{\text {th }}$ century BC, which is consistent with the earlier dates of the Late Lengyel Culture in western Hungary (Zalaszentbalázs-Szólóhegyi mezó) and dates of MOG IIa in Austria.

The settlement at Ptuj-Šolski center dates to between the end of the 46th and $43^{\text {rd }}$ century BC. 43 The comparative analyses of the pottery are not completely consistent with the relative chronological incorporation of Ptuj-Šolski center into the wider Lengyel Culture (Guštin 2005.13, Fig. 1) or Late Lengyel Culture (Kavur 2010.71). The pottery found in structures (I, II and IV) shows elements of the Sava Group in central and south-eastern Slovenia, as well as elements already attributed to the Early Eneolithic Lasinja Culture. Comparable pottery assemblages are deemed to have been produced in the early phase (Phase I) of the Lasinja Culture in Austria (Tiefengraber 2004. 219).

These phases were followed by the 'Classical' Lasinja Culture. The studied sites passed through two phases: structures 7, 5, 1, 22, 6 and 10 (Phase 1) at Zgornje Radvanje, part of the settlement at Radvanje-Habakuk 2 (Arh 2012.Fig. 10) and the settlement at Hoče-Orglarska delavnica represent the older phase, namely the end of the $44^{\text {th }}$ and $43^{\text {rd }}$ century BC (68.2\% probability), with dates corresponding to earlier (!) dates of the Lasinjska Culture and related cultures in neighbouring areas. Structure IV at PtujŠolski center was more or less contemporaneous, although pottery from this structure is well comparable with material from Structure II on the same site, while its decoration and forms differ slightly from the material found at Zgornje Radvanje and Hoče-Orglarska delavnica. Differences in decorative techniques, motifs and forms could therefore be regional or chronological, but the latter can be confirmed or disproved only with new ${ }^{14} \mathrm{C}$ dates and new pottery assemblages.

The Late Lasinja Culture is presented by pits from the second settlement phase at Stoperce, individual pits in part of the site Radvanje-Habakuk 2 and, according to the ${ }^{14} \mathrm{C}$ date, post-hole SE 1040 at Zgornje Radvanje. This settlement dates to the end of the $5^{\text {th }}$ and the beginning of the $4^{\text {th }}$ millennium $\mathrm{BC}$, where the dates correlate with the later (!) dates of the Lasinja Culture and related cultures in neighbouring countries.

Translation: dr. Nives Kokeza

43 One of the two dates from Structure II was, as already stated, not included in further analyses, as five different samples were mixed in one sample prior to dating. 


\section{ACKNOWLEDGEMENTS}

The paper presents a summary of some of the results of the PhD thesis 'Settlement Structures and Pottery Assemblages in the Fifth Millennium BC in Northeastern Slovenia', which was written under the supervision of prof. dr. Mihael Budja at the Department of Archaeology, Faculty of Arts, University of Ljubljana (Kramberger 2014). I am grateful to archaeologist Marija Lubšina Tušek (ZVKDS, CPA Ptuj), head of archaeological excavations at Stoperce, and in 2000 and 2010 at Ptuj-Šslski center, to retired archaeologist Mira Strmčnik Gulič, head of the archaeological excavations at Zgornje Radvanje, Hoče-Orglarska delavnica and in 1980-1981 at Ptuj-Šolski center, which enabled me to publish this paper. AMS ${ }^{14} \mathrm{C}$ dating of the settlement of Zgornje Radvanje was supported by the Group of Archaeology on the Motorways of the Republic of Slovenia (SAAS) at the Institute for Protection of Cultural Heritage of Slovenia (ZVKDS) and the Motorway Company in the Republic of Slovenia (DARS d.d.).

\section{$\therefore$}

\section{References}

Arh M. 2012. Neo/Eneolitska naselbina Zgornje Radvanje - Habakuk 2. Unpublished undergraduate thesis. University of Ljubljana. Ljubljana.

Artner W., Brandl M., Christandl G., Gutjahr C., Obereder J., Postl W. and Trausner M. 2012. Die kupferzeitliche Höchensiedlung auf der "Kanzel" bei Graz, Steiermark. Fundberichte aus Österreich 50: 43-66.

Balen J. 2008. Apsolutni datumi sa zaštitnih istraživanja na prostoru Slavonije kao prilog poznavanju kronologije srednjeg eneolitika. Vjesnik Arheološkog muzeja u Zagrebu 41(3. ser.): 17-35.

Bánffy E. 1994. Transdanubia and Eastrern Hungary in the Early Copper Age. A Nyíregyházi Jósa András Múzeum Évkönyve 36: 291-295.

1995a. Neolithic and Copper Age settlements at Hahót and Zalaszentbalázs (Zalaszentbalázs-Pusztatetô, HahótSzartóri I-II). Antaeus 22: 35-50.

1995b. Early Chalcolithic settlement at ZalaszentbalázsSzólőhegyi Mező. Antaeus 22: 71-102.

1995c. South West Transdanubia as a mediating area. On the cultural history of the Early and Middle Chalcolithic. Antaeus 22: 157-196.

1997. Cult objects of the Lengyel culture. Connections and interpretation. Archaeolingua Series Minor 7. Archaeolingua Alapítvány. Budapest.

2002. A unique southeastern vessel type from early Chalcolithic Transdanubia: data on the "Western route". Acta Archaeologica Academiae Scientiarum Hungaricae 53: 41-60.

Barna J. P. 2003. Középsố rézkori és késő bronzkori településrészletek Tornyiszentmiklósról. J. Kisfaludi (ed.), Ré- gészeti kutatások Magyarországon 2001/Archaeological investigations in Hungary 2001. Magyar Nemzeti Múzeum. Budapest: 47-62.

Bekić L. 2006. Zaštitna arheologija u okolici Varaždina, Arheološka istraživanja na autocesti Zagreb - Goričan i njezinim prilaznim cestama (S prilozima Darka Komše i Zorka Markovića)/Rescue Archaeology in the Varaždin Environs, Archaeological Research on the Zagreb Goričan Highway and its Access Roads (With Contributions by Darko Komšo and Zorko Marković). Ministry of Culture RH. Zagreb.

Bonsall C., Horvat Mi., McSweeney K., Masson M., Higham T. F. G., Pickard C. and Cook G. T. 2007. Chronological and Dietary Aspects of the Human Burials from Ajdovska cave, Slovenia. Radiocarbon 49(2): 727-740.

Budja M. 1983. Tri desetletja razvoja teorij o poznem neolitu in eneolitu severozahodne Jugoslavije. Poročilo o raziskovanju paleolita, neolita in eneolita $v$ Sloveniji 11: 73-83.

1994. Neolithic Studies in Slovenia: An Overview. Atti della Società per la Preistoria e Protostoria della Regione Friuli - Venezia Giulia 8: 7-28.

1995. Neolithic and Eneolithic settlement patterns in the Bela krajina Region of Slovenia. In A. Aspes (ed.), Symposium Settlement patterns between the Alps and the Black Sea $5^{\text {th }}$ to $2^{\text {nd }}$ millenium B.C. Atti del Siposio Internazionale Modelli Insediativi tra Alpi e Mar Nero dal $5^{\circ}$ al $2^{\circ}$ Millenio A. C., Verona - Lazise 1992. Memore del museo civico di storia naturale di Verona (IIa serie) sezione scienze dell'uomo 4 (1995). Museo civico di storia naturale di Verona. Verona: 119-127.

Bronk Ramsey C. 2009. Dealing with Outliers and offsets in Radiocarbon Dating. Radiocarbon 51(3): 1023-1045. 
Bronk Ramsey C., Lee S. 2013. Recent and planned developments of the program 0xCal. Radiocarbon 55(3-4): $720-730$.

Carneiro A. 2004. Die Interpretation der Keramikfunde von Rabenstein im Lavanttal - Überlegungen zur Lengyelbesiedlung im Südostalpenraum. Carinthia I (194): 185-254.

2006. Die eingetiefte Siedlungskonstruktion von Mannersdorf an der March in Niederösterreich und die eingetieften Bauten der Lengyelkultur. In A. Krenn-Leeb, K. Grömer and P. Stadler (eds.), Archäologie Österreichs 17/02. Festschrift für Elisabeth Ruttkay. Krems/Donau: $71-81$.

Cichocki 0. 2003. Der Pfahlbau im Keutschacher See. In Samonig B., Studien zur Pfahlbauforschung in Österreich Materialen II. Die Pfahlbaustation des Keutschacher Sees. Mitteilungen der Prähistorischen Kommission 51. Österreichische Akademie der Wissenschaften Philosophisch-historische Klasse. Wien: 30-34.

Čufar K., Korenčič T. 2006. Raziskave lesa z Resnikovega prekopa in radiokarbonsko datiranje. In A. Velušček (ed.), Resnikov prekop, najstarejša koliščarska naselbina na Ljubljanskem barju = the oldest Pile-Dwelling Settlement in the Ljubljansko Barje. Opera Instituti Archaeologici Sloveniae 10. Ljubljana: 123-127.

Fuchs G. 2002. Kupferzeitliche Funde vom Kalvarienberg, MG St. Peter am Ottersbach, Steiermark. Fundberichte aus Österreich 40: 115-127.

Gábor I. 2004. Szombathely Óskori településtörténetének vázlata Avagy, a római kor elótt is volt élet/Outline of the Pre-historic settlement of Szombathely or life before the Roman Age. Ôskurunk 2/Our Prehistory, part 2. Headquarter of the Museums in Vas County. Szombathely.

Görsdorf J. 1995. Datierung von Menschenknochen aus dem Gräberfeld Jelšovce. In J. Pavúk and J. Bátora (eds.), Siedlung und gräber der Ludanice-Gruppe in Jelšovce (Mit Beiträgen von J. Jakab, M. Fabiš, L. Illášova, E. Pernicka und J. Görsdorf). Archaeologica Slovaca Monographiae. Studia Instituti Archaeologici Nitriensis Academiae Scientiarum Slovacae 5. Archäologischen Akademie der Wissenschaften. Nitra: 205-209.

Guirao D., Pla F. and Acosta A. 2014. The archaeometric characterization of Majolica ceramics from Talavera de la Reina and El puente del Arzobispo (Toledo, Spain). Archaeometry 56: 746-763.

Guštin M. 2005. Savska skupina lengyelske kulture. In M. Guštin (ed.), Prvi poljedelci, Savska skupina lengyelske kulture/First Farmers, The Sava Group of the Lengyel Culture. Založba Annales (Annales Mediterranea). Koper: 7-22.
Guštin M., Tomaž A. and Kavur B. 2005. Drulovka pri Kranju/Drulovka near Kranj. In M. Guštin (ed.), Prvi poljedelci, Savska skupina lengyelske kulture/First Farmers, The Sava Group of the Lengyel Culture. Založba Annales (Annales Mediterranea). Koper: 37-62.

Hahnel B. 1991. Ein Epilengyel-Brandgrab aus Stillfried in Niederösterreich. Fundberichte aus Österreich 29: 9-12.

Harej Z. 1975. Kolišče ob Resnikovem prekopu - II. Poročilo o raziskovanju neolita in eneolita $v$ Sloveniji 4: 145169.

Hertelendi E. 1995. 14Carbon dating of ZalaszentbálzsSzőlőhegyi Mező (1992-1993). Antaeus 22: 157-196.

Homen Z. 1985. Prilog proučevanju lasinjskih keramičkih bočica. Muzejski vjesnik 8: 44-46.

1990. Lokaliteti Lasinjske Kulture na Križevačkom području/Fundorte der Lasinja-Kultur im gebiet von Križevci. Izdanja Hrvatskog arheološkog društva 14 (1989): 51-68.

Horvat Ma. 1986. Ajdovska jama pri Nemški vasi - desni hodnik. Poročilo o raziskovanju paleolita, neolita in eneolita v Sloveniji 14: 77-88.

Horvat Mi., Horvat Ma. 1987. Ajdovska jama pri Nemški vasi. Varstvo spomenikov 29: 234-236.

Horvat Mi. 1989. Ajdovska jama pri Nemški vasi. Razprave filozofske fakultete. Znanstveni inštitut Filozofske fakultete Ljubljana. Ljubljana.

1999. Keramika. Tehnologija keramike, tipologija lončenine, keramični arhiv. Razprave filozofske fakultete. Znanstveni inštitut Filozofske fakultete Ljubljana. Ljubljana.

2009. Prvi prebivalci v Posavju. In J. Peternel (ed.), Ukročena lepotica. Sava in njene zgodbe. Javni zavod za kulturo, šport, turizem in mladinske dejavnosti. Sevnica: 25-35.

Horváth L., Kalicz N. 2006. Siedlungsfunde der Spätesten phase der Lengyel-Kultur bei Nagykanizsa (südwestungarn) (die Letzten zwei drittel des 5. jahrtausends v. chr., kalibriert). In A. Tomaž (ed.), Od Sopota do Lengyela, prispevki o kamenodobnih in bakrenodobnih kulturah med Savo in Donavo)/Between Sopot and Lengyel, contributions to stone age and copper age cultures between the Sava and the Danube). Založba Annales (Annales Mediterranea). Koper: 53-66.

Horváth L. A., Katalin H. S. 2003. Das Neolithikum und die Kupferzeit in Südwesttransdanubien. Siedlungsge- 
schichte und Forshungsstand. Inventaria Praehistorica Hungariae 8. Magyar Nemzeti Múzeum. Budapest.

2004. Kupferzeitliche Siedlungen auf dem Fundort Dobri-Alsó-mezô. Zalai Múzeum 13: 55-118.

Kalicz N. 1973. Úber die chronologische Stellung der Balaton-Gruppe in Ungarn. In B. Chropovsky (ed.), Symposium über die Entstehung und Chronologie der Badener Kultur. Slowakischen Akademie der Wissenschaften. Bratislava: 131-165.

1975. Siedlungsfunde der Balaton-Gruppe in Nagykanizsa. Mitteilungen des Archäologischen Instituts der Ungarischen Akademie der Wissenschaften 4: 19-24.

1991. Beitrage zur Kenntnis der Kupferzeit im ungarischen Transdanubien. In J. Lichardus (ed.), Die Kupferzeit als historische Epoche. Saarbrücker Beiträge zur Altertumskunde 55(1). Dr. Rudolf Habelt GMBH. Bonn: 347-387.

2003. Az újkőkorvégi és rézkori megtelepedés maradványai a Nagykanizsai Inkey-Kápolna mellett (Kr.e. 5. évezred első harmadától a 3. évezred alsô feléig). $Z a$ lai Múzeum 12: 7-49.

Károlyi M. 1992. A Korai Rézkor Emlékei vas Megyében/ The Early Copper Age in County vas. Ôskorunk 1. Vas Megyei Múzeumok Igazgatósága Szombathely. Szombathely.

Simon Katalin H. 1987. Neolit és rézkori települések Tekenye határán. Zalai Múzeum 1: 7-46.

Kavur B., Tomaž A. and Mileusnić Z. 2006. Sodolek - naselje Bakrene dobe. In A. Tomaž (ed.), Od Sopota do Lengyela, prispevki o kamenodobnih in bakrenodobnih kulturah med Savo in Donavo)/Between Sopot and Lengyel, contributions to stone age and copper age cultures between the Sava and the Danube. Založba Annales (Annales Mediterranea). Koper: 121-128.

Kavur B. 2010. Polomljena kolesa in pozabljene živali. Odsevi predmetov na razpotjih kultur/Broken wheels and forgotten animals. Reflection of artifacts on the crossroads of cultures. Zbornik soboškega muzeja 15: 63-75.

Kavur B., Tušek I. 2011. Ivankovci (Ivánkóc) pri Lenda$v i$. Zbirka Arheologija na avtocestah Slovenije 15, Zavod za varstvo kulturne dediščine Slovenije. Ljubljana.

Kerman B. 2013a. Kalinovnjek pri Turnišču. Zbirka Arheologija na avtocestah Slovenije 33. Zavod za varstvo kulturne dediščine Slovenije. Ljubljana.

2013b. Gornje njive pri dolgi vasi. Zbirka Arheologija na avtocestah Slovenije 36. Zavod za varstvo kulturne dediščine Slovenije. Ljubljana.
Korošec J. 1951. Prazgodovinska naselbina na Ptujskem gradu. Dela/Opera 6. Slovenska akademija znanosti in umetnosti, razred zgodovinske in družbene vede. Ljubljana.

1964. Kulturne ostaline na kolišču ob Resnikovem prekopu odkrite v letu 1962. Poročilo o raziskovanju neolita in eneolita $v$ Sloveniji 1: 25-46.

1965. Neo- in eneolitski elementi na Ptujskem gradu. Poročilo o raziskovanju neolita in eneolita $v$ Sloveniji 2: 5-51.

Korošec Pa. 1975. Poročilo o raziskavah v Ajdovski jami 1967. leta. Poročilo o raziskovanju neolita in eneolita v Sloveniji 4: 170-187.

Koštuřik P. 1979. Neolitické sídliště s malovanu keramikou u Jaroméřice $n$. R. Studie Archaeologického Ústavu Československe Akademie věd v Brně. Academia Praha. Prague.

Kramberger B. 2010a. Neolitska in zgodnjeeneolitska naselbina Zgornje Radvanje, kompleks 10. Unpublished undergraduate thesis. University of Ljubljana. Ljubljana.

2010b. Zgornje Radvanje, Cluster 10 - a Late Neolithic pit with a structure and smaller pits. Documenta Praehistorica 37: 311-338.

2014a. Naselbinske strukture in keramični zbiri v petem tisočletju pred našim štetjem v severovzhodni Sloveniji. Unpublished PhD thesis. University of Ljubljana. Ljubljana.

Krenn-Leeb A. 2006. Chronologietabelle des Neolithikums in Ostösterreich. In A. Krenn-Leeb, K. Grömer and P. Stadler (eds.), Archäologie Österreichs 17(02). Festschrift für Elisabeth Ruttkay. Krems/Donau: 195, Fig. 2.

Kuča M., Schenk Z. and Nývltová Fišáková M. 2011. Lengyelské sídlištê v Dluhonicích (okr. Přerov) a Jeho postavení v rámci počátku mladšîho stupnê Lengyelské Kultury v prostoru Jjižního vstupu Moravské brány (A Lengyel settlement in Dluhonice (Přerov district) and its position with reference to the outset of the later phase of the Lengyel culture in the Southern section of Moravská brána). Acta Musei Moraviae, Scientiae sociales: 33-57.

Lazarovici G., Lazarovici C. - M. 2013. Etapa veche din atelierul de bijuterii de la Cheile Turzii - "Peştera Ungurească". Arheovest I (In Memoriam Liviu Măruia. Interdisciplinaritate in Archaeologie şi Istorie, Timişoar - 7 decembrie 2013): 55-90.

Lubšina Tušek M. 2004. Izročilo preteklosti med Potrčevo in Volkmerjevo cesto na Ptuju. In L. Šuligoj (ed.), Zbornik splošne bolnišnice dr. Jožeta Potrča Ptuj 1874-2004. Ptuj: 73-80. 
Makkay J. 1976. Problems concerning Copper Age chronology in the Carpathian Basin. Acta Archaeologica Academiae Scientiarum Hungaricae 28: 251-300.

Marković Z. 1985. Pogrebni običaji i društveno raslojevanje u neolitu, eneolitu i početku brončanog doba sjeverne Hrvatske. Podravski zbornik 11: 157-167.

1994. Sjeverna Hrvatska od neolita do brončanog doba. Problem stanovništva in kultura sjeverne $\mathrm{Hr}$ vatske od ranog neolita do početka brončanog doba. Muzej Grada Koprivnica. Koprivnica.

Mason P., Andrič M. 2009. Neolithic/eneolithic settlement patterns and Holocene environmental changes in Bela krajina (South-Eastern Slovenia). Documenta Praehistorica 36: 327-335.

Meiert Grootes P., Josée Nadeau M. 2013. Radiocarbon ${ }^{14} \mathrm{C}$ analysis. In Novšak M., Tomaž A. and Plestenjak A. (eds.), Brezje pri Turnišču. Zbirka Arheologija na avtocestah Slovenije. Zavod za varstvo kulturne dediščine Slovenije 40. Ljubljana: 126-127.

Mlekuž D., Ogrinc N., Horvat Mi., Žibrat Gašparič A., Gams Petrišič M. and Budja M. 2013. Pots and food: uses of pottery from Resnikov prekop. Documenta Praehistorica 40: $131-146$.

Murko M. 2012. Maribor - arheološko najdišče Zgornje Radvanje. Varstvo spomenikov 47: 139-142.

Neugebauer J. W., Neugebauer-Maresch C. 2003. Die Doppel-Sonderbestattung der Bemaltkeramik von Reichersdorf, Marktgemeinde Nussdorf ob der Traisen, Niederösterreich. In E. Jerem, P. Raczky (eds.), Morgenrot der Kulturen. Frühe Etappen der Menschheitsgeschichte in Mittel- und Südosteuropa. Festschrift für Nándor Kalicz zum 75. Geburtstag, Archaeolingua 15. Archaeolingua Alapítvány. Budapest: 327-334.

Novšak M., Tomaž A. and Plestenjak A. 2013. Brezje pri Turnišču. Zbirka Arheologija na avtocestah Slovenije. Zavod za varstvo kulturne dediščine Slovenije 40. Ljubljana.

Obelić B., Bronić I. K. and Horvatinčić N. 2002. Rudjer Bošković Institue radiocarbon measurements XV. Radiocarbon 44(2): 601-630.

Obereder J. 1989. Die jungneolitische Siedlung Raababerg bei Graz. Unpublished undergraduate thesis. University of Vienna. Vienna.

Oross K., Marton T., Whittle A., Hedges R. E. M. and Cramp L. J. E. 2010. Die Siedlung der Balaton-Lasinja-Kultur in Balatonszárzo-Kis-erdei-dôlő. In J. Sutekova, P. Pavuk, P. Kalabkova and B. Kovar (eds.), Panta Rhei: Studies in Chronology and Cultural Development of South-
Eastern and Central Europe in Earlier Prehistory Presented to Juraj Pavuik on the Occasion of his $75^{\text {th }}$ Birthday. Studia Archaeologica et Mediaevalia 11. Comenius University in Bratislava. Bratislava: 381-407.

Pahič S., Lorber V. 1954. Andrenški vrh. Arheološki vestnik 5/2: 335-360.

Pahič S. 1956. Neolitske jame v Brezju pri Zrečah. Arheološki vestnik 7/2: 227-241.

1973. Najstarejše seliščne najdbe v severovzhodni Sloveniji. Arheološki vestnik 24: 12-30.

1976. Seliščne najdbe v zahodnih Slovenskih goricah Andrenci, Spodnji Duplek, Spodnji Porčič, Vumpah. Poročilo o raziskovanju paleolita, neolita in eneolita $v$ Sloveniji 5: 29-83.

Pahič V. 1983. Zbelovo. Poročilo o raziskovanju paleolita, neolita in eneolita $v$ Sloveniji 11: 85-137.

Plestenjak A. 2010. Gorice pri Turnišču. Zbirka Arheologija na avtocestah Slovenije 12. Zavod za varstvo kulturne dediščine Slovenije. Ljubljana.

Raczky P. 1974. A Lengyeli kultúra legkésóbbi szakaszának leletei a dunántúlon/Funde der spätesten phase der Lengyel-kultur in Westungarn. Archaeologiai Értestitó 101: $185-210$.

Radu A. 2002. Cultura Sălcuţa în Banat. Editura Banatica. Timişoara.

Rădoescu L. 2009. Câteva considerații cu privire la evoluţia şi chronologia culturii Sălcuţa. Analele Universită tii "Constantin Brâncuşi" din Târgu Jiu, Seria Litere şi Stiintse Sociale 2(2009): 33-44.

Rakovsky I. 1986. Die Neige der Ältern Stüfe der Kultur mit mährischer bemalter Keramik im Lichte der funde aus Jezerany-Maršovice und Brno-Bystrc. In B. Chropowsky, H. Friesinger (eds.), Internationales symposium über der Lengyel-Kultur (Nové Vozokany). Archäologisches Institut der Slowakischen Akademie der Wissenshaften. Nitra-Wien: 243-250.

Regenye J. 1994. Előzetes jelentés a Lengyeli kultúra Szentgáli Telepének Kutatásáról. A Veszprém Megyei Múzeumok Közleményei 19-20: 69-88.

2006. Kaposvár-Gyertyános, die Siedlung der Lengyel-Kultur. In A. Tomaž (ed.), Od Sopota do Lengyela, prispevki o kamenodobnih in bakrenodobnih kulturah med Savo in Donavo/Between Sopot and Lengyel, contributions to stone age and copper age cultures between the Sava and the Danube. Založba Annales (Annales Mediterranea). Koper: 67-74. 
2007. The Late Lengyel culture in Hungary as reflected by the excevation at Veszprém. In J. K. Kozłovski, P. Raczky (eds.), The Lengyel, Polgár and related cultures in the Middle/Late Neolithic in Central Europe. The Polish Academy of Arts and Sciences Kraków, Eötvös Loránd University Institute of Archaeological Sciences Budapest. Kraków: 381-396.

Reimer P. J. and 29 authors 2013. IntCal13 and Marine13 radiocarbon age calibration curves, 0-50,000 years cal BP. Radiocarbon 55(4): 1869-1887.

Rice P. M. 1987. Pottery Analysis, A Sourcebook. The University of Chicago Press. Chicago, London.

Ruttkay E. 1976. Die Keramikformen der Lengyel-Kultur in Österreich. Fundberichte aus Österreich 15: 141-148.

1994. Neues Tonstempel der Kanzianiberg-Lasinja-Gruppe. Mitteilungen der Antropologischen Gesellschaft in Wien 123/124: 221-238.

Samogyi K. 2000. A Balaton-Lasinja-Kultúra Leletanyaga Somogy Megyében. Communicationes Archaeologicae Hungariae 2000: 5-48.

Samonig B. 2003. Studien zur Pfahlbauforschung in Österreich Materialen II. Die Pfahlbaustation des Keutschacher Sees. Mitteilungen der Prähistorischen Kommission 51. Österreichische Akademie der Wissenschaften Philosophisch-historische Klasse. Wien.

Sankrot P. and Zápotocký M. 2011. Eneolitický sídlištní areál (jordanovská a řivnáčská kultura) s kruhovým objektem - rondelem v Tuchoměřcíh, okr. Praha-západ (Das äneolithische Siedlungsareal der Jordanóv- und ŘivnáčKultur mit Rondell in Tuchoměřice, Landkr. Prag-West). Památky Archeologické 52: 59-116.

Sraka M. 2012. ${ }^{14} \mathrm{C}$ calendar chronologies and cultural sequences in $5^{\text {th }}$ millennium cal BC in Slovenia and neighbouring regions. Documenta Praehistorica 39: 349-376.

2013. 14C dates and stratigraphy: reconsidering the sequences at Moverna vas (Bela Krajina, southeastern Slovenia). Documenta Praehistorica 40: 313-321.

Stadler P., Ruttkay E. 2007. Absolute chronology of the Moravian-Eastern-Austrian Group (MOG) of the painted pottery (Lengyel-culture) based on new radiocarbon dates from Austria. In J. K. Kozłovski, P. Raczky (eds.), The Lengyel, Polgár and related cultures in the Middle/Late Neolithic in Central Europe. The Polish Academy of Arts and Sciences Kraków, Eötvös Loránd University Institute of Archaeological Sciences Budapest. Kraków: 117-146.

Straub P. 2006. Középső rézkori település Sormás határában/Middle Copper Age settlement at Sormás. J. Kisfaludi (ed.), Régészeti kutatások Magyarországon 2005/Archaeological investigations in Hungary 2005. Magyar Nemzeti Múzeum. Budapest: 33-60.

Strmčnik Gulič M. 1983. Ptuj. Varstvo spomenikov 25: 193.

1989. Hoče. Varstvo spomenikov 31: 224-226.

1990. Hoče. Varstvo spomenikov 32: 173-175.

Šavel I. 1984. Poročilo o raziskovanju od leta 1981 do 1983 v Šafarskem. Poročilo o raziskovanju paleolita, neolita in eneolita $v$ Sloveniji 12: 39-72.

1992. Bukovnica - rezultati terenskih raziskav v letih 1987-1988. Poročilo o raziskovanju paleolita, neolita in eneolita $v$ Sloveniji 20: 57-85.

1994. Prazgodovinske naselbine v Pomurju. Pomurska založba. Murska Sobota.

2006. Prekmurje v mlajši kameni dobi. In A. Tomaž (ed.), Od Sopota do Lengyela, prispevki o kamenodobnih in bakrenodobnih kulturah med Savo in Donavo/Between Sopot and Lengyel, contributions to stone age and copper age cultures between the Sava and the Danube. Založba Annales (Annales Mediterranea). Koper: 89-94.

2009. Pod Kotom - jug pri Krogu I/II. Zbirka Arheologija na avtocestah Slovenije 7 . Zavod za varstvo kulturne dediščine Slovenije. Ljubljana.

Šavel I., Karo Š. 2012. Popava pri Lipovcih 1. Zbirka Arheologija na avtocestah Slovenije 30. Zavod za varstvo kulturne dediščine Slovenije. Ljubljana.

Šavel I., Sankovič S. 2011. Pri Muri pri Lendavi. Zbirka Arheologija na avtocestah Slovenije. Zavod za varstvo kulturne dediščine Slovenije 23. Ljubljana.

Tiefengraber G. 2004. Jungneolithische Funde vom Rabenstein bei St. Paul im Lavanttal. Carinthia I (194): 185-254.

2006a. Zum Forschungsstand des Neolithikums in der Steiermark. In A. Tomaž (ed.), Od Sopota do Lengyela, prispevki o kamenodobnih in bakrenodobnih kulturah med Savo in Donavo)/Between Sopot and Lengyel, contributions to stone age and copper age cultures between the Sava and the Danube. Založba Annales (Annales Mediterranea). Koper: 81-88.

2006b. Jungneolitische funde aus Čatež-Sredno polje. In A. Tomaž (ed.), Od Sopota do Lengyela, prispevki o kamenodobnih in bakrenodobnih kulturah med Savo in Donavo)/Between Sopot and Lengyel, contributions to stone age and copper age cultures between 
the Sava and the Danube. Založba Annales (Annales Mediterranea). Koper: 229-234.

Tomanič-Jevremov M., Tomaž A. and Kavur B. 2006a. Ormož-Škoršičev vrt. In A. Tomaž (ed.), Od Sopota do Lengyela, prispevki o kamenodobnih in bakrenodobnih kulturah med Savo in Donavo)/Between Sopot and Lengyel, contributions to stone age and copper age cultures between the Sava and the Danube. Založba Annales (Annales Mediterranea). Koper: 155-174.

2006b. Neolitske in bakrenodobne najdbe s Ptujskega gradu. In A. Tomaž (ur.), Od Sopota do Lengyela, prispevki o kamenodobnih in bakrenodobnih kulturah med Savo in Donavo)/Between Sopot and Lengyel, contributions to stone age and copper age cultures between the Sava and the Danube. Založba Annales (Annales Mediterranea). Koper: 175-194.

Tomaž A. 1999. Časovna in prostorska strukturiranost neolitskega lončarstva: Bela krajina, Ljubljansko barje, Dinarski kras. Unpublished undergraduate thesis. University of Ljubljana. Ljubljana.

2010. Neolitska keramika iz najdišča Čatež-Sredno polje: prispevek $k$ poznavanju neolitskega obdobja $v$ osrednji Sloveniji. Unpublished $\mathrm{PhD}$ thesis. University of Primorska. Koper.

2012. Turnišče. Zbirka Arheologija na avtocestah Slovenije 28 . Zavod za varstvo kulturne dediščine Slovenije. Ljubljana.

Tomaž A., Kavur B. 2006. Zemlja in ogenj. Univerza na Primorskem. Založba Annales (Annales Mediterranea). Koper.

Turk P. 2010. Priložnosti in pasti radiokarbonske datacije iz neolitske naselbine v Dragomlju. Argo 53/1: 41-44.

Turk P., Svetličič V. 2005. Neolitska naselbina v Dragomlju. In M. Guštin (ed.), Prvi poljedelci, Savska skupina lengyelske kulture/First Farmers, The Sava Group of the Lengyel Culture. Založba Annales (Annales Mediterranea). Koper: 65-79.

Tušek I. 1999. Hardek. Varstvo spomenikov 38: 35-46.

Velušček A. 2005. Kratna nad Kamnikom, Gradišče pri Stiški vasi. In M. Guštin (ed.), Prvi poljedelci, Savska skupina lengyelske kulture/First Farmers, The Sava Group of the Lengyel Culture. Založba Annales (Annales Mediterranea). Koper: 23-28.

2006. Resnikov prekop - sondiranje, arheološke najdbe, kulturna opredelitev in časovna uvrstitev. In A. Velušček (ed.), Resnikov prekop, najstarejša koliščarska naselbina na Ljubljanskem barju = the oldest Pile-
Dwelling Settlement in the Ljubljansko Barje. Opera Instituti Archaeologici Sloveniae 10. Ljubljana: 19-86.

2011. Spaha in kronologija osrednje- in južnoslovenskega neolitika ter zgodnejšega eneolitika/Spaha and chronology of central and south Slovenian Neolithic and Early Eneolithic. In A. Velušček (ed.), Spaha. Opera Instituti Archaeologici Sloveniae 22. Ljubljana: 201244.

Virág S. 2003a. Settlement historical research in Transdanubia in the first half of the Middle Copper Age. In E. Jerem, P. Raczky (eds.), Morgenrot der Kulturen. Frühe Etappen der Menschheitsgeschichte in Mittel- und Südosteuropa. Festschrift für Nándor Kalicz zum 75. Geburtstag, Archaeolingua 15. Archaeolingua Alapítvány. Budapest: 375-400.

Virág S. M. 2003b. Középső rézkori kerámialeletek Zalavár-Basaszigetrốl. A Balaton-Lasinja kultúra tipológiájának és belsố kronológiájának kérdéseiról. Zalai Múzeum: 3752 .

Virág Z. M., Figler A. 2007. Data on the settlement history of the Late Lengyel period of Transdanubia on the basis of two sites from the Kisalföld (small Hungarian plain). A preliminary evaluation of the sites Gyôr-Szabadrétdomb and Mosonszentmiklós-Pálmajor. In J. K. Kozłovski, P. Raczky (eds.), The Lengyel, Polgár and related cultures in the Middle/Late Neolithic in Central Europe. The Polish Academy of Arts and Sciences Kraków, Eötvös Loránd University Institute of Archaeological Sciences Budapest. Kraków: 345-364.

Wiener M. H. 2012. Problems in the measurement, calibration, analysis, and communication of radicarbon dates (with special reference to the prehistory of the aegean world. Radiocarbon 54(3-4): 423-434.

Zalai-Gaál I. 1982. A lengyeli kultúra kronológiai kérdései a Dél-Dunántúlon. A Szekszárdi Béri Balogh Ádám Múzeum Évkönyve 10-11: 3-58.

2003. Das Henkelgefäß aus Györe: Ein Beitrag zu den chronologischen und kulturellen Beziehungen der Lengyel-Kultur. In E. Jerem, P. Raczky (eds.), Morgenrot der Kulturen. Frühe Etappen der Menschheitsgeschichte in Mittel- und Südosteuropa. Festschrift für Nándor Kalicz zum 75. Geburtstag, Archaeolingua 15. Archaeolingua Alapítvány. Budapest: 285-310.

Žižek I. 2006a. Eneolitska naselbina Hardek. In A. Tomaž (ed.), Od Sopota do Lengyela, prispevki o kamenodobnih in bakrenodobnih kulturah med Savo in Donavo)/ Between Sopot and Lengyel, contributions to stone age and copper age cultures between the Sava and the Danube. Založba Annales (Annales Mediterranea). Koper: 129-140. 

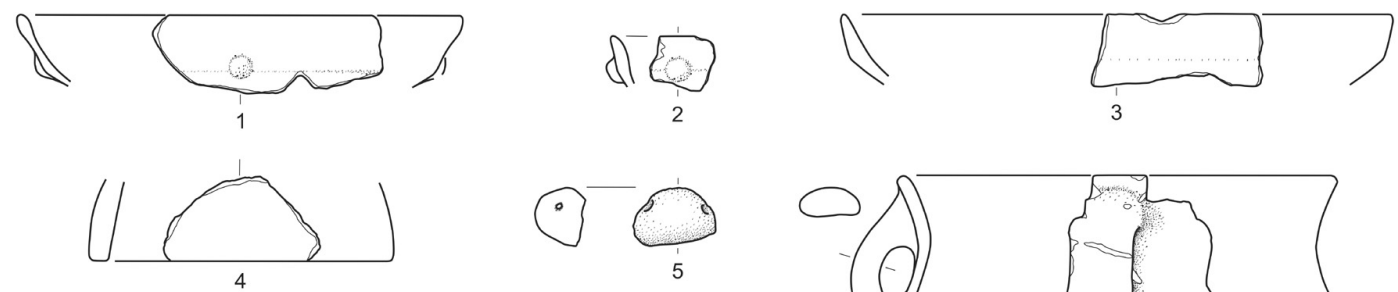

(2)
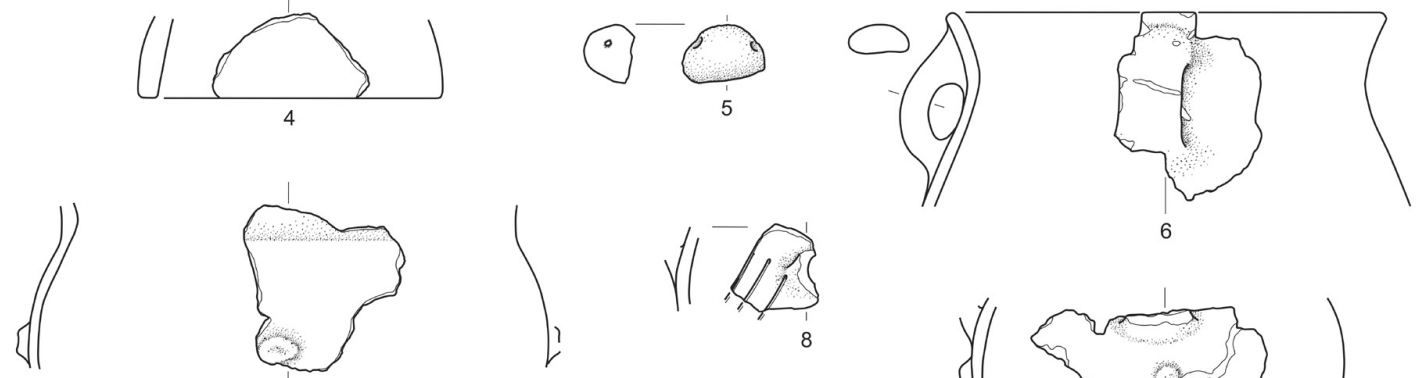

i $\quad \sqrt{1}$

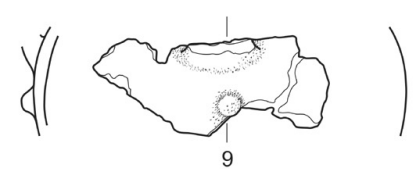

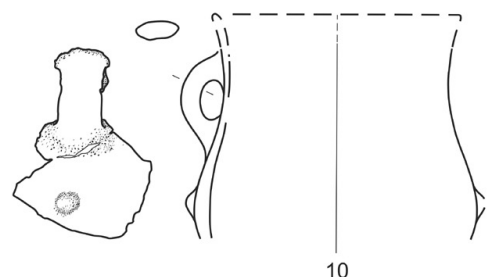

$\mathrm{A} 1$ and $\mathrm{A} 2$
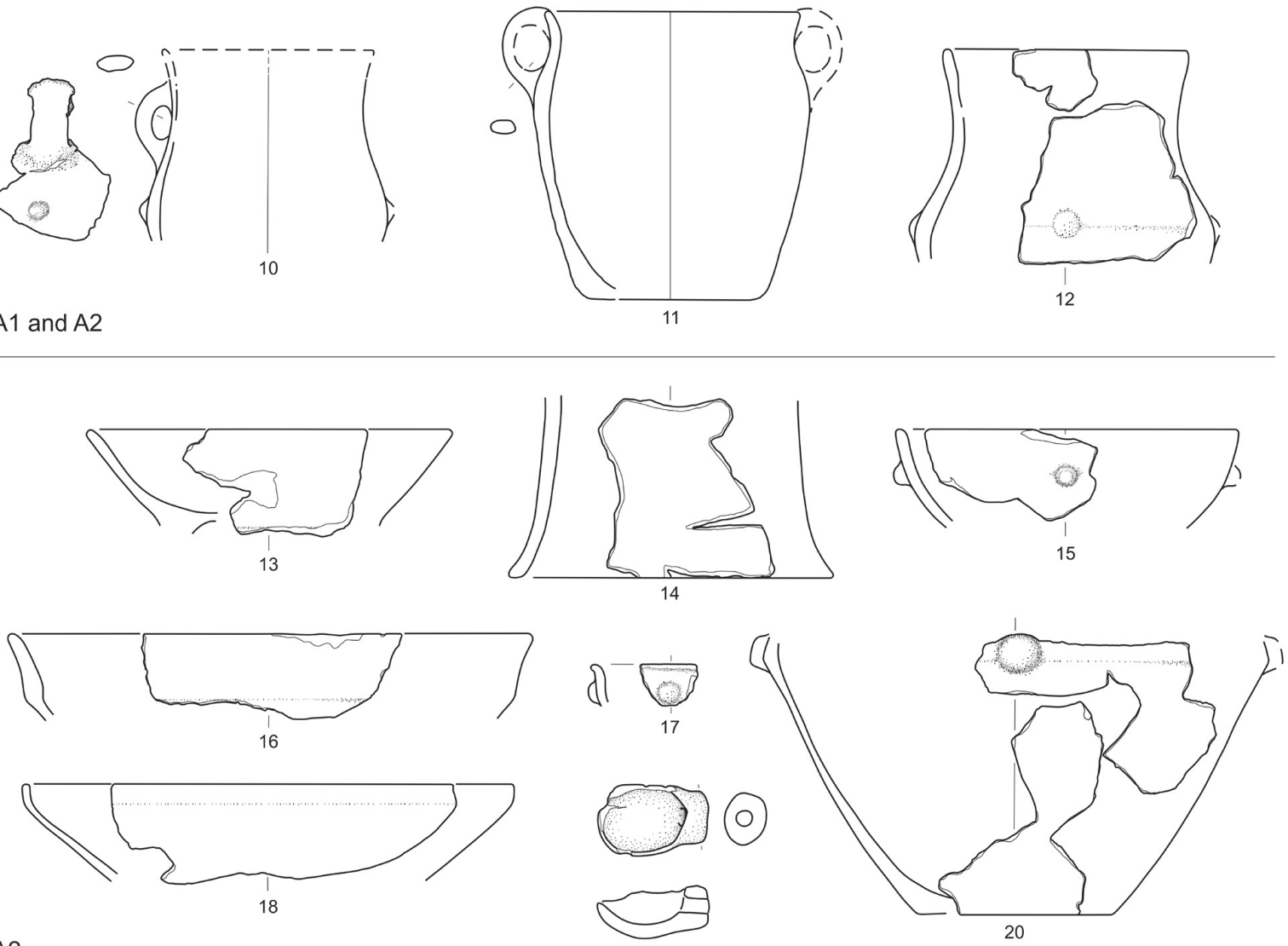

A2
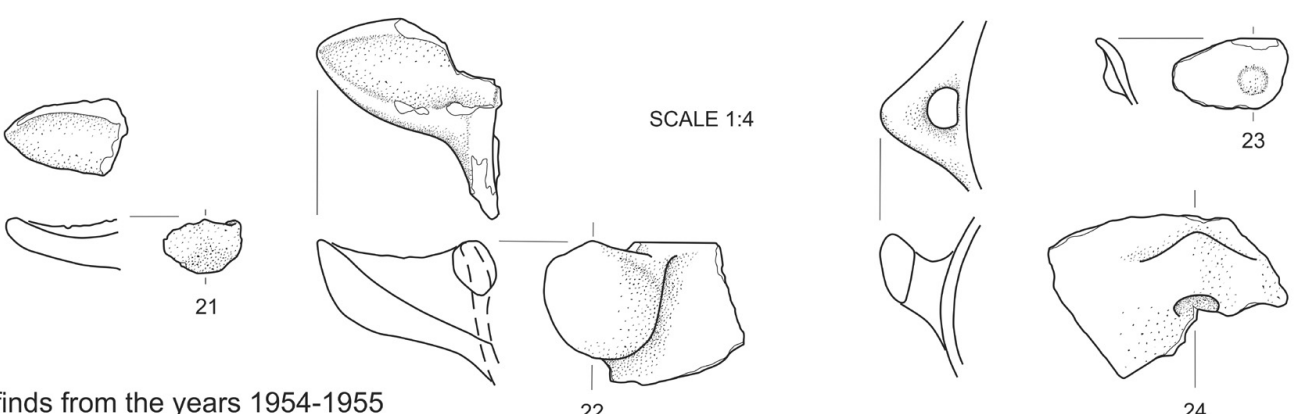

24

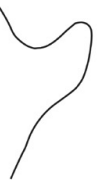

finds from the years 1954-1955

Pl. 1. Andrenci. Structure A - layer A1, layer A2 and finds from 1954-1955. Pottery. 
$7 \underbrace{2}_{25}$

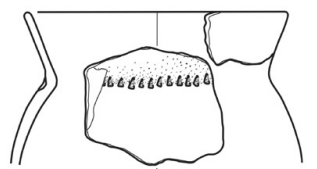

28

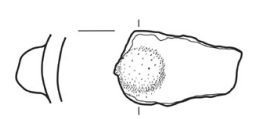

32
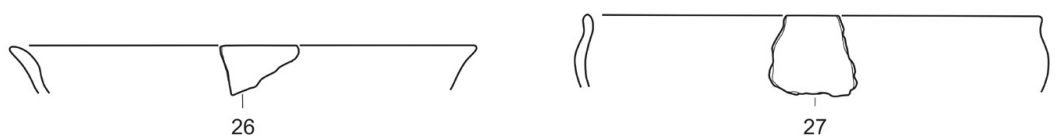

$4 \sqrt{29} d \sqrt{30}$
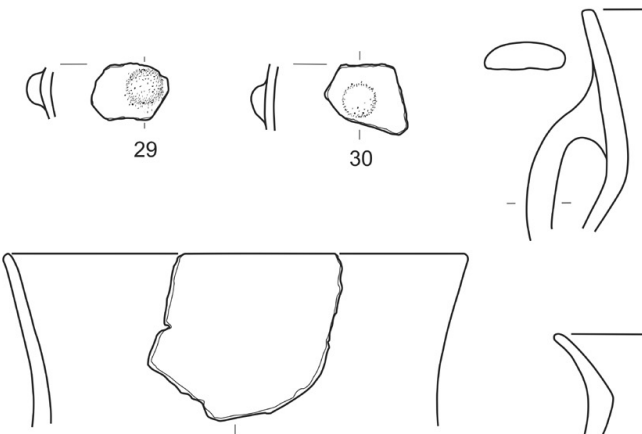

33

B1
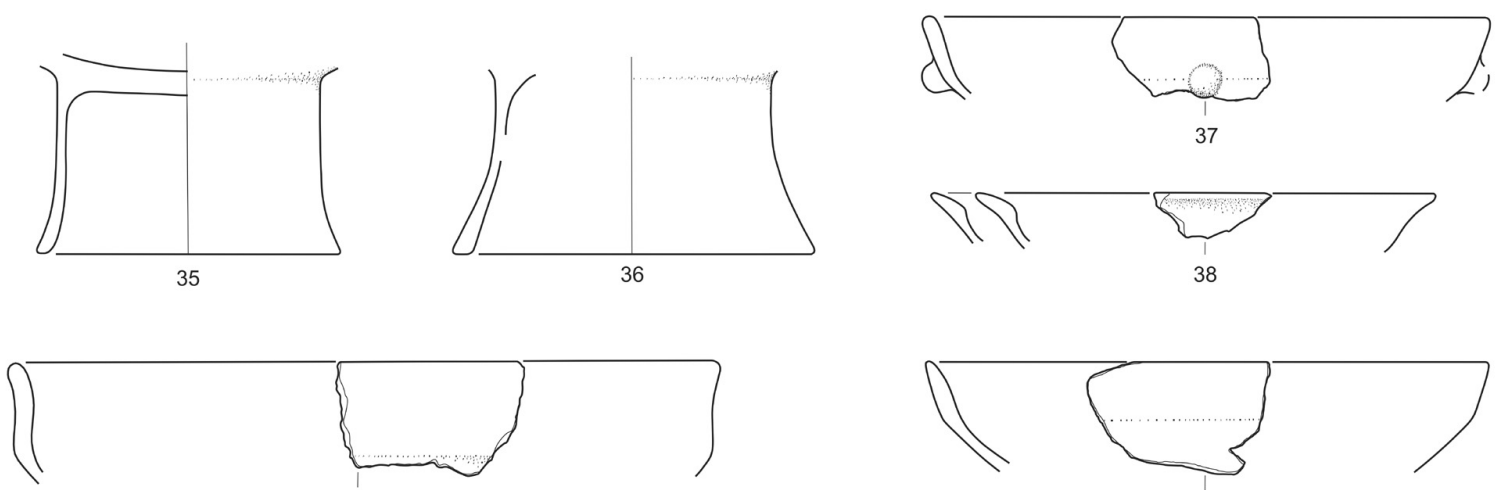

39
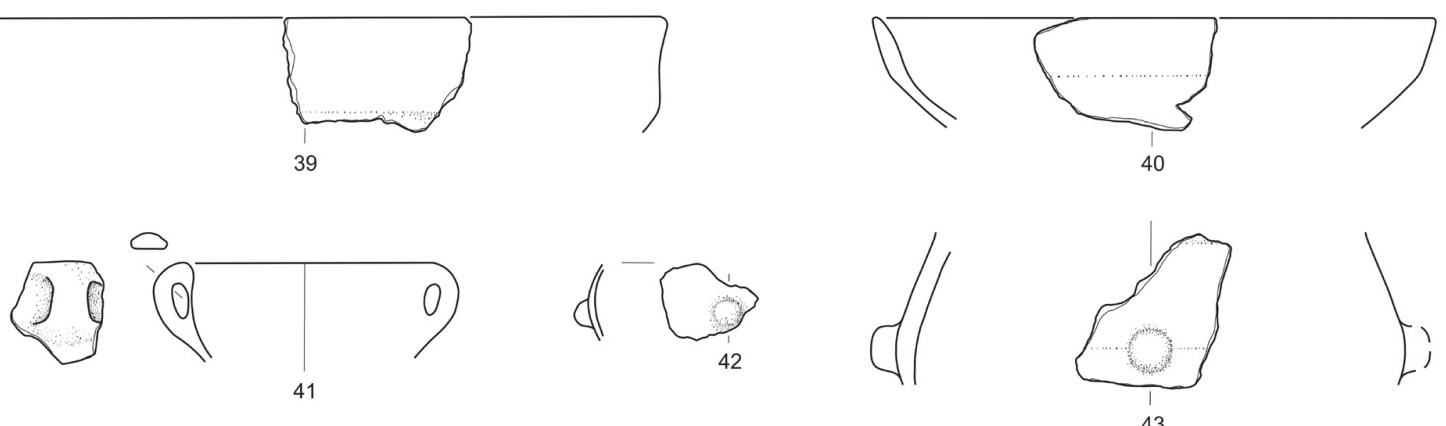

43

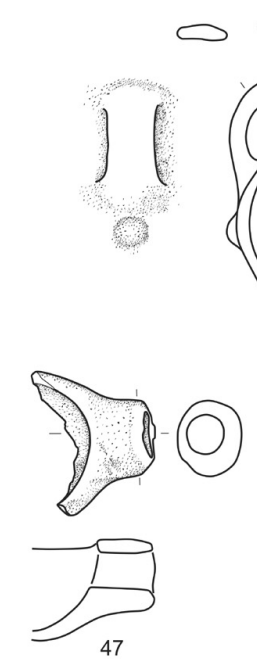

B2
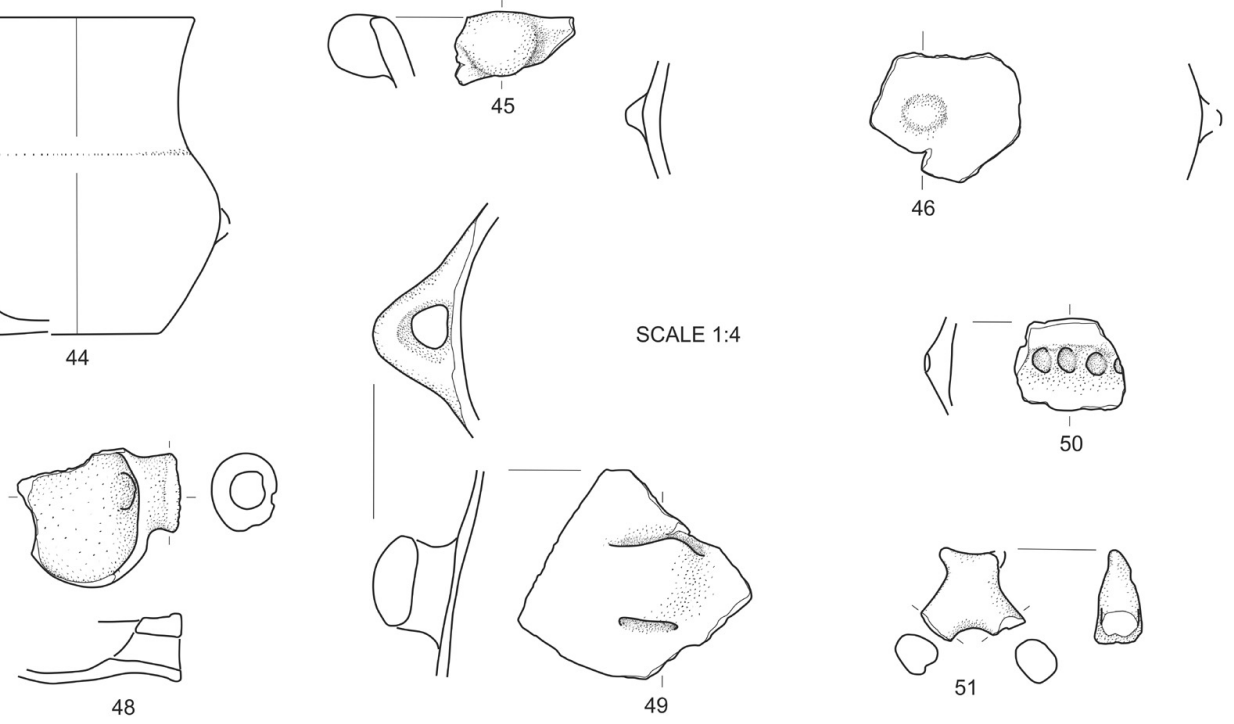

Pl. 2. Andrenci. Structure B - layer B1 and layer B2. Pottery. 

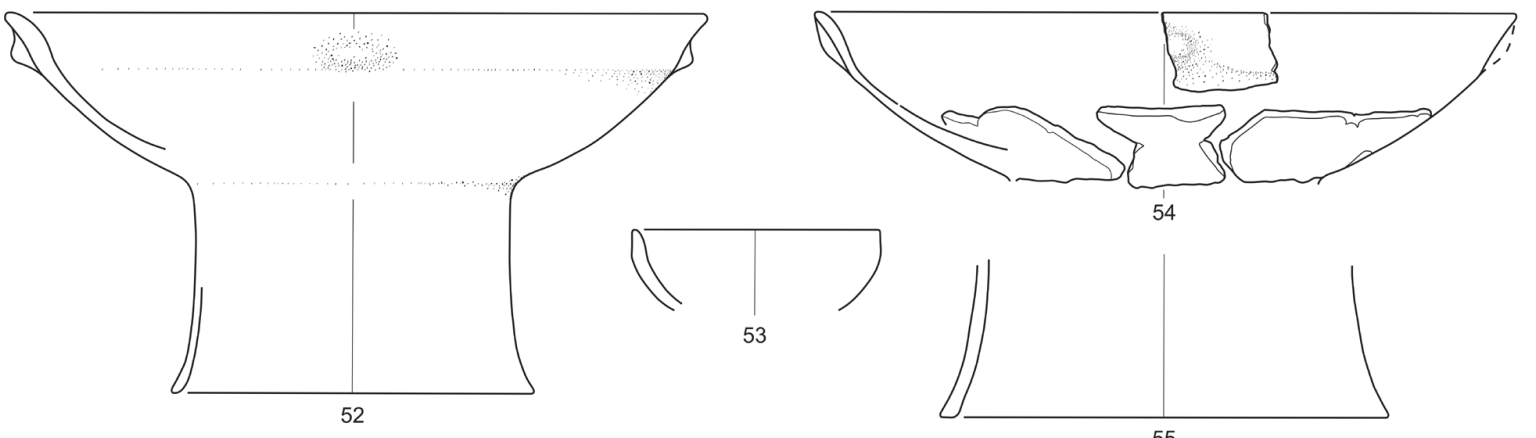

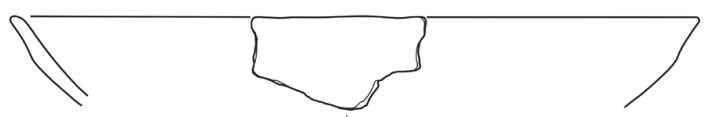

56

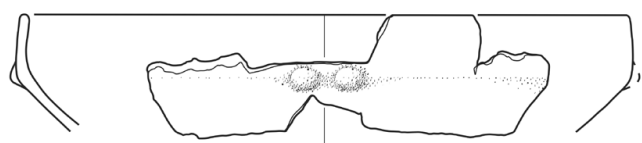

58

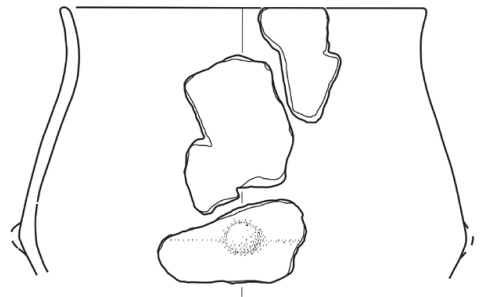

60

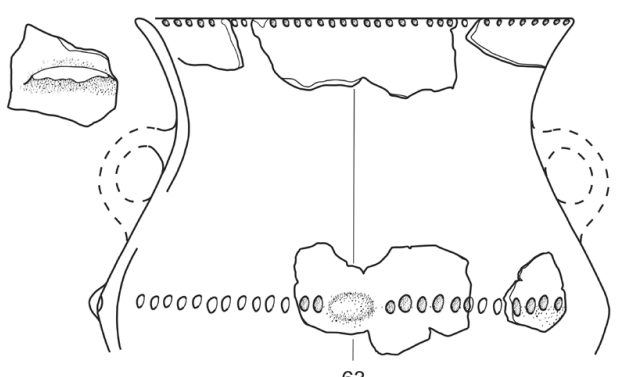

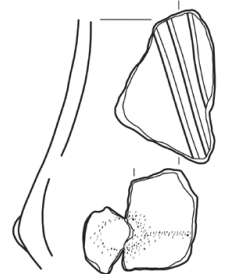

65

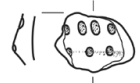

66

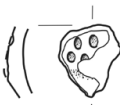

67

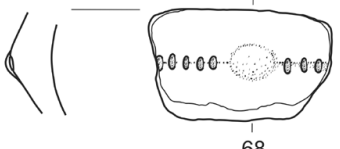

68

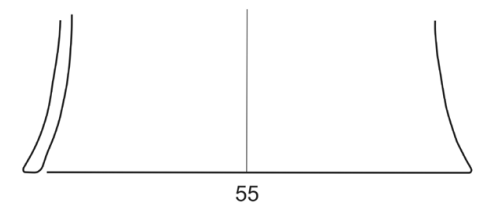

SCALE 1:4
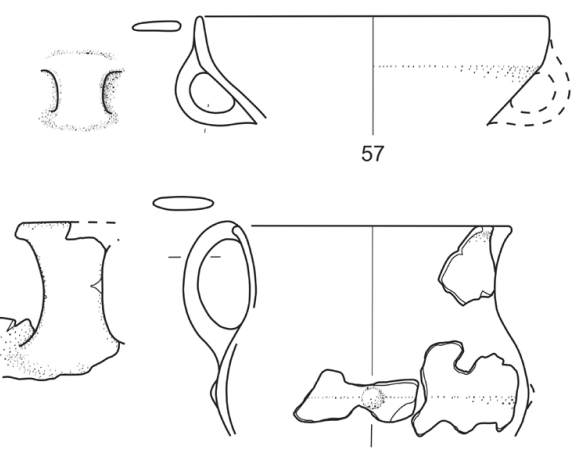

59

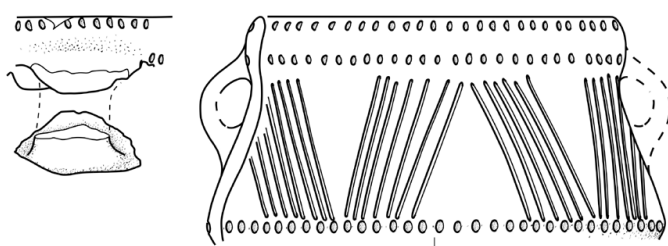

62

) 10000

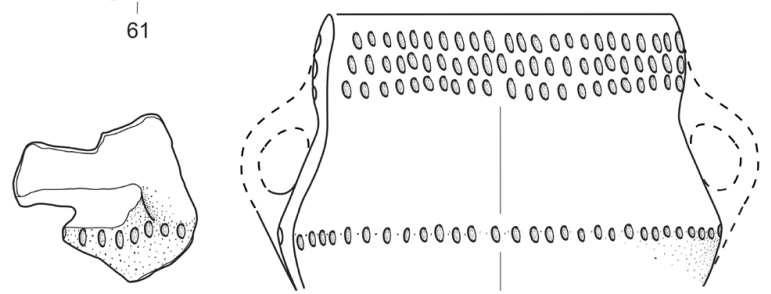

64

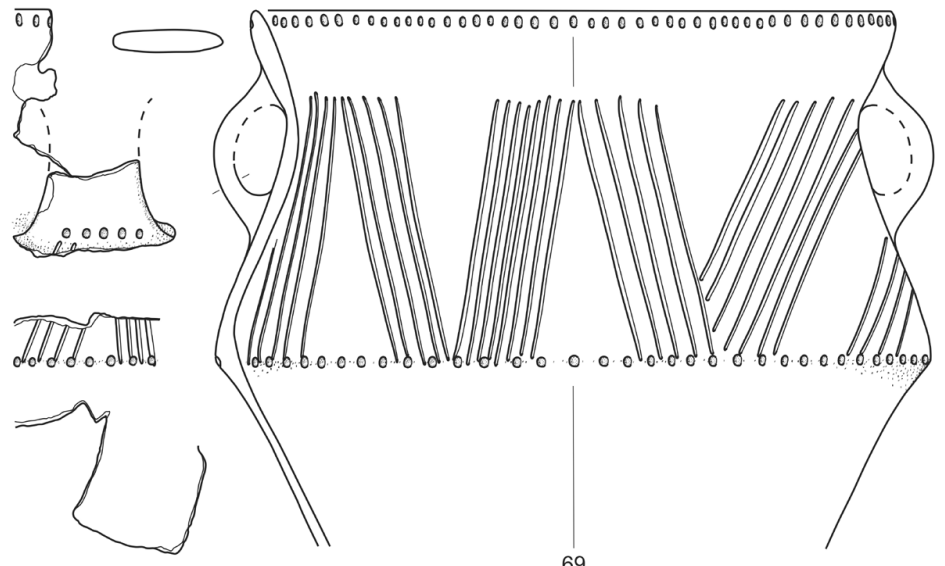

Pl. 3. Stoperce. Structure I - layer SE 128. Pottery. 


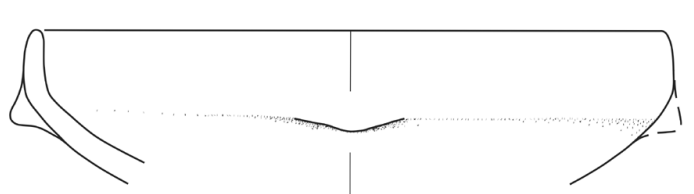

70

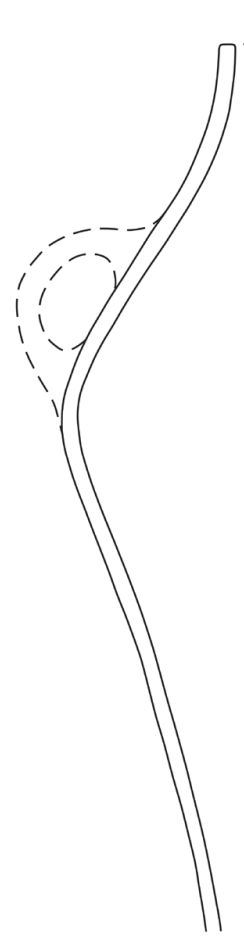

Structure III - SE 150

72

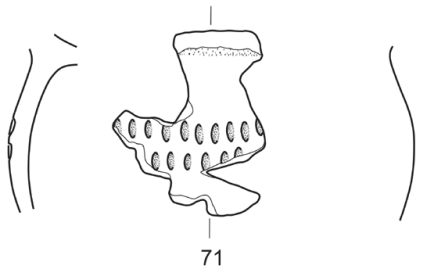

SCALE 1:4
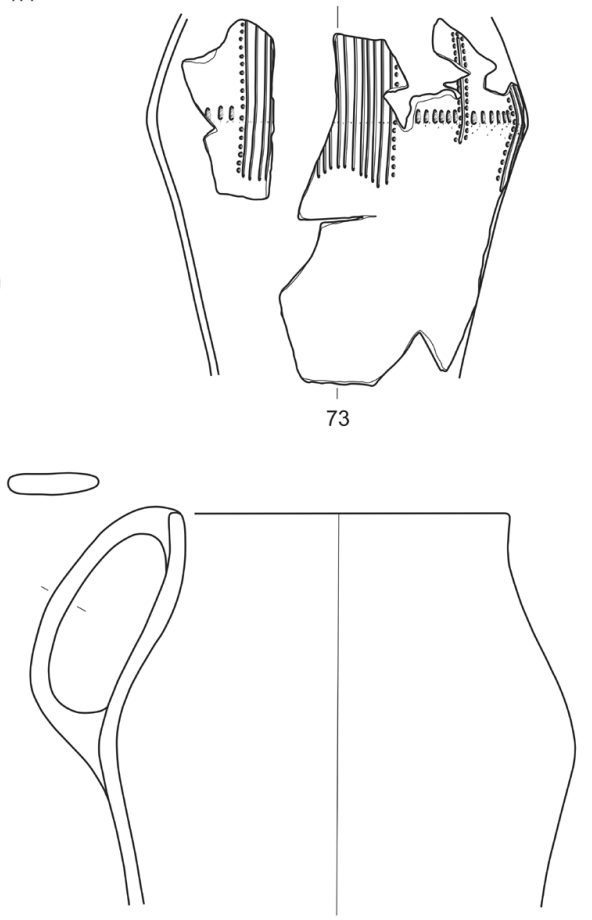

74

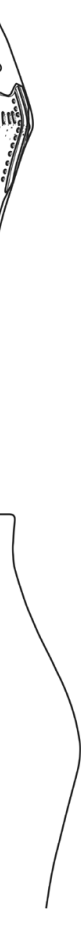

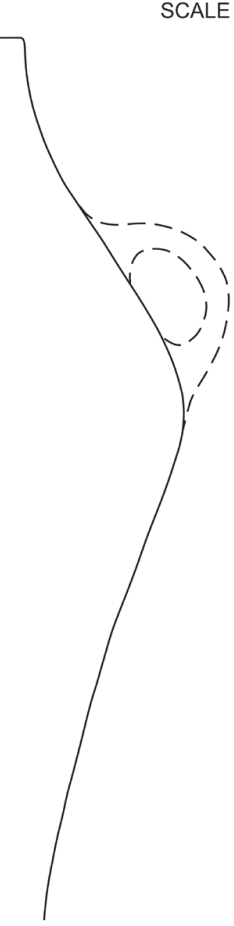
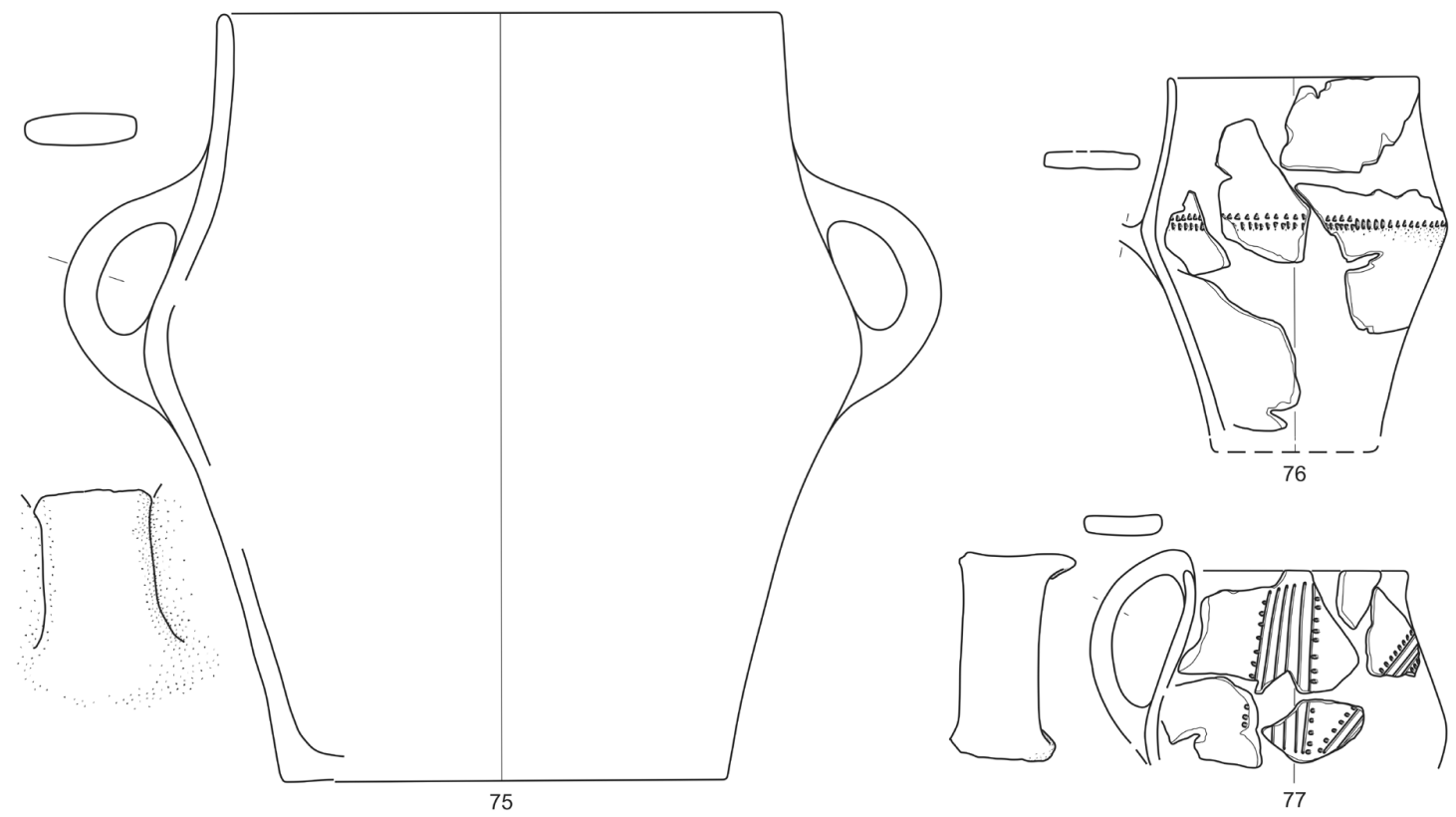

SE 52

Pl. 4. Stoperce. Structure III - layer SE 150. Pit SE 52. Pottery. 


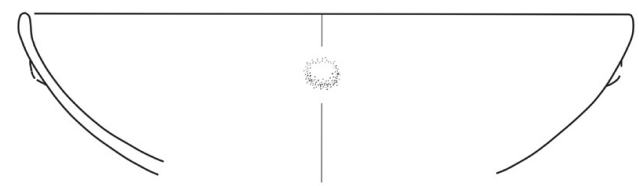

78
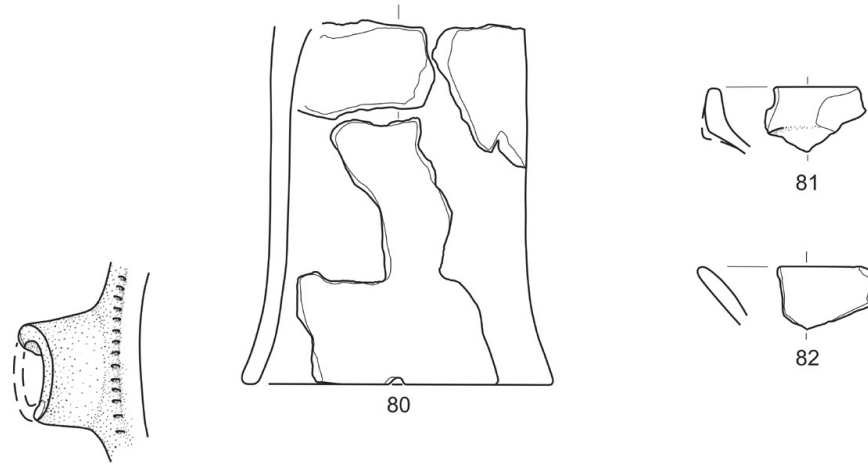

81

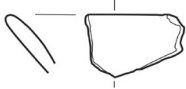

82

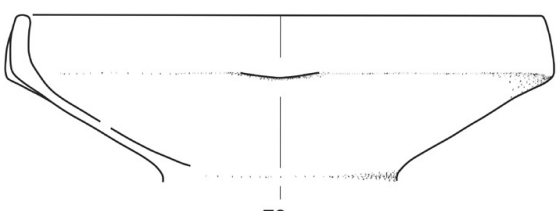

79

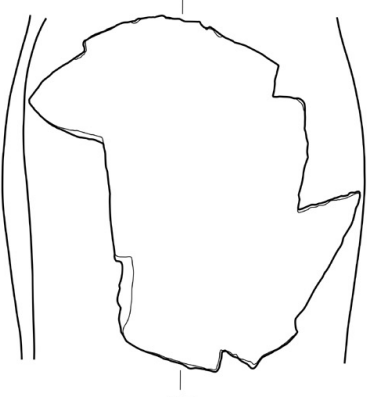

83

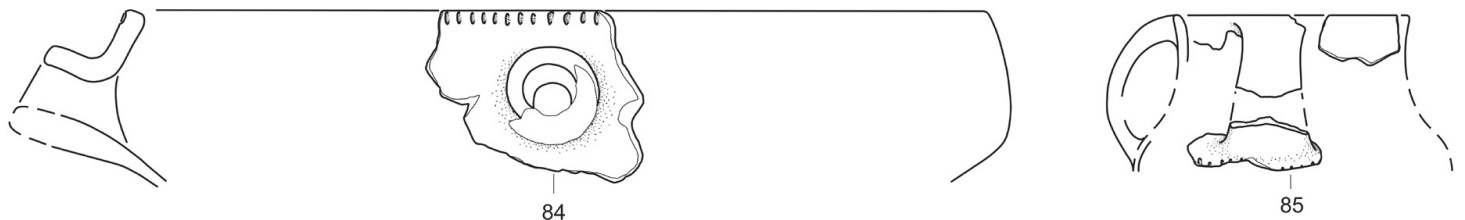

SE 410
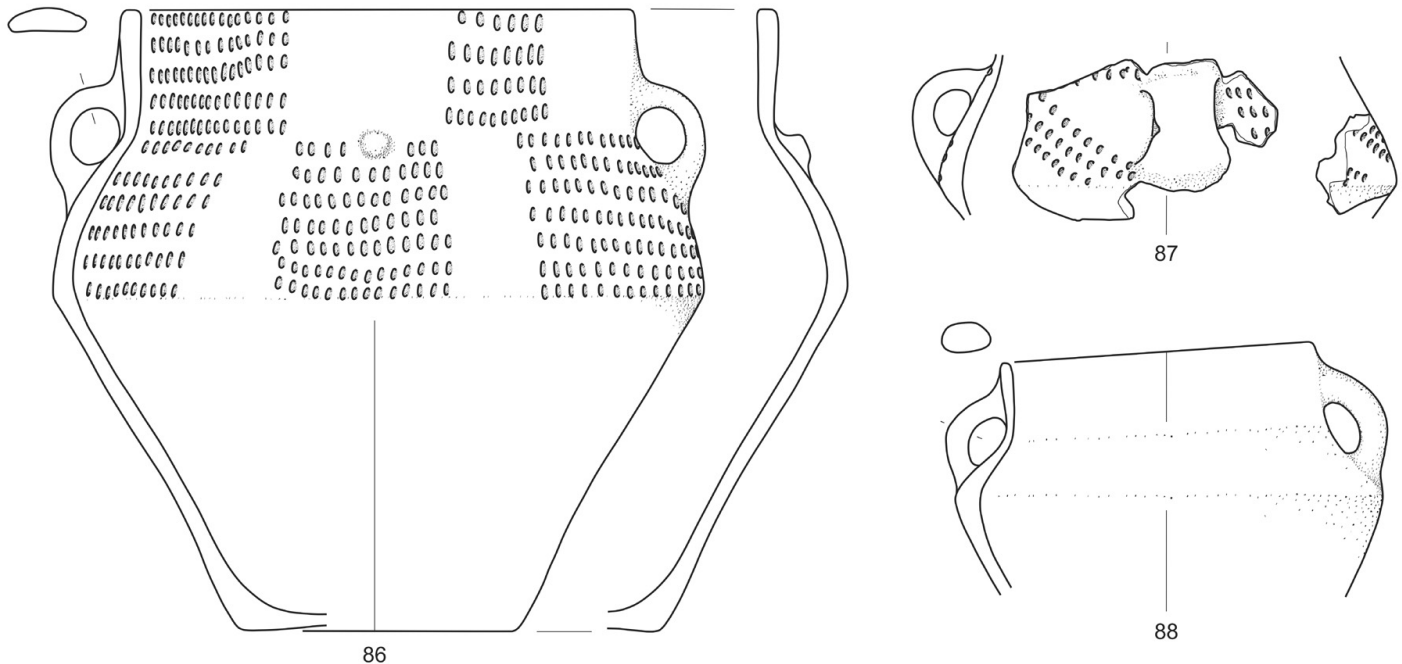

SE 410 , SE 430 and SE 435

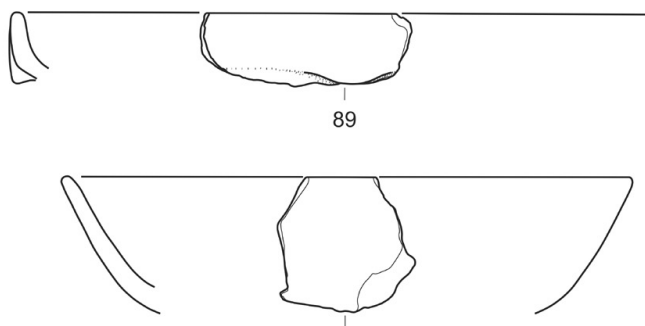

90

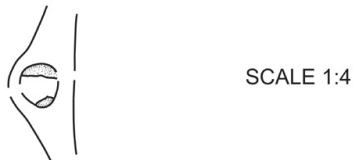

SE 430
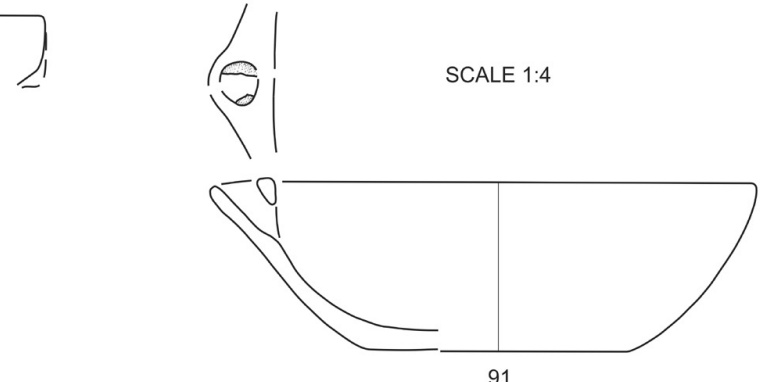

Pl. 5. Ptuj-Šolski center. Structure IV - layers $S E$ 410, 430 and 435. Pottery. 

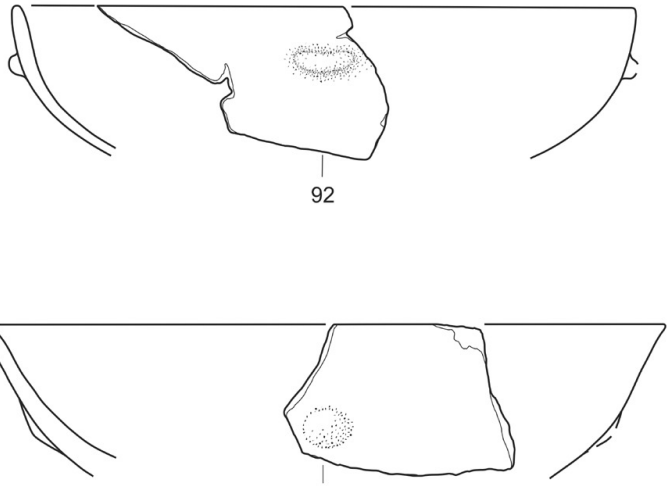

94

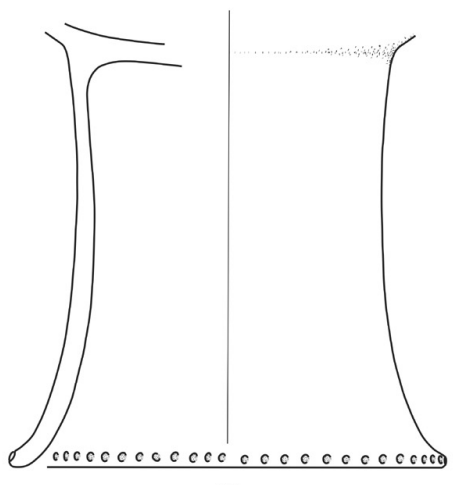

96
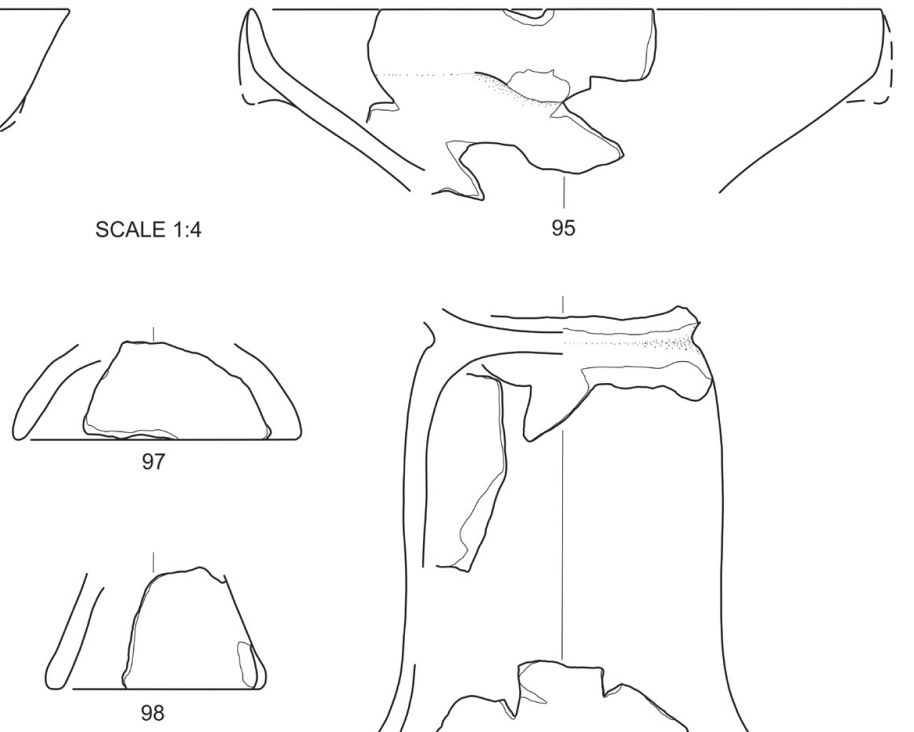

95

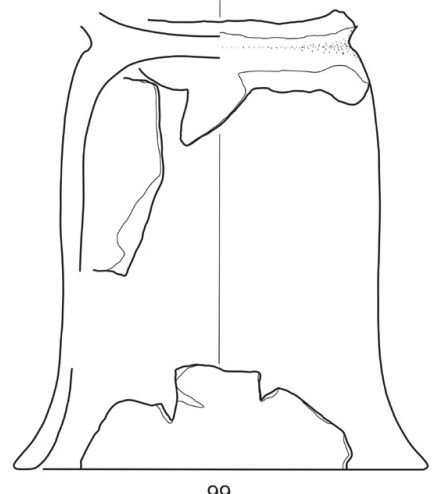

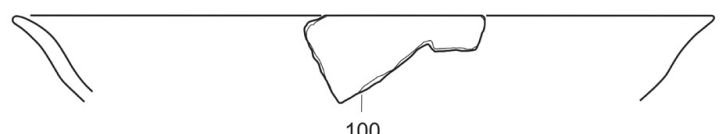

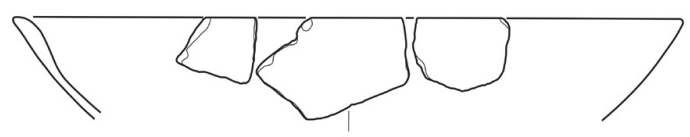

102

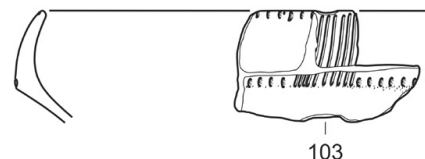

103

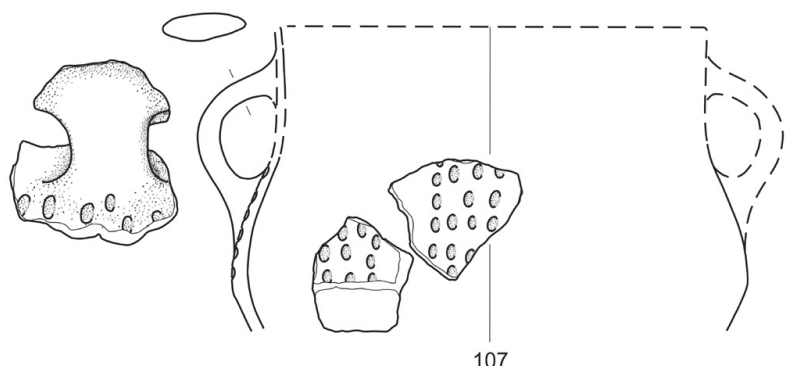

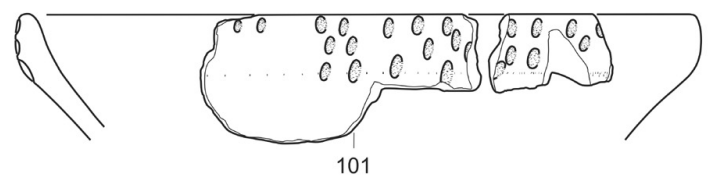

101

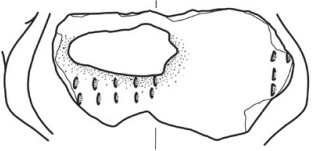

104
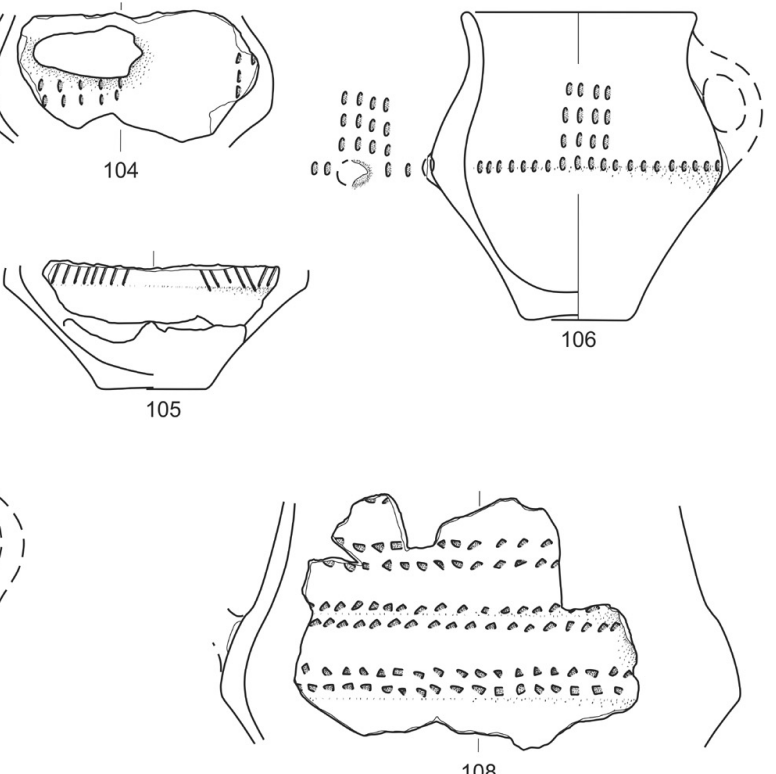

108

Pl. 6. Ptuj-Šolski center. Structure II - gray-yellowish brown layer. Pottery. 

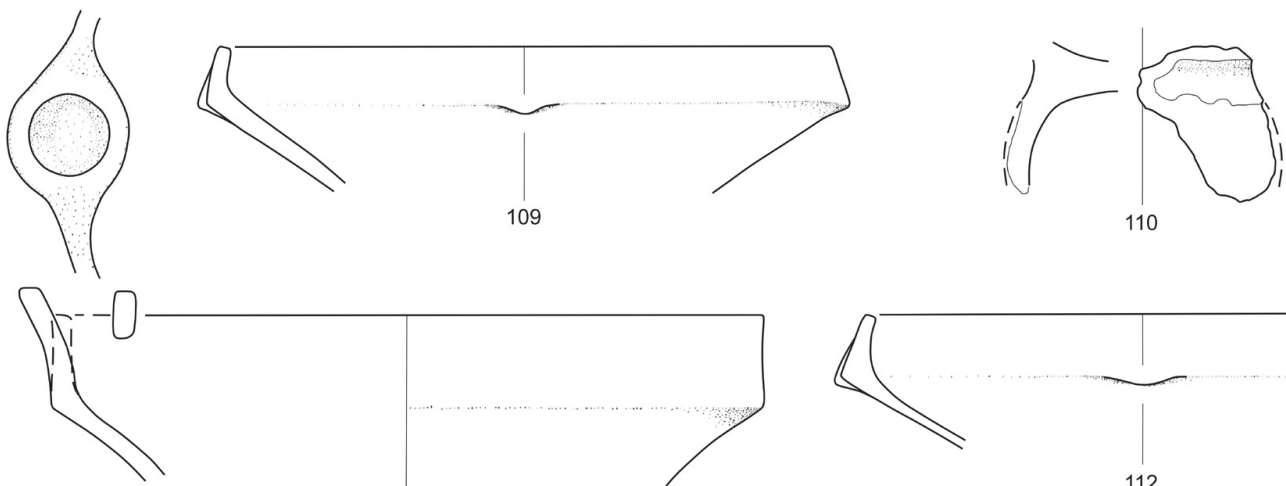

110
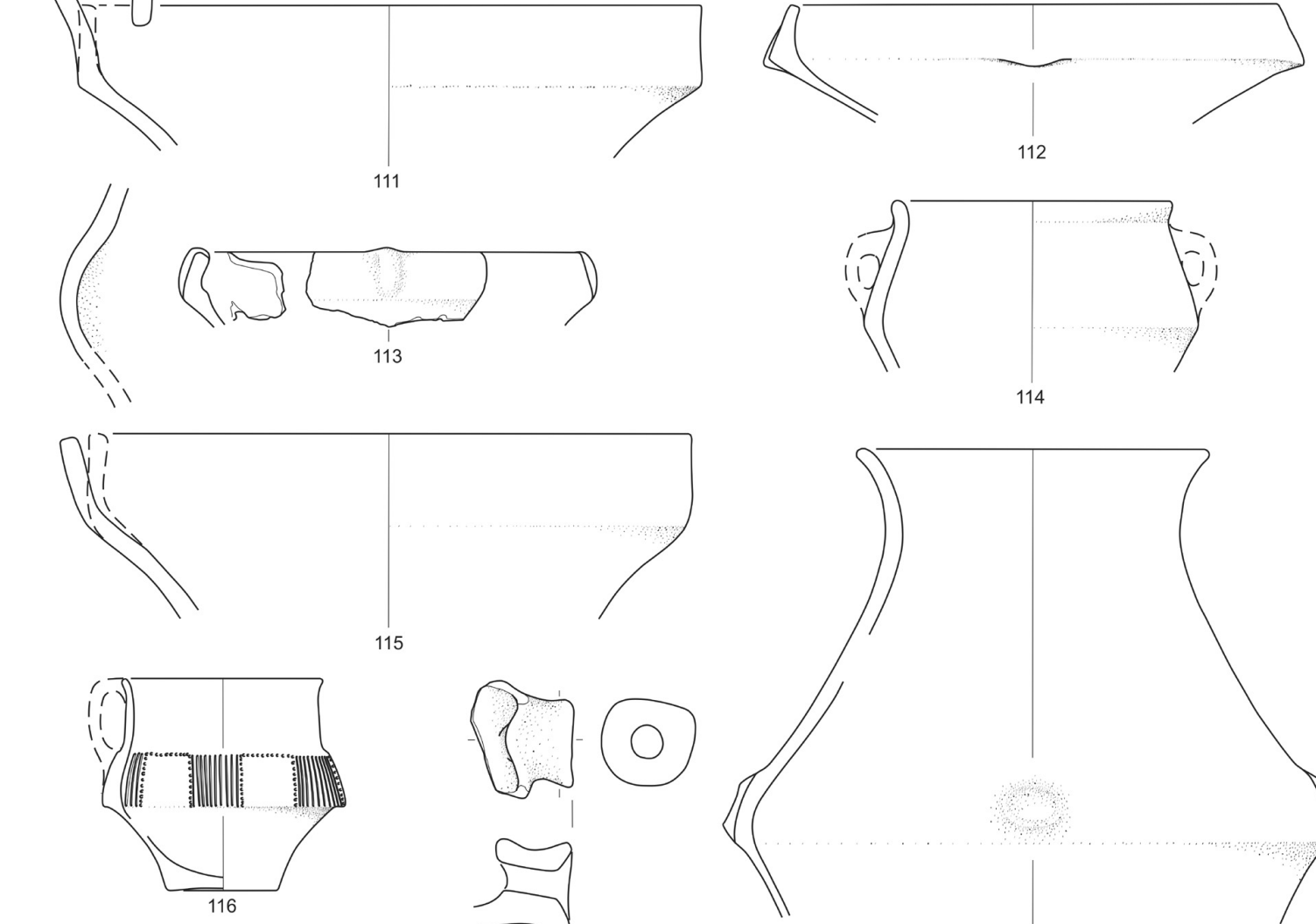

115

Structure 22 - SE 820
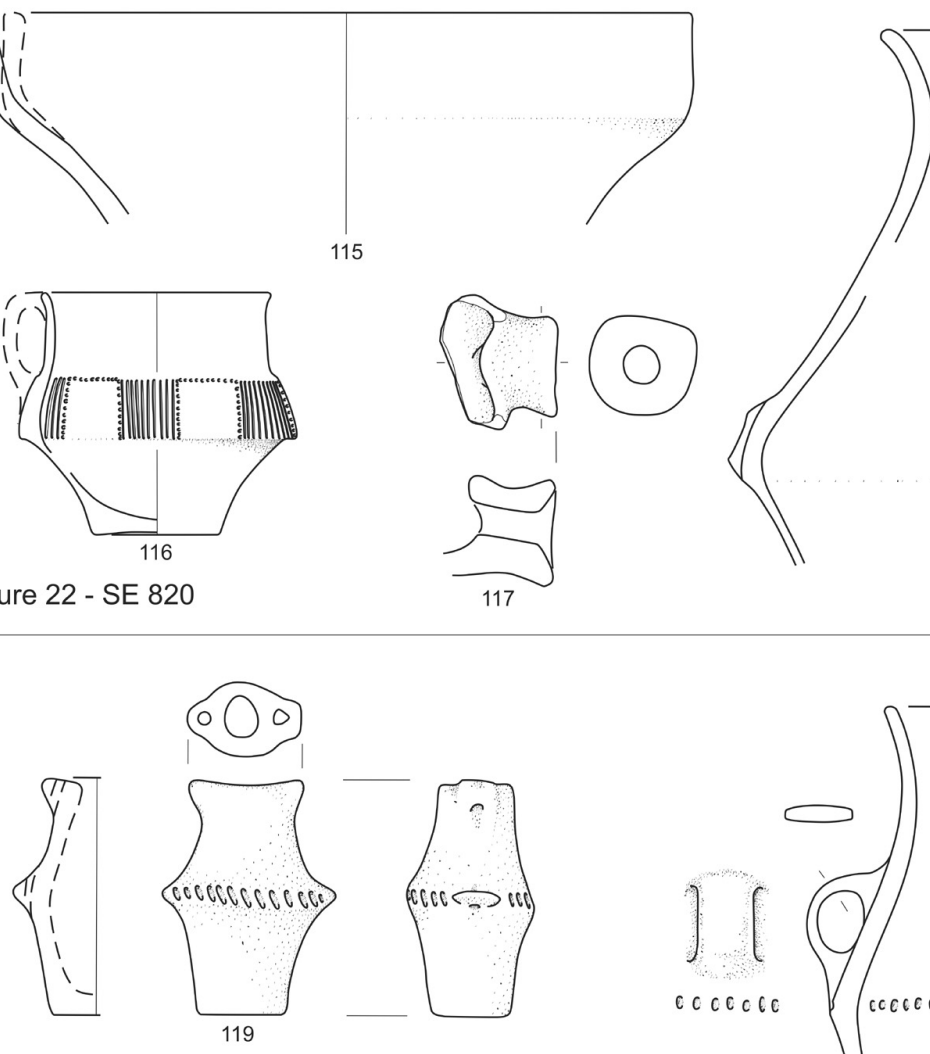

SCALE 1:4

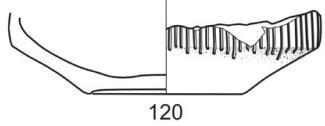

Structure 22 - SE 853
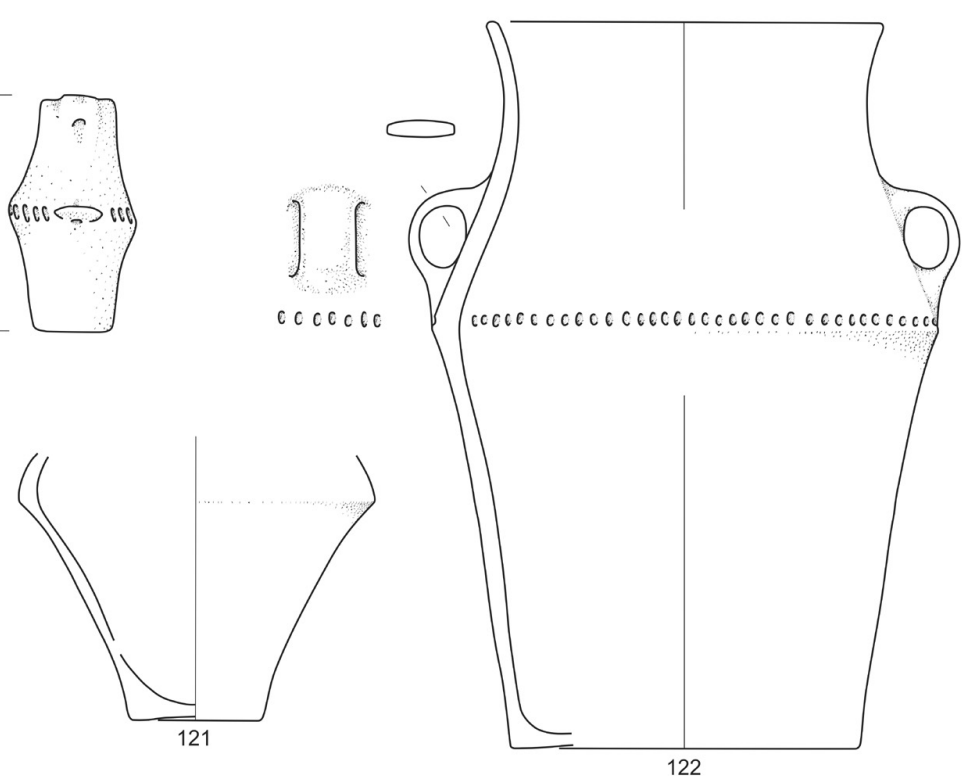

Pl. 7. Zgornje Radvanje. Structure 22 - SE 820 and SE 853. Pottery. 

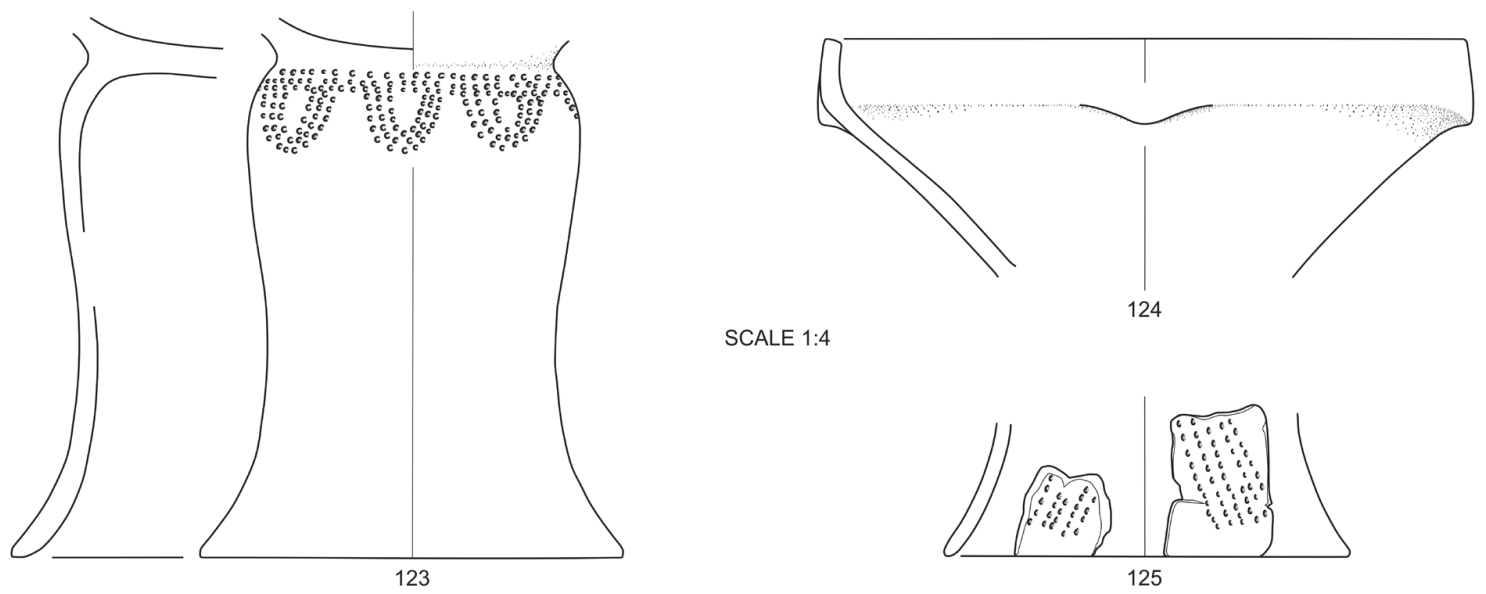

SCALE 1:4
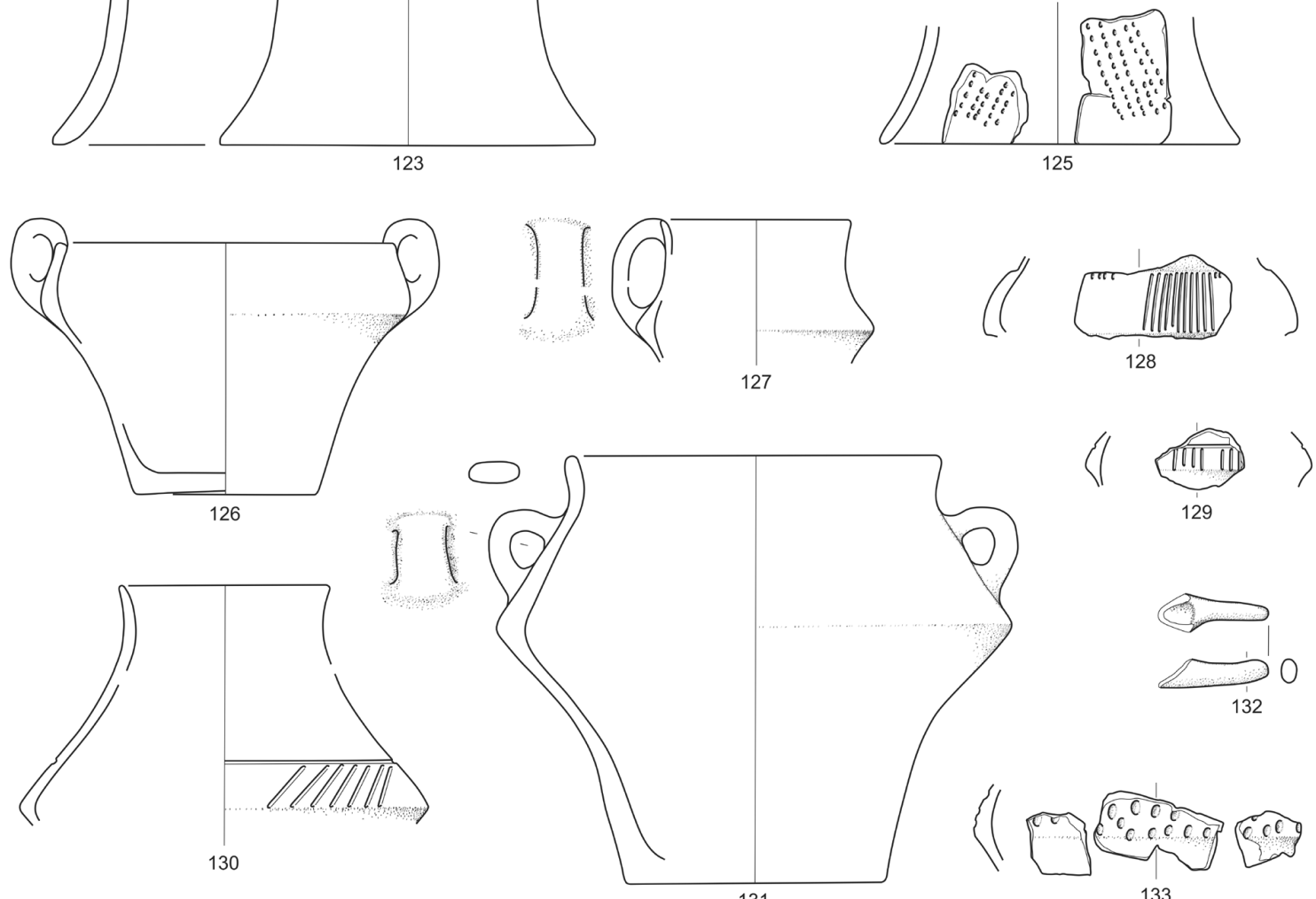

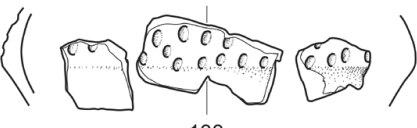

130

Structure 6 - SE $250=252=226$
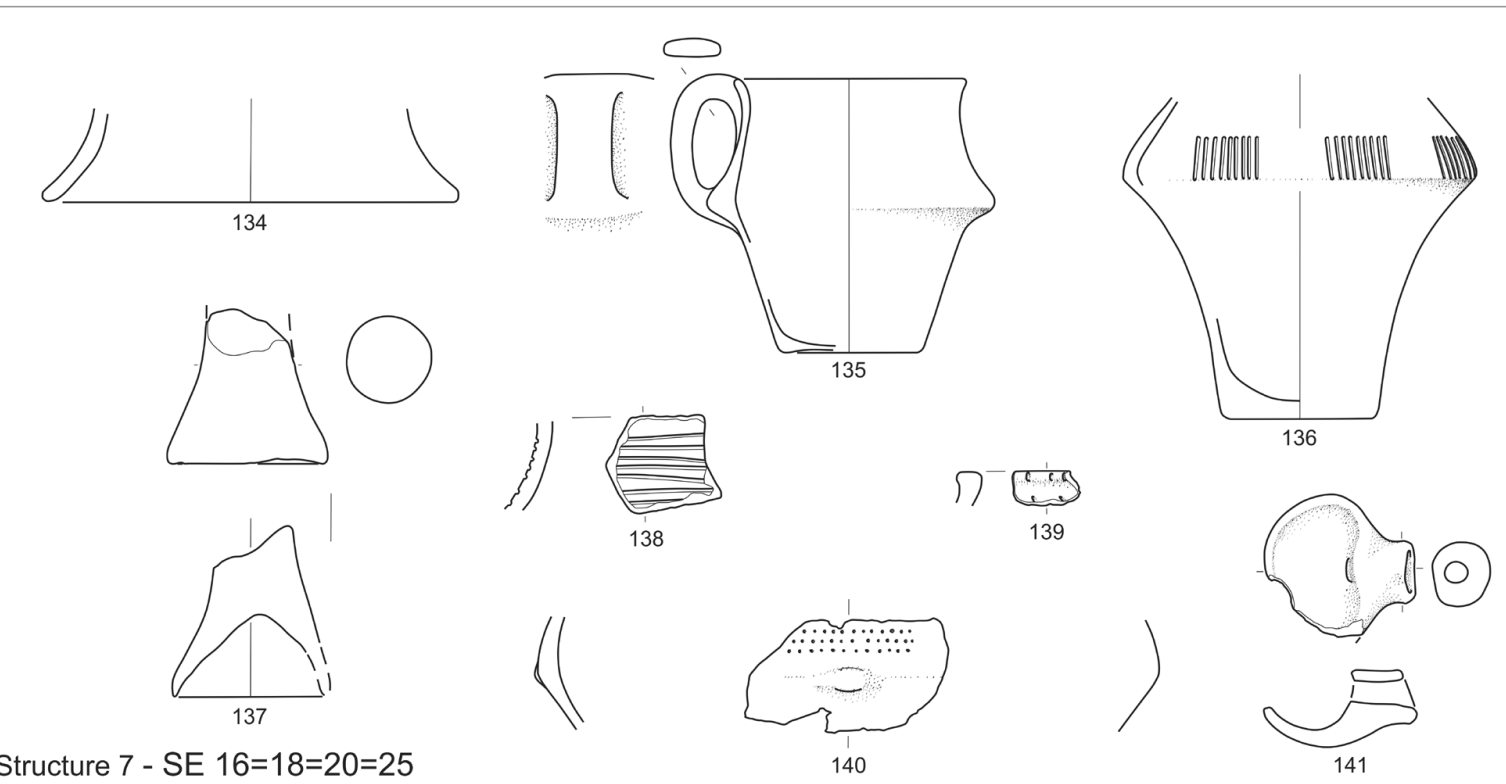

$n^{-} \underbrace{+59}_{139}$

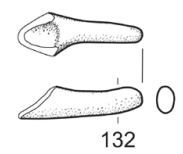

Pl. 8. Zgornje Radvanje. Structures $6(S E 250=252=226)$ and $7(S E 16=18=20=25)$. Pottery. 

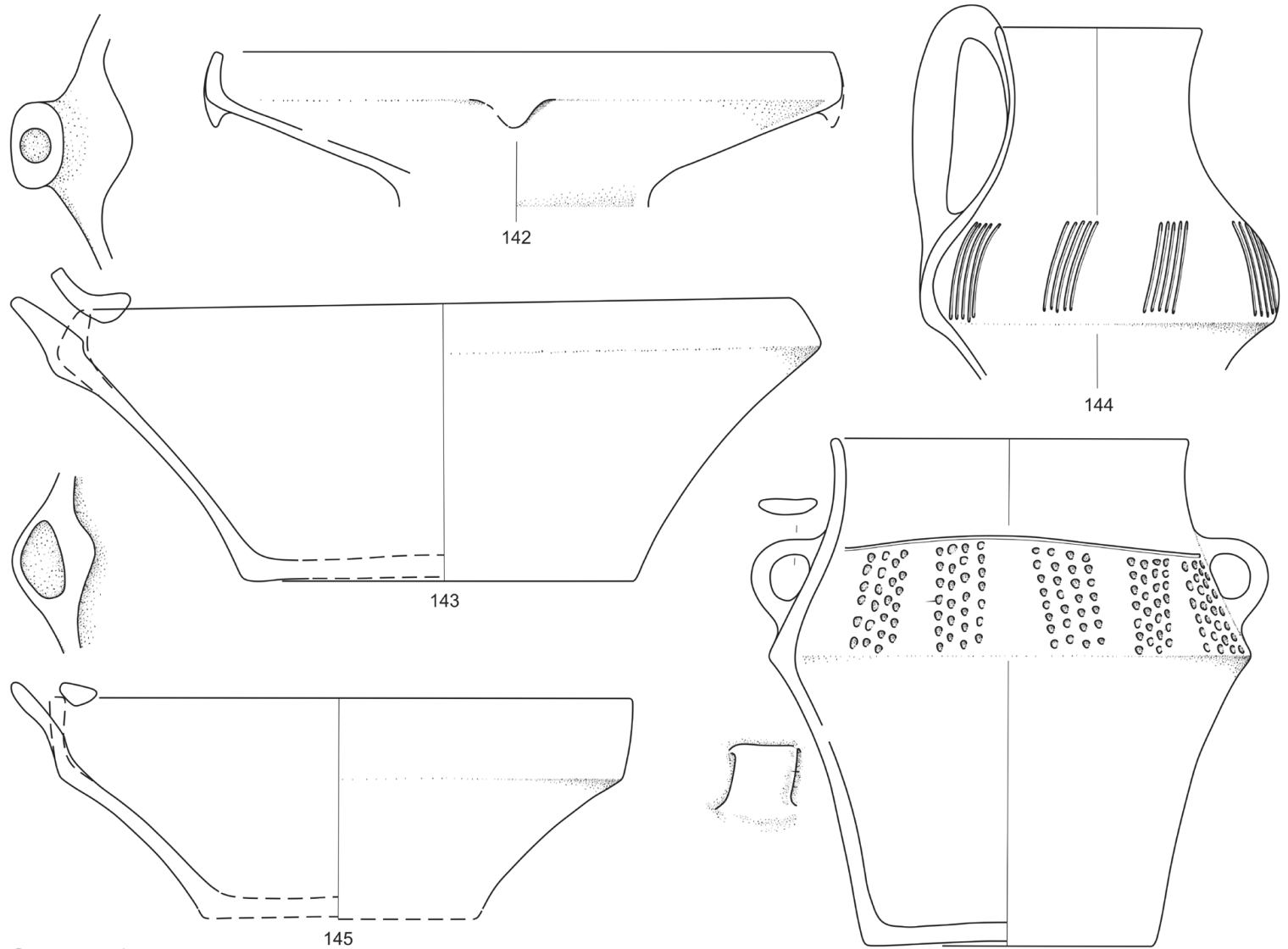

Structure 4
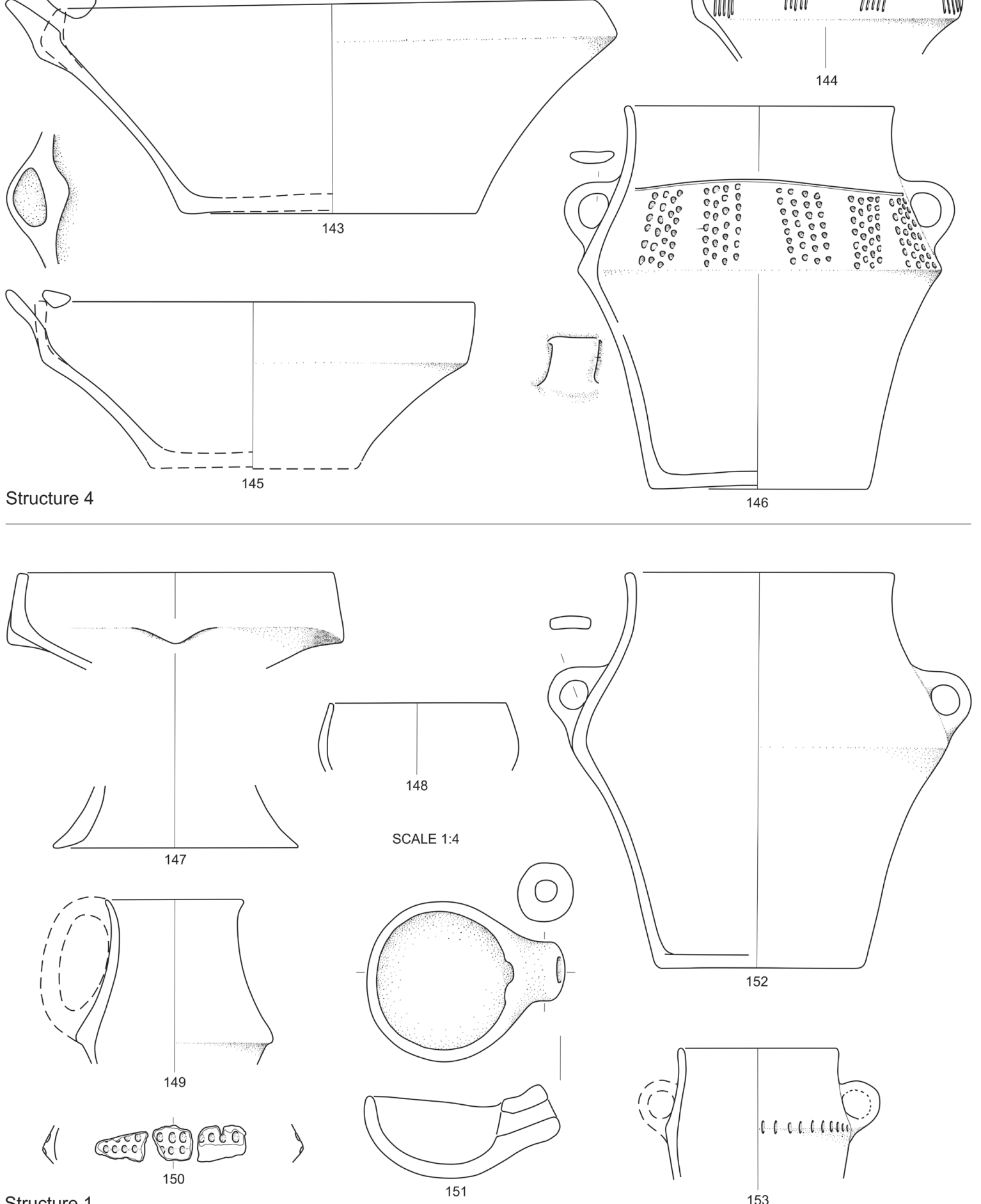

Structure 1

Pl. 9. Zgornje Radvanje. Structure 4 - SE 1128 (142-143, 145-146), SE 1102 (144). Structure 1 - SE 623 (147, 153), SE 625 (148), SE 599 (149-152). Pottery. 

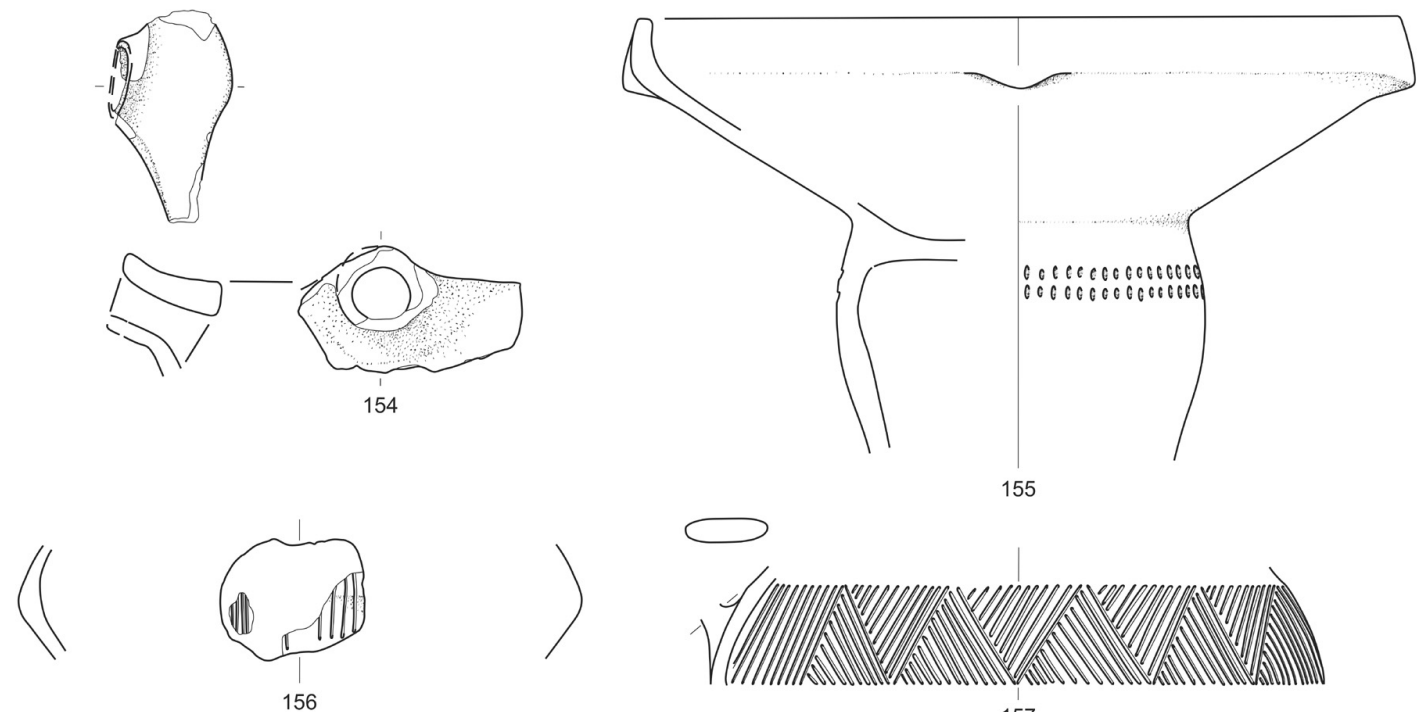

SE 1004

156

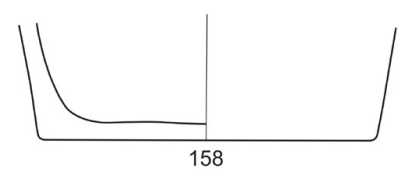

SE 1040

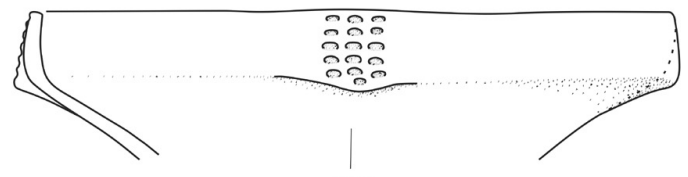

159
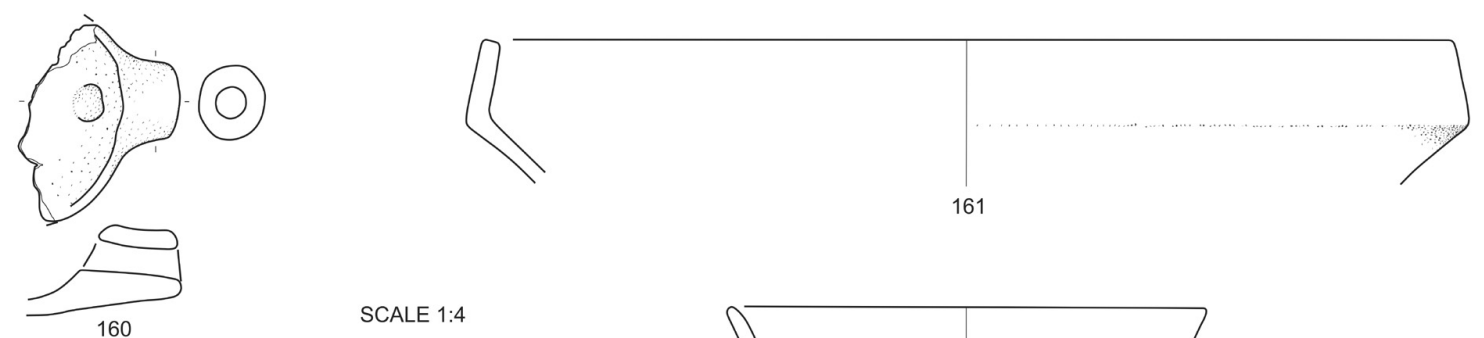

SCALE 1:4
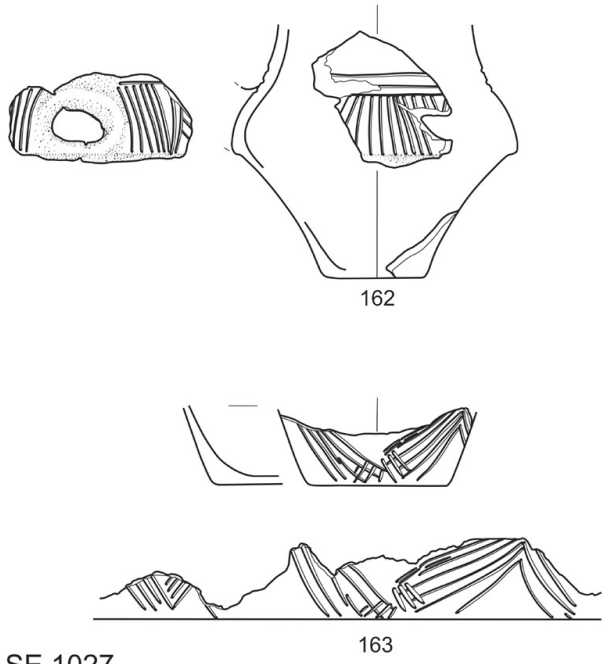

SE 1027

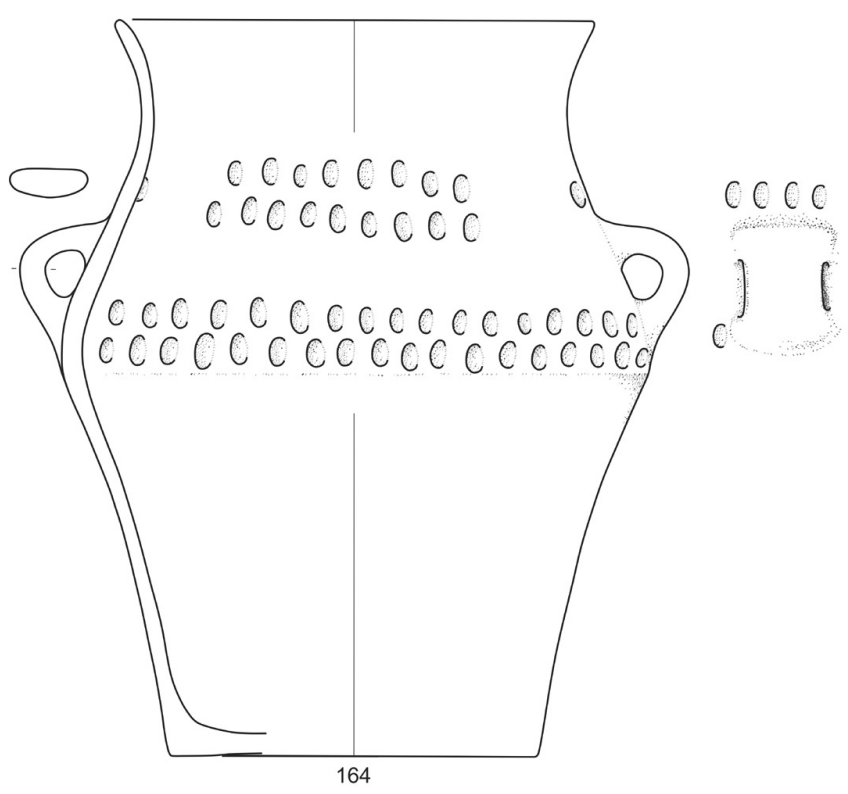

Pl. 10. Zgornje Radvanje. Structure 10 - SE 1004 (154-157), SE 1040 (158-159) and SE 1027 (160-164). Pottery. 

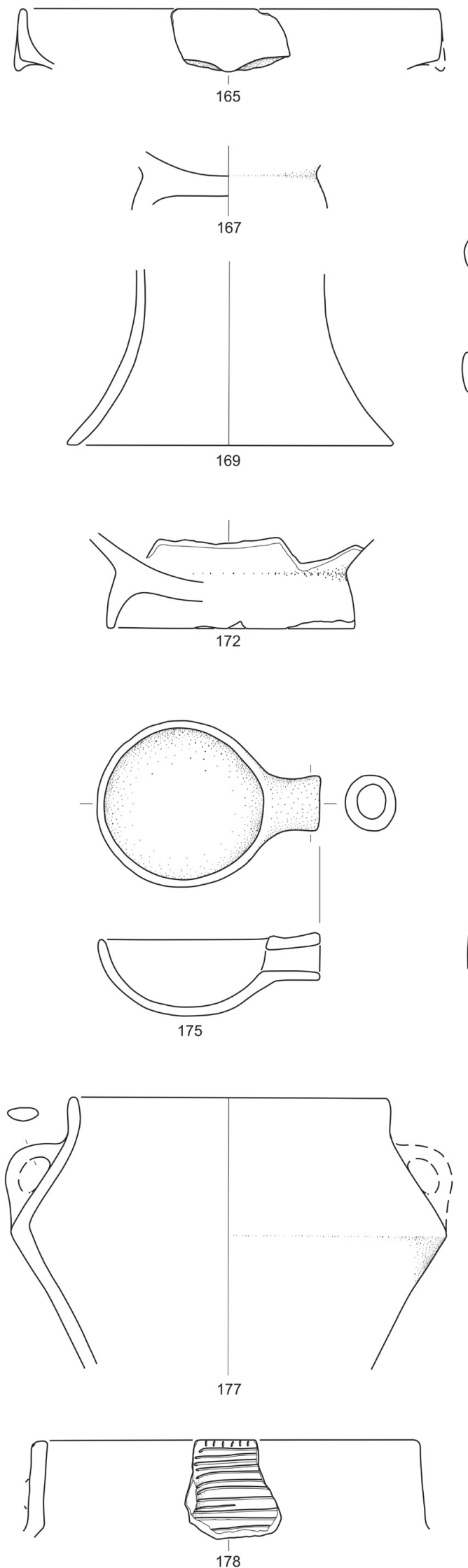
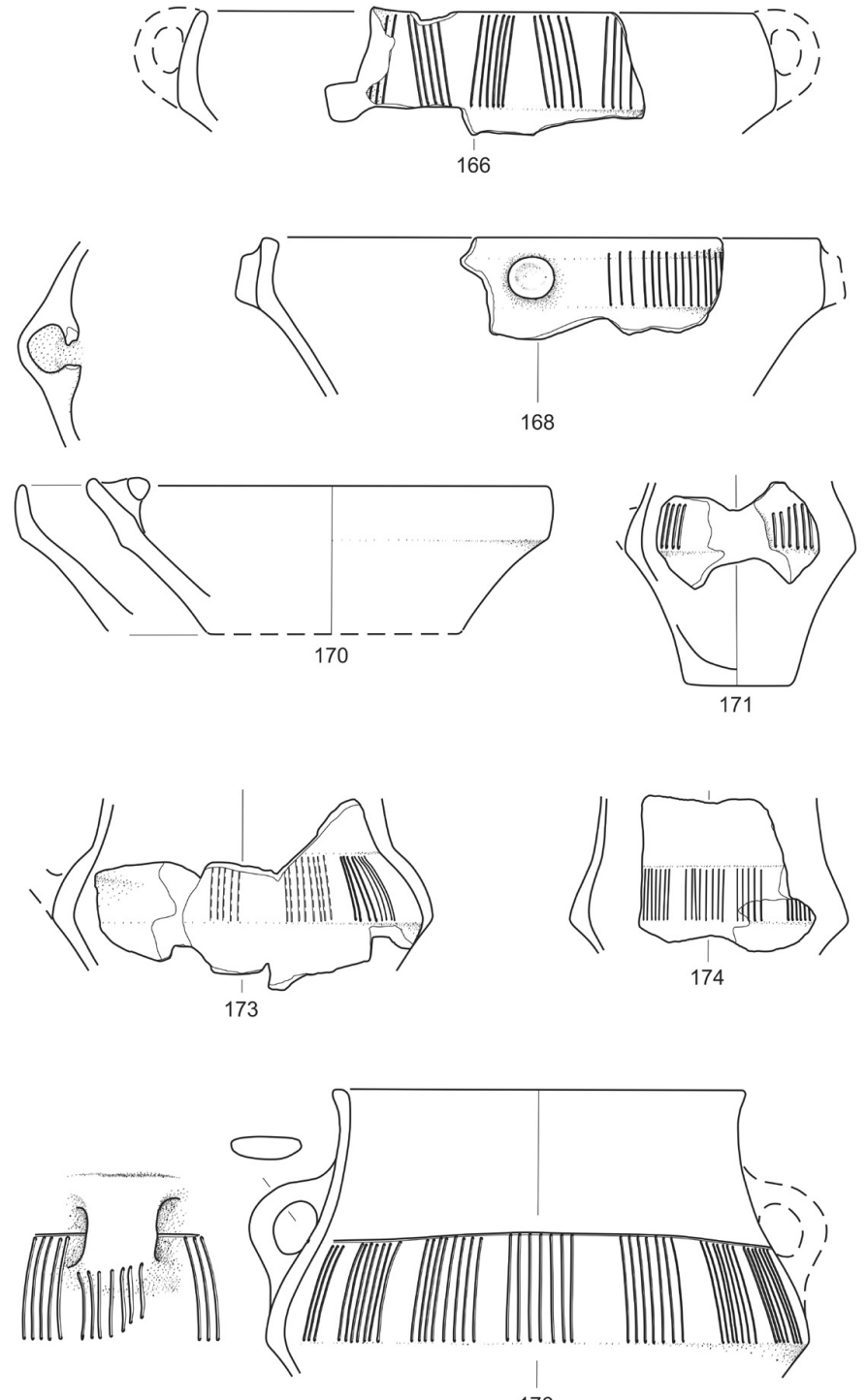

176

SCALE 1:4

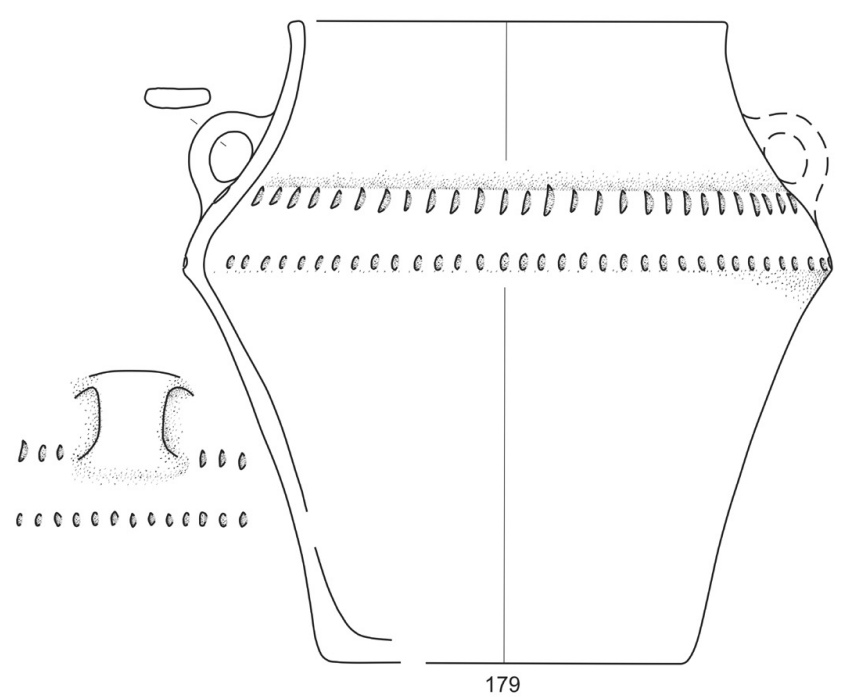

Pl. 11. Hoče-Orglarska delavnica. Pit-house I. Pottery. 

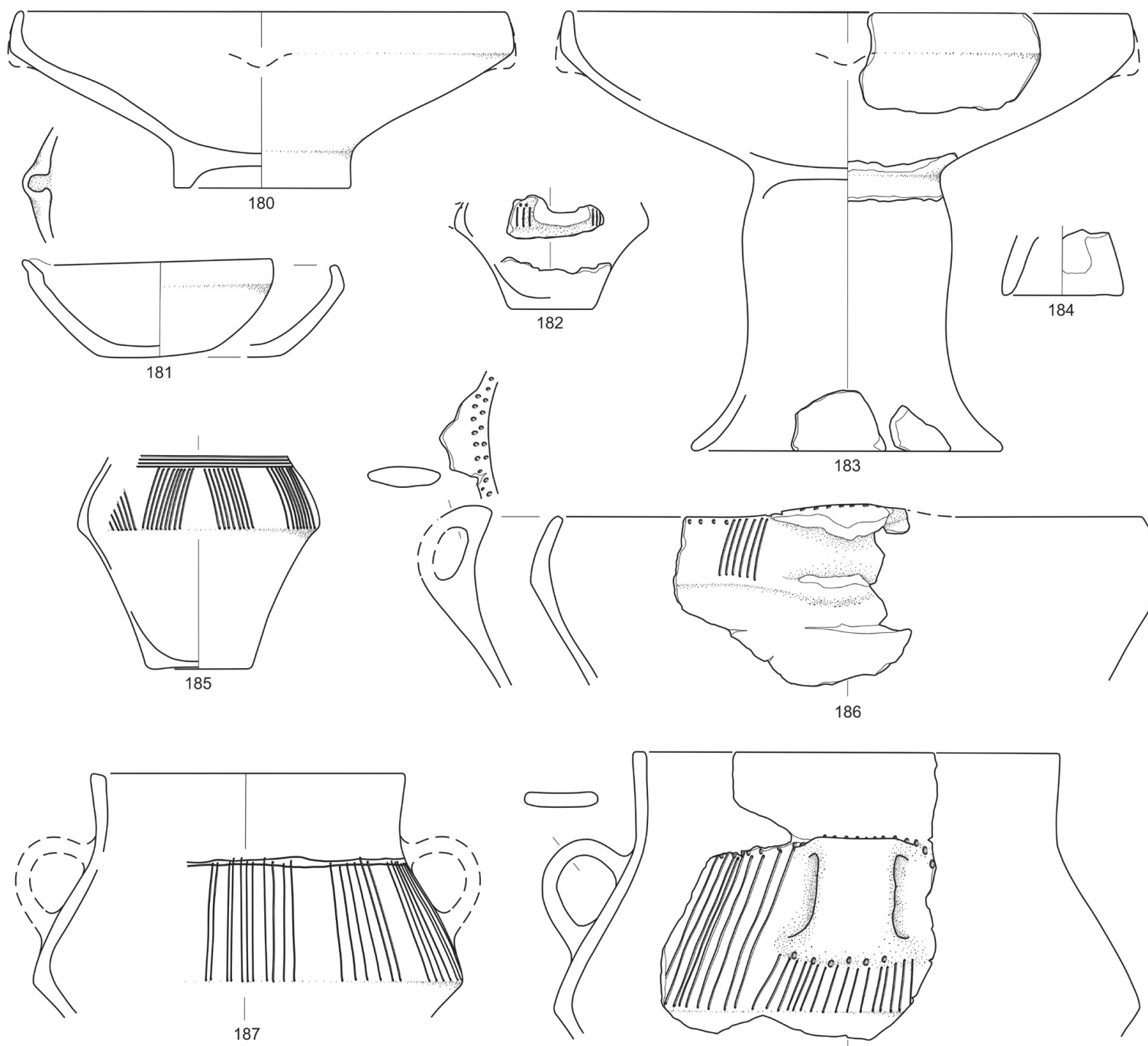

pit house 2

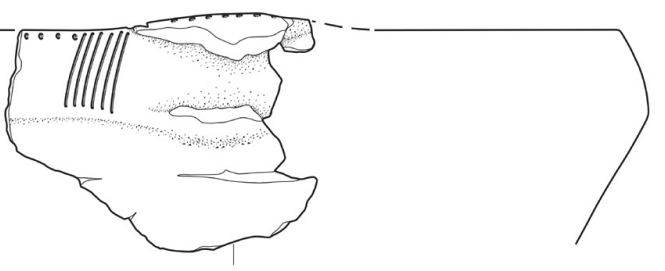

86
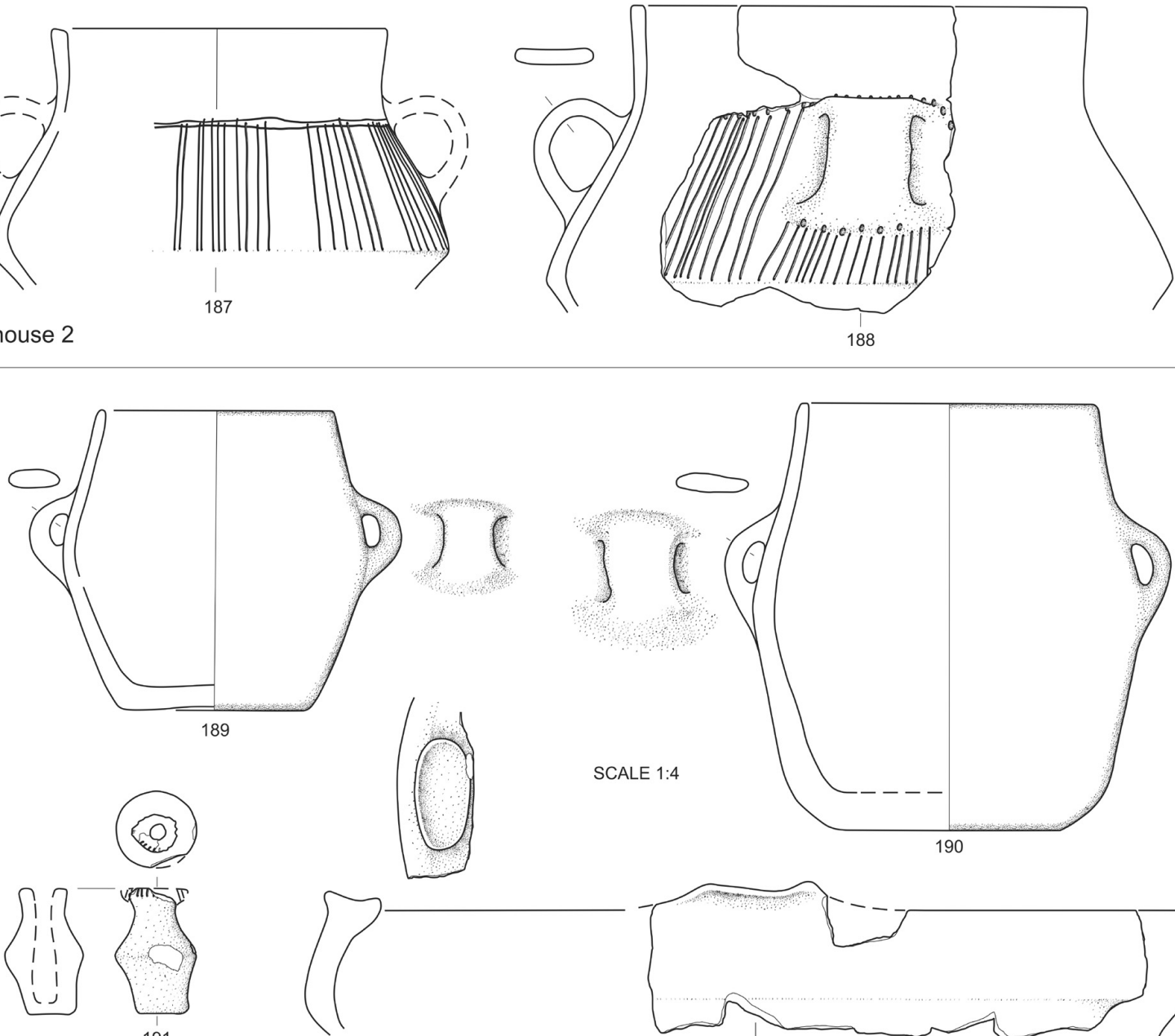

pit house 3
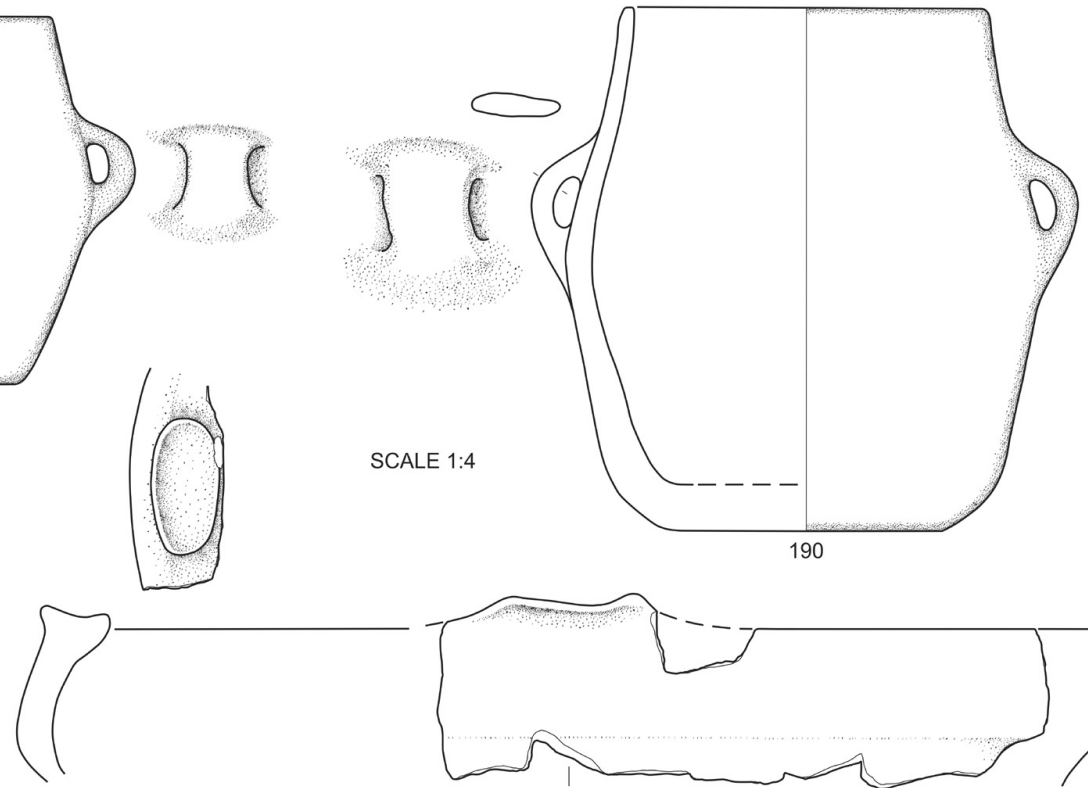

Pl. 12. Hoče-Orglarska delavnica. Pit-houses II and III. Pottery. 


\section{Appendix}

\begin{tabular}{|c|c|c|c|c|c|c|c|c|}
\hline \multirow{2}{*}{ Fabric } & \multirow{2}{*}{ Macroscopic description } & \multirow{2}{*}{ Granularity } & \multicolumn{6}{|c|}{ Quantities of different fabrics } \\
\hline & & & AN & ST1 & Šc & RAD & $\mathrm{H}$ & ST2 \\
\hline LMO1 & $\mathrm{A}_{13} ; \mathrm{C}_{21} ; \mathrm{E}_{31} ; \mathrm{E}_{21}$ & 1 & 1 & I & I & 1 & 1 & \\
\hline LMO2 & $\mathrm{A}_{13} ; \mathrm{C}_{23} ; \mathrm{E}_{31} ; \mathrm{E}_{21}$ & 1 & 1 & 3 & 133 & 628 & 54 & 23 \\
\hline LMo3 & $\mathrm{A}_{13} ; \mathrm{C}_{23} ; \mathrm{E}_{31} ; \mathrm{E}_{23}$ & 1 & 1 & I & 5 & 29 & 4 & 2 \\
\hline LMO4 & $\mathrm{A}_{21} ; \mathrm{A}_{13} ; \mathrm{C}_{21} ; \mathrm{E}_{31} ; \mathrm{E}_{21}$ & 1 & 31 & I & I & 1 & 1 & I \\
\hline LMO5 & $\mathrm{A}_{21} ; \mathrm{A} 13 ; \mathrm{C}_{23} ; \mathrm{E}_{31} ; \mathrm{E} 21$ & 1 & l & 2 & I & 39 & 5 & 6 \\
\hline LMo6 & $\mathrm{A}_{21} ; \mathrm{A}_{13} ; \mathrm{C}_{31} ; \mathrm{C}_{23} ; \mathrm{E}_{31} ; \mathrm{E}_{22}$ & 1 & 1 & I & 1 & 13 & 3 & 1 \\
\hline LMo7 & $\mathrm{A}_{21} ; \mathrm{A}_{13} ; \mathrm{C}_{32} ; \mathrm{C}_{23} ; \mathrm{E}_{31}$ & 1 & 1 & 1 & 1 & 24 & 54 & 2 \\
\hline LM०8 & $\mathrm{A}_{21} ; \mathrm{A}_{13} ; \mathrm{C}_{31} ; \mathrm{C}_{22} ; \mathrm{E}_{41} ; \mathrm{E}_{31} ; \mathrm{E}_{22}$ & 1 & l & I & 1 & 1 & 1 & 1 \\
\hline LMo9 & $\mathrm{A}_{31 ;} ; \mathrm{A}_{21} ; \mathrm{A}_{13} ; \mathrm{C}_{21} ; \mathrm{E}_{31} ; \mathrm{E} 21$ & 1 & 88 & I & I & I & 1 & I \\
\hline LM10 & $\mathrm{A}_{31} ; \mathrm{A}_{21} ; \mathrm{A}_{13} ; \mathrm{C}_{31} ; \mathrm{C}_{22} ; \mathrm{E}_{31} ; \mathrm{E}_{21}$ & 1 & 1 & 12 & 112 & 177 & 20 & 22 \\
\hline$\overline{\mathrm{LM} 11}$ & $\mathrm{~A}_{31} ; \mathrm{A}_{21} ; \mathrm{A}_{13} ; \mathrm{C}_{31} ; \mathrm{C}_{22} ; \mathrm{E}_{31} ; / 31$ & 1 & I & 1 & I & 23 & 1 & 1 \\
\hline LM12 & $\mathrm{A}_{31} ; \mathrm{A}_{21} ; \mathrm{A}_{13} ; \mathrm{C}_{31} ; \mathrm{C}_{22} ; \mathrm{E}_{32} ; \mathrm{E} 22 ; / 31$ & 1 & I & I & I & 40 & 1 & I \\
\hline LM13 & $\mathrm{A}_{31} ; \mathrm{A}_{21} ; \mathrm{A}_{13} ; \mathrm{C}_{31} ; \mathrm{C}_{22} ; \mathrm{E}_{41} ; \mathrm{E}_{32} ; \mathrm{E}_{23}$ & 1 & I & I & I & 5 & 1 & 1 \\
\hline$\overline{\mathrm{LM} 14}$ & $\mathrm{~A}_{31} ; \mathrm{A}_{21} ; \mathrm{A}_{13} ; \mathrm{C}_{32} ; \mathrm{C}_{23} ; \mathrm{E}_{31}$ & 1 & l & l & I & 6 & 16 & I \\
\hline LM15 & $\mathrm{A}_{41} ; \mathrm{A}_{31} ; \mathrm{A}_{13} ; \mathrm{C}_{31} ; \mathrm{C}_{22} ; \mathrm{E}_{31} ; \mathrm{E}_{21}$ & 1 & l & 1 & I & 6 & 2 & 7 \\
\hline$\overline{L M 16}$ & $\mathrm{~A}_{41} ; \mathrm{A}_{31} ; \mathrm{A}_{13} ; \mathrm{C}_{21} ; \mathrm{E}_{31} ; \mathrm{E}_{21}$ & 1 & 1 & I & 1 & I & 1 & 1 \\
\hline$\overline{L M 17}$ & $\mathrm{~A}_{51} ; \mathrm{A}_{31} ; \mathrm{A}_{13} ; \mathrm{C}_{31} ; \mathrm{C}_{22} ; \mathrm{E}_{31}$ & 2 & I & I & I & 1 & 1 & I \\
\hline LM18 & $\mathrm{A}_{31 ;} ; \mathrm{A}_{21} ; \mathrm{B} 13 ; \mathrm{A}_{13} ; \mathrm{C}_{21} ; \mathrm{E}_{31}$ & 2 & I & I & I & l & l & 1 \\
\hline LM19 & $\mathrm{A}_{22} ; \mathrm{A}_{13} ; \mathrm{C}_{31} ; \mathrm{C}_{22} ; \mathrm{E}_{31} ; \mathrm{E}_{21}$ & 2 & I & 7 & 132 & 55 & 6 & 1 \\
\hline$\overline{\mathrm{LM}} 2 \mathrm{O}$ & $\mathrm{A}_{22} ; \mathrm{A}_{13} ; \mathrm{C}_{31} ; \mathrm{C}_{22} ; \mathrm{D}_{31} ; \mathrm{E}_{31} ; \mathrm{E}_{21}$ & 2 & I & I & 1 & 1 & 1 & 1 \\
\hline$\overline{L M} 21$ & $\mathrm{~A}_{22} ; \mathrm{A}_{13} ; \mathrm{C}_{31} ; \mathrm{C}_{22} ; \mathrm{E}_{31} ; \mathrm{E}_{22}$ & 2 & I & I & 58 & l & I & I \\
\hline$\overline{L M 22}$ & $\mathrm{~A}_{22} ; \mathrm{A}_{13} ; \mathrm{C}_{31} ; \mathrm{C}_{22} ; \mathrm{E}_{32} ; \mathrm{E}_{22}$ & 2 & 1 & 1 & I & 4 & 1 & 1 \\
\hline$\overline{L M} 23$ & $\mathrm{~A}_{31} ; \mathrm{A}_{22}^{2} ; \mathrm{A}_{13} ; \mathrm{C}_{21} ; \mathrm{D}_{33} ; \mathrm{E}_{31}$ & 2 & 7 & I & I & l & 1 & I \\
\hline LM24 & $\mathrm{A}_{31} ; \mathrm{A}_{22} ; \mathrm{A}_{13} ; \mathrm{C}_{21} ; \mathrm{E}_{32} ; \mathrm{E}_{22}$ & 2 & 1 & l & I & l & 1 & I \\
\hline$\overline{L M} 25$ & $\mathrm{~A}_{31} ; \mathrm{A}_{22} ; \mathrm{A}_{13} ; \mathrm{C}_{22} ; \mathrm{E}_{31}$ & 2 & 10 & I & 1 & I & 1 & 1 \\
\hline$\overline{L M} 26$ & $\mathrm{~A}_{31} ; \mathrm{A}_{22} ; \mathrm{A}_{13} ; \mathrm{C}_{31} ; \mathrm{C}_{22} ; \mathrm{E}_{31}$ & 2 & 1 & 1 & 43 & 50 & 7 & 5 \\
\hline LM27 & $\mathrm{A}_{31} ; \mathrm{A}_{22} ; \mathrm{A}_{13} ; \mathrm{C}_{31} ; \mathrm{C}_{22} ; \mathrm{E}_{3} ; \mathrm{E}_{21} ; 3_{31}$ & 2 & I & l & I & 36 & 1 & 1 \\
\hline$\overline{\mathrm{LM}} 28$ & $\mathrm{~A}_{31} ; \mathrm{A}_{22} ; \mathrm{A}_{13} ; \mathrm{C}_{31} ; \mathrm{C}_{22} ; \mathrm{E}_{31} ; \mathrm{E}_{22} ; / 31 ; / 23$ & 2 & I & I & 1 & 6 & 1 & 1 \\
\hline$\overline{L M} 29$ & $\mathrm{~A}_{31} ; \mathrm{A} 22 ; \mathrm{A}_{13} ; \mathrm{C}_{31} ; \mathrm{C}_{22} ; \mathrm{E}_{22} ; \mathrm{E}_{22}$ & 2 & 1 & 11 & 1 & I & 1 & 1 \\
\hline $\mathrm{LM}_{3} \mathrm{O}$ & $\mathrm{A}_{31} ; \mathrm{A}_{22} ; \mathrm{A}_{13} ; \mathrm{C}_{31} ; \mathrm{C}_{22} ; \mathrm{E}_{22} ; \mathrm{E}_{22} ; / 31$ & 2 & l & 5 & I & 29 & 1 & I \\
\hline $\mathrm{LM}_{31}$ & $\mathrm{~A}_{31} ; \mathrm{A}_{22} ; \mathrm{A}_{13} ; \mathrm{C}_{32} ; \mathrm{C}_{23} ; \mathrm{E}_{31}$ & 2 & I & 1 & 1 & 71 & 19 & 1 \\
\hline$\overline{\mathrm{LM}_{32}}$ & $\mathrm{~A}_{31} ; \mathrm{A}_{22} ; \mathrm{A}_{13} ; \mathrm{C}_{22} ; \mathrm{C}_{23} ; \mathrm{E}_{31} ; / 31$ & 2 & 1 & I & 1 & 6 & 1 & 1 \\
\hline $\mathrm{LM}_{33}$ & $\mathrm{~A}_{23} ; \mathrm{A}_{13} ; \mathrm{C}_{22} ; \mathrm{E}_{41} ; \mathrm{E}_{31} ; \mathrm{E}_{22}$ & 2 & l & l & 1 & 2 & I & I \\
\hline $\mathrm{LM}_{34}$ & $\mathrm{~A}_{23} ; \mathrm{A}_{13} ; \mathrm{C}_{31} ; \mathrm{C}_{22} ; \mathrm{E}_{31} ; \mathrm{E}_{21}$ & 2 & I & 1 & I & 17 & 8 & 1 \\
\hline $\mathrm{LM}_{35}$ & $\mathrm{~A}_{23} ; \mathrm{A}_{13} ; \mathrm{C}_{32} ; \mathrm{C}_{23} ; \mathrm{E}_{31} ; \mathrm{E}_{21}$ & 2 & I & 1 & 1 & 4 & 5 & 1 \\
\hline $\mathrm{LM}_{36} 6$ & $\mathrm{~A}_{23} ; \mathrm{A}_{13} ; \mathrm{C}_{31} ; \mathrm{C}_{22} ; \mathrm{E}_{32} ; \mathrm{E}_{21}$ & 2 & l & I & 48 & l & 1 & I \\
\hline $\mathrm{LM}_{37}$ & $\mathrm{~A}_{23} ; \mathrm{A}_{13} ; \mathrm{C}_{31} ; \mathrm{C}_{22} ; \mathrm{E}_{32} ; \mathrm{E}_{23} ; / 21$ & 2 & I & I & I & 3 & l & 1 \\
\hline $\mathrm{LM}_{3} 8$ & $\mathrm{~A}_{23} ; \mathrm{A}_{13} ; \mathrm{C}_{22} ; \mathrm{C}_{23} ; \mathrm{E}_{31} ; \mathrm{E} 21$ & 2 & 1 & 1 & 1 & 12 & 1 & 1 \\
\hline $\mathrm{LM}_{39}$ & $\mathrm{~A}_{31} ; \mathrm{A}_{23} ; \mathrm{A}_{13} ; \mathrm{C}_{22} ; \mathrm{E}_{31} ; \mathrm{E} 22 ; \mid 21$ & 2 & I & I & I & 19 & 1 & 1 \\
\hline $\mathrm{LM} 4 \mathrm{O}$ & 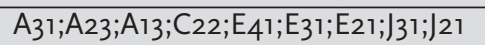 & 2 & I & I & I & 15 & 1 & 1 \\
\hline$\overline{\mathrm{LM}} 41$ & $\mathrm{~A}_{31} ; \mathrm{A}_{23} ; \mathrm{A}_{13} ; \mathrm{C}_{31} ; \mathrm{C}_{22} ; \mathrm{E}_{21}$ & 2 & I & I & 1 & 40 & 1 & 1 \\
\hline $\mathrm{LM}_{42}$ & $\mathrm{~A}_{31} ; \mathrm{A}_{23} ; \mathrm{A}_{13} ; \mathrm{C}_{32} ; \mathrm{C}_{22} ; \mathrm{E}_{31} ; \mathrm{E}_{22} ; 21$ & 2 & I & I & I & 1 & 1 & 1 \\
\hline LM43 & $\mathrm{A}_{31} ; \mathrm{A}_{23} ; \mathrm{C}_{31} ; \mathrm{C}_{22,} \mathrm{D}_{31} ; \mathrm{E}_{41} ; \mathrm{E}_{31} ; \mathrm{E}_{23}$ & 2 & 1 & l & I & 1 & 1 & 1 \\
\hline LM44 & $\mathrm{A}_{32} ; \mathrm{A}_{21} ; \mathrm{A}_{13} ; \mathrm{C}_{31} ; \mathrm{C}_{22} ; \mathrm{E}_{21}$ & 3 & l & l & I & 26 & I & I \\
\hline LM45 & $\mathrm{A}_{32} ; \mathrm{A}_{21} ; \mathrm{A}_{13} ; \mathrm{C}_{31} ; \mathrm{C}_{22} ; \mathrm{E}_{31} ; / 31 ; \mid 21$ & 3 & I & I & I & 15 & 1 & I \\
\hline LM46 & $\mathrm{A}_{32} ; \mathrm{A}_{21} ; \mathrm{A}_{13} ; \mathrm{C}_{32} ; \mathrm{C}_{22} ; \mathrm{E}_{21}$ & 3 & 1 & l & 1 & 11 & 1 & 1 \\
\hline$\overline{L M} 47$ & $\mathrm{~A}_{32} ; \mathrm{A}_{22} ; \mathrm{A}_{13} ; \mathrm{C}_{21} ; \mathrm{E}_{31}$ & 3 & 7 & I & 1 & 1 & 1 & 1 \\
\hline LM48 & $\mathrm{A}_{32} ; \mathrm{A}_{22} ; \mathrm{A}_{13} ; \mathrm{C}_{31} ; \mathrm{C}_{22} ; \mathrm{E}_{31}$ & 3 & 1 & I & 1 & 61 & 3 & 12 \\
\hline LM49 & $\mathrm{A}_{32} ; \mathrm{A}_{22} ; \mathrm{A}_{13} ; \mathrm{C}_{31} ; \mathrm{C}_{22} ; \mathrm{E}_{31} ; / 31$ & 3 & l & l & I & 6 & 1 & I \\
\hline LM50 & $\mathrm{A}_{32} ; \mathrm{A}_{22} ; \mathrm{A} 13 ; \mathrm{C}_{31} ; \mathrm{C}_{22} ; \mathrm{E}_{32} ; \mathrm{E} 21 ; / 31$ & 3 & I & 1 & I & 44 & & I \\
\hline LM51 & $\mathrm{A}_{32} ; \mathrm{A}_{22} ; \mathrm{A}_{13} ; \mathrm{C}_{31} ; \mathrm{C}_{22} ; \mathrm{E}_{33}$ & 3 & l & I & I & 1 & 1 & 4 \\
\hline
\end{tabular}




\begin{tabular}{|c|c|c|c|c|c|c|c|c|}
\hline \multirow{2}{*}{ Fabric } & \multirow{2}{*}{ Macroscopic description } & \multirow{2}{*}{ Granularity } & \multicolumn{6}{|c|}{ Quantities of different fabrics } \\
\hline & & & AN & ST1 & ŠC & RAD & $\mathrm{H}$ & $\mathrm{ST}_{2}$ \\
\hline$\overline{\mathrm{LM}_{52}}$ & $\mathrm{~A}_{32} ; \mathrm{A}_{22} ; \mathrm{A}_{13} ; \mathrm{C}_{32} ; \mathrm{C}_{23} ; \mathrm{E}_{31}$ & 3 & l & l & l & 27 & 4 & I \\
\hline LM53 & $\mathrm{A}_{32} ; \mathrm{A}_{23} ; \mathrm{C}_{22} ; \mathrm{E}_{32} ; \mathrm{E} 21$ & 3 & 1 & 1 & 10 & 17 & 1 & 1 \\
\hline LM54 & $\mathrm{A}_{32} ; \mathrm{A}_{23} ; \mathrm{C}_{41} ; \mathrm{C}_{31} ; \mathrm{C}_{22} ; \mathrm{E}_{32} ; \mathrm{E}_{21}$ & 3 & l & l & l & 2 & l & 1 \\
\hline LM55 & $\mathrm{A}_{32} ; \mathrm{A}_{23} ; \mathrm{C}_{22} ; \mathrm{E}_{22} ; \mathrm{E} 21 ; / 31 ; ; 22$ & 3 & l & l & I & 2 & 1 & 3 \\
\hline LM56 & $\mathrm{A}_{33} ; \mathrm{A}_{22} ; \mathrm{C}_{31} ; \mathrm{C}_{22} ; \mathrm{E}_{31}$ & 3 & 1 & l & 1 & 6 & 1 & 1 \\
\hline LM57 & $\mathrm{A}_{33} ; \mathrm{A}_{23} ; \mathrm{C}_{22} ; \mathrm{E}_{31}$ & 3 & I & I & I & 3 & 1 & I \\
\hline LM58 & 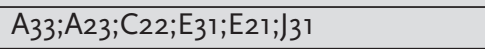 & 3 & l & l & I & 12 & I & I \\
\hline LM59 & $\mathrm{A}_{41} ; \mathrm{A}_{32} ; \mathrm{A}_{22} ; \mathrm{A}_{13} ; \mathrm{C}_{31} ; \mathrm{C}_{22} ; \mathrm{D}_{31} ; \mathrm{E}_{32}$ & 3 & l & l & l & 5 & I & I \\
\hline LM6o & $\mathrm{A}_{42} ; \mathrm{A}_{31} ; \mathrm{A}_{21} ; \mathrm{A}_{13} ; \mathrm{C}_{31} ; \mathrm{C}_{22} ; \mathrm{E}_{31} ; \mathrm{E}_{21} ; / 31$ & 4 & l & l & l & 15 & I & 1 \\
\hline LM61 & $\mathrm{A}_{42} ; \mathrm{A}_{31} ; \mathrm{A}_{21} ; \mathrm{A}_{13} ; \mathrm{C}_{22} ; \mathrm{E}_{31}$ & 4 & l & l & l & l & I & 2 \\
\hline LM62 & $\mathrm{A}_{42} ; \mathrm{A}_{31} ; \mathrm{A}_{21} ; \mathrm{A}_{13} ; \mathrm{C}_{32} ; \mathrm{C}_{22} ; \mathrm{E}_{31}$ & 4 & I & I & l & I & l & 2 \\
\hline
\end{tabular}

App. 1. Pottery fabrics and their representation in the Late Neolithic pottery assemblages at Andrenci (AN) and Stoperce 1 (ST1) and Early Eneolithic pottery assemblages at Ptuj-Šolski center (ŠC), Zgornje Radvanje (RAD), Hoče-Orglarska delavnica (H) and Stoperce (ST2). Fabric codes, firstly define type of a particular grain (A - quartz, B - calcium carbonate, $C$ - mica, D-charred organic substance, $E$ - iron oxides, J - undefined white grains), followed by its size $(1-<0.25 \mathrm{~mm}, 2-0.26$ to $0.50 \mathrm{~mm}, 3-0.51$ to $2.0 \mathrm{~mm}, 4-2.01$ to $3 \mathrm{~mm}$ and 5 - >3mm), and finally their frequency (1 - <5 grains per $\mathrm{mm}^{2}, 2-5$ to 10 grains per $\mathrm{mm}^{2}$ and 3 - >10 particles per $\mathrm{mm}^{2}$ ). 


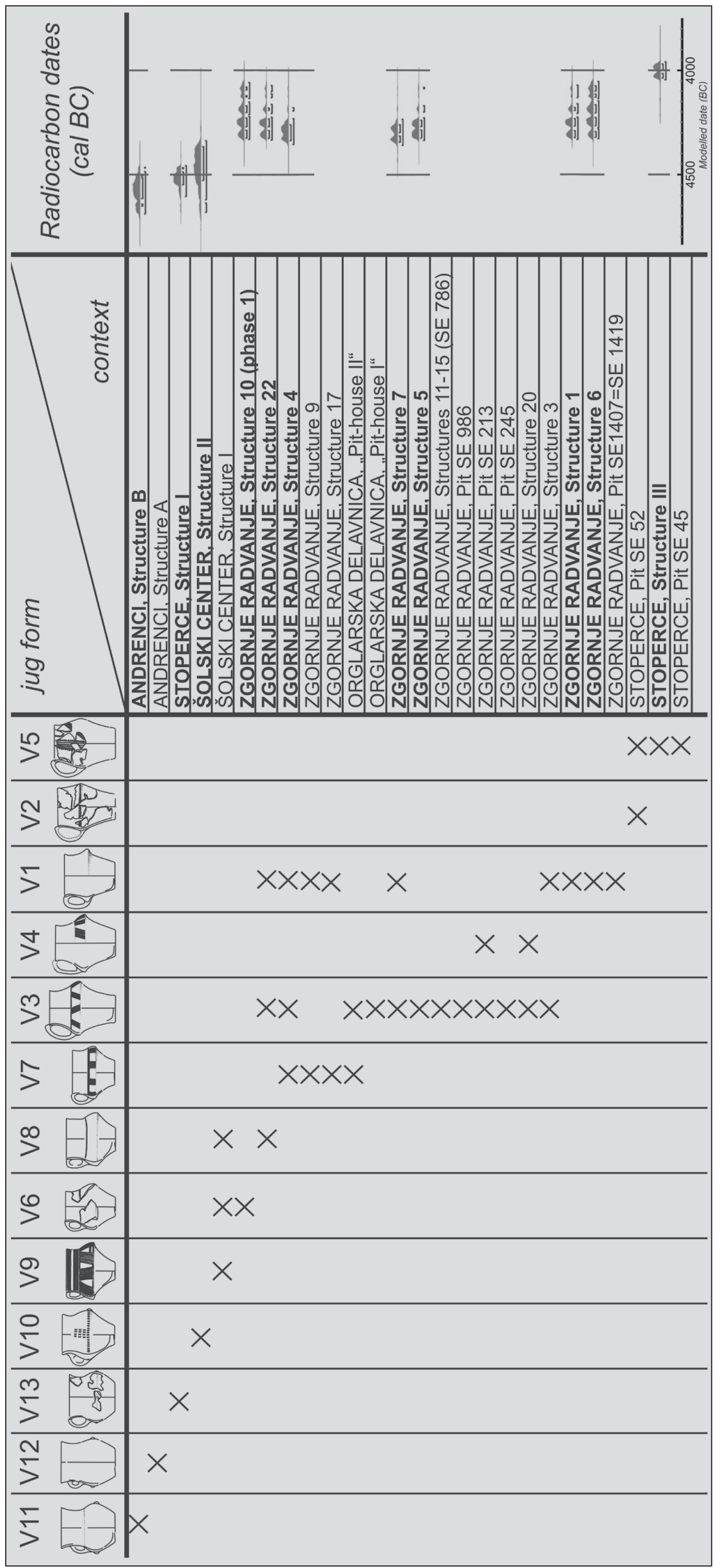




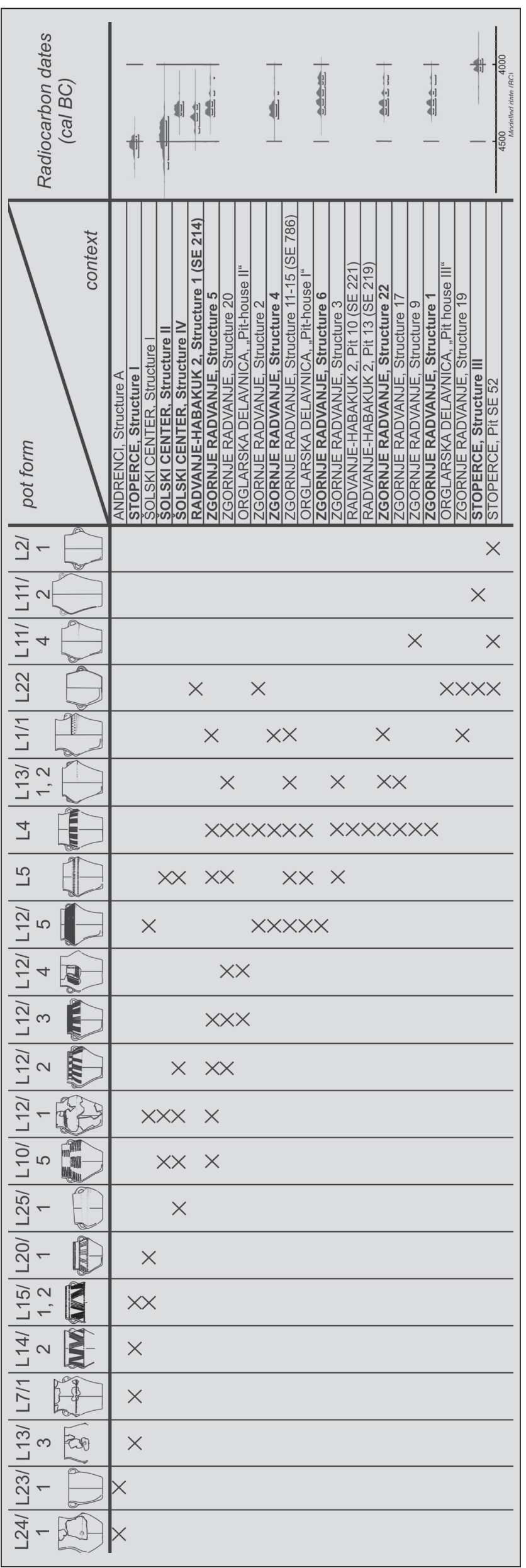

